\title{
Geophysical site survey results from North Pond (Mid-Atlantic Ridge) ${ }^{1}$
}

\author{
Friederike Schmidt-Schierhorn, ${ }^{2}$ Norbert Kaul, ${ }^{2}$ Sebastian Stephan, ${ }^{2}$ and Heinrich Villinger ${ }^{2}$
}

\section{Chapter contents}

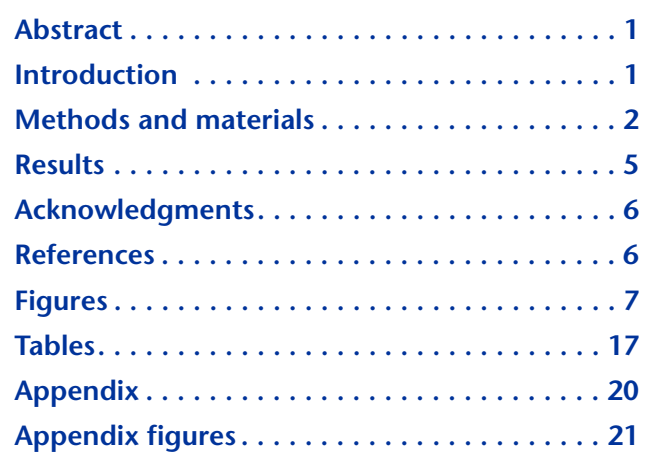

\footnotetext{
${ }^{1}$ Schmidt-Schierhorn, F., Kaul, N., Stephan, S., and Villinger, H., 2012. Geophysical site survey results from North Pond (Mid-Atlantic Ridge). In Edwards, K.J., Bach, W., Klaus, A., and the Expedition 336 Scientists, Proc. IODP, 336: Tokyo (Integrated Ocean Drilling Program Management International, Inc.). doi:10.2204/iodp.proc.336.107.2012 ${ }^{2}$ Department of Geosciences, University of Bremen, Postfach 330440, Bremen, Germany 28334. Correspondence author: vill@uni-bremen.de
}

\begin{abstract}
North Pond is an isolated small sediment pond $(8 \mathrm{~km} \times 14 \mathrm{~km})$ located on the western flank of the Mid-Atlantic Ridge $\left(23^{\circ} \mathrm{N}\right)$ that offers the opportunity to study microbial communities and their activities in deeply buried sediments and the underlying basement. North Pond has been previously studied by a series of Deep Sea Drilling Project and Ocean Drilling Program drill holes and seafloor observatories. However, the existing site survey data are not sufficient for the approved North Pond Integrated Ocean Drilling Program drilling expedition, scheduled to take place in 2011. Therefore, a site survey cruise on R/V Maria S. Merian (MSM 11/1) took place from 17 February through 12 March 2009 (Fort-deFrance, Martinique, to Dakar, Senegal) with the goal of mapping in detail the sediment/basement interface and increasing the heat flow measurement coverage.

A set of geophysical survey data was obtained comprising 14 lines $(238 \mathrm{~km})$ of multibeam data in combination with single-channel seismics and sediment echo-sounding, 61 successful heat flow measurements, and recovery of $68 \mathrm{~m}$ of cores. The survey confirms the existing results based on two seismic profiles from 1989, but the new data show the sediment/basement interface in much more detail. New heat flow measurements complement existing heat flow coverage and confirm the hydrothermal circulation pattern with inflow of cold seawater at the southern rim of the basin and upflow of warm water at the north-northwestern boundary. The new detailed geophysical data set will allow positioning the proposed drill holes and constrain hydrogeological modeling of the circulation in the upper crust.
\end{abstract}

\section{Introduction}

Thousands of sediment ponds exist on the flanks of mid-ocean ridges where depressions in the young oceanic crust serve as catchment areas for pelagic sediments. They have been studied for more than three decades because they are the only places close to the ridge crest where sediment cores contain temporal information on climate and magmatic events of the close-by ridge. These ponds also play a major role in the exchange processes between ocean and upper young crust because they act as barriers due to their very low permeability in comparison with the upper crust (Langseth et al., 1984). 
North Pond, located $140 \mathrm{~km}$ west of the Mid-Atlantic Ridge (Fig. F1) and $50 \mathrm{~km}$ south of the Kane Fracture Zone $\left(22^{\circ}-23^{\circ} \mathrm{N}, 46^{\circ} \mathrm{W}\right)$ in a water depth of $\sim 4300 \mathrm{~m}$, is probably the most investigated sediment pond in the world (Purdy et al., 1979). Its geochemistry, hydrology, and geologic setting have been studied intensively by a series of Deep Sea Drilling Program (DSDP) (Legs 45 and 78B) and Ocean Drilling Program (ODP) (Legs 109 and 174B) drill holes and seafloor observatories. The area of the roughly northeastsouthwest elongated pond (Fig. F2) is relatively small, with a size of $8 \mathrm{~km} \times 14 \mathrm{~km}$. Crustal age at the North Pond location is 7.3 Ma (Hussong et al., 1979).

During Leg 78B, downhole temperature logs in DSDP Hole 395A showed an almost isothermal temperature profile to $\sim 250$ meters below seafloor (mbsf) (Langseth et al., 1984). Downhole pressure measurements showed subhydrostatic pressures between 90 and $150 \mathrm{kPa}$ at 179 mbsf. Both observations were explained by Langseth et al. (1984) with a hydrogeological model (Fig. F3), where cold seawater enters the unsedimented basement (in the southeast) outside of the pond, warms up while flowing through the uppermost layers of oceanic basement (Layer 2A) beneath the pond, and escapes as warm water on the other side (northwest). This process results in subhydrostatic pressures in Hole 395A.

During a site survey cruise (Atlantis II 123-2, 1989) for a planned ODP drilling leg in North Pond, Langseth et al. (1992) measured seafloor heat flow within the pond. Their results show that the average heat flow at North Pond is only $20 \%-25 \%$ of the value calculated on the basis of a conductive lithospheric cooling model (Parsons and Sclater, 1977). Moreover, Langseth et al. (1992) found high heat flow in the northwestern part of the pond (near ODP Site 1074) and low values in the southeastern part (near Site 395). Their results are in good agreement with the data from Hussong et al. (1979) and with the suggested hydrogeological model that would also explain the overall low heat flow because this circulation transports heat out of the basement and thus increases cooling of the crust.

During Leg 174B, Hole 395A was equipped with an instrumented borehole seal, now known as a subseafloor borehole observatory (CORK) (Davis et al., 1992), and an additional hole (1074A) was drilled at the northwestern rim of the pond. A comprehensive overview of all investigations in North Pond is given by Becker et al. (2001). Oxidative weathering of oceanic crust occurs predominantly in the first 10$20 \mathrm{Ma}$ of its crustal age, and the role of microbial activity in these processes is still not clear (K. Edwards, pers. comm., 2009). Therefore, a group of microbiologists and geochemists submitted a drilling proposal to the Integrated Ocean Drilling Program (IODP) (K. Edwards et al., pers. comm., 2009) to address two key questions: (1) where do deep-seated microbial communities come from, and (2) what is the nature of microbial communities hosted in young ridge flanks and what is their role in ocean crust weathering? North Pond, with its established hydrothermal flow pattern in the upper crust, is a perfect place for investigations about the magnitude and activities of basement microbial communities.

In order to better define the geometry and the geothermal regime of North Pond, a geophysical site survey cruise took place on the German research vessel R/V Maria S. Merian (MSM11/1; 17 February12 March 2009). In addition, extensive sediment sampling with a gravity corer was undertaken to collect pore water and microbiological samples. The initially planned surveys could not be completed because the available working days were cut in half due to an accident on board. In particular, the geophysical survey of the southern part of North Pond is missing; therefore, we could not increase the heat flow coverage as originally planned. Moreover, additional seismic lines with a different source and different orientation of the profiles had to be skipped. However, sufficiently dense coverage with geophysical data enabled us to position the planned drill holes within the pond, and the collected cores allow assessing basic (bio)geochemical and microbial processes within the sediments. The goal of this report is to present all geophysical methods used and results in detail.

\section{Methods and materials}

\section{Navigation}

Navigation of the ship was achieved with differential GPS, resulting in an absolute accuracy of the ship position on the order of $\pm 5 \mathrm{~m}$. During station work, especially during heat flow measurements, the ship uses its dynamic positioning system together with the propulsion of two azimuth thrusters and a pump-jet, which makes navigation easy and very precise. The exact position of the heat probe was measured with a transponder and a Posidonia system, strapped $\sim 50 \mathrm{~m}$ above the probe onto the wire.

\section{Acoustic surveys}

The goal of the acoustic surveys was (1) to map the bathymetry of the pond and the adjacent areas, (2) to investigate the upper 50-100 m of the sediment fill in detail, and (3) to map the sediment/basement interface. Since these acoustic surveys use different source frequency, they provide geological information of different depth with different resolution. 


\section{Bathymetric survey}

For deep-sea bathymetric surveys, the ship provides a hull-mounted Kongsberg EM 120 system with 191 beams and a main operating frequency of $12 \mathrm{kHz}$. Opening angles of the emission beam can be up to $130^{\circ}$ across-track, whereas it is fixed to $2^{\circ}$ along-track. Spacing of the beams can be set up either equiangular or equidistant. The absolute water depth was calculated with a sound velocity profile (obtained by a conductivity, temperature, and depth measurement) and the two-way traveltime for each beam. Significant accuracy of the measurement was achieved by using a combination of phase for the central beams and amplitude for the lateral beams.

Processing of the data such as outlier elimination and interpolation of the depth data on a grid was done using Neptune software (Kongsberg). Generic mapping tools (GMT) (gmt.soest.hawaii.edu/) were used to produce a map of the area by combining the new bathymetric data with that already existing, which has a much lower spatial resolution. This "old" data set was obtained during Cruise Conrad 30-01 in 1989 (Co-Chief Scientists R. Detrick and J. Mutter) and is available from www.marine-geo.org/tools/ search/entry.php?id=RC3001 (2 February 2012).

\section{Parasound profiles}

For subbottom profiling, the permanently installed hull-mounted Atlas Parasound P70 system (www.ifm.zmaw.de/fileadmin/files/leitstelle/merian/ MSM_HandbuchParasound.pdf, 2 February 2012) was used to map the upper sections of the sediment body. These surveys were very important in finding suitable sites for sediment sampling with a gravity corer and deployments of the heat flow lance. The system uses a combination of a low-frequency sediment echo sounder and a high-frequency narrow beam sounder for detection of water depth. It is operated in parametric mode with a secondary frequency of $3.8 \mathrm{kHz}$. The advantage of using a parametric system is that its footprint size is only $7 \%$ of the water depth, which is much smaller compared to conventional sediment echo sounding systems. The Atlas Parasound P70 system can reach penetration depths of up to $200 \mathrm{~m}$. It was operated at intervals of $400 \mathrm{~ms}$ between pulses, resulting in a spatial resolution of $2-3 \mathrm{~m}$ at a ship speed of $5 \mathrm{kt}$. An echogram was recorded every second.

Postprocessing of these data was done using Atlas Parastore software for replays and the seismic data processing package Vista Seismic Processing 7.0. First processing procedures were conducted on board with a wide bandpass filter to improve the signal-tonoise ratio and amplification of the deeper and weaker reflections by normalization to a constant value. Further processing and description of the results was summarized in a Bachelor thesis by U. Beckert (2009) from the University of Bremen.

\section{Seismic survey}

To profile the deeper subbottom and to detect the interface between sediment and basement, a generatorinjector (GI) gun and a streamer with hydrophones were used. During the cruise, operations were conducted in "true GI mode," where the generator's original volume of $1.7 \mathrm{~L}\left(105 \mathrm{in}^{3}\right)$ is reduced to $0.7 \mathrm{~L}$ $\left(45 \mathrm{in}^{3}\right)$, which is the optimal configuration for totally suppressing bubble oscillations. The overall air consumption therefore amounted to $2.4 \mathrm{~L}\left(150 \mathrm{in}^{3}\right)$. Compressed air was provided by a mobile LMF (Leobersdorfer Maschinenfabrik AG, Austria) compressor with an actual pressure at the gun port of 200 bar.

The trigger signal was supplied to the generator and the injector from the homemade "TriBo" triggerbox system containing a high-precision quartz time base. The air gun was towed $10-15 \mathrm{~m}$ behind the vessel at a water depth of 5-6 m. The best results for this source depth were achieved using a delay time of $35 \mathrm{~ms}$ between generator and injector.

The seismic signals were received with a $101 \mathrm{~m}$ active length Teledyne streamer with 16 channels towed $\sim 150 \mathrm{~m}$ behind the ship. Each channel (group) consists of eight hydrophones with one group forming a $6.25 \mathrm{~m}$ long unit. Analog to digital (A/D) conversion and acquisition of the data were achieved with a combination of the National Instruments NI SCXI-100 A/D converter system and a homemade seismic recording system built at the Department of Geosciences, University of Bremen. The data were recorded at a sample interval of $0.25 \mathrm{~ms}$, a record length of $5 \mathrm{~s}$, and a water delay of $3 \mathrm{~s}$. An antialiasing filter at $2500 \mathrm{~Hz}$ filtered the incoming data. On board the ship, preliminary processing was accomplished with GEDCO VISTA VW Processing 3D (version 7.029) software. The 16 channels were stacked and time-migrated with a constant velocity of $1500 \mathrm{~m} / \mathrm{s}$. An Ormsby bandpass filter (frequencies $=20 / 25-200 / 220$ ) was applied to remove noise. The WinGeoapp software (created by H. Keil, Department of Geosciences, University of Bremen) used information from the header data (recording time, shotpoint number) and on the geometry of the system streamer-gun-GPS antenna to calculate locations for the common midpoints of the shot gather. Also, the amplitude scale was adjusted manually, and automatic gain control scaling and exponential gain were set. Sediment thicknesses, determined from the interface between sediment and basement, were picked using VISTA. 


\section{Seafloor heat flow measurements}

During the cruise we exclusively used the $6 \mathrm{~m}$ long Bremen heat flow probe, also called the Giant Heat Flow Probe. The mechanically robust heat probe is designed for operation in pogo-style mode, with a wide application ranging from $6000 \mathrm{~m}$ deep-sea trenches with mostly soft sediments to the upper continental slope, where sediments are often sandy and difficult to penetrate. Because of the $6 \mathrm{~m}$ length of its temperature sensor string, undisturbed temperature gradients can be determined even in shallow water where seasonal bottom water temperature variations are superimposed on the undisturbed temperature field close to the seafloor.

The heat probe (Fig. F4) is constructed in the classical "violin bow" design (Hyndman et al., 1979; Hartmann and Villinger, 2002), with 22 thermistors distributed over a total length of $6 \mathrm{~m}$ at $0.27 \mathrm{~m}$ intervals mounted inside an oil-filled hydraulic tube (outer diameter $[\mathrm{OD}]=14 \mathrm{~mm}$ ), which is attached to the strength member $(\mathrm{OD}=130 \mathrm{~mm})$. The sensor tube also contains a heater wire for the generation of high-energy heat pulses, typically $>300 \mathrm{~W}$ for in situ thermal conductivity measurements (Lister, 1979). Only noncorrosive steel was used for the heat probe, with special high-strength noncorrosive steel for the strength member and the fins attaching the sensor tube to it.

The complete data acquisition unit, including power supply, is housed in a single $110 \mathrm{~mm}$ OD $\times 300 \mathrm{~mm}$ long titanium pressure case and mounted inside the probe's weight stand. A second pressure case of the same size houses the batteries for heat pulses.

The signal of the temperature sensors is measured with a resolution of 20 bits at a sample interval of $1 \mathrm{~s}$, resulting in a final temperature resolution of better than $1 \mathrm{mK}$ at ambient seafloor temperatures. A calibrated PT-100 seawater sensor on top of the weight stand allows measuring the absolute bottom water temperature and checking the calibration of the sensor string in deep water. Inclination and acceleration of the probe are also measured at a $1 \mathrm{~s}$ sample interval to monitor the penetration process into the sediments and potential disturbances during the measurement period while the probe sits in the sediment. The complete data set is stored in the probe but is also transmitted via coax cable on board in real time, where the data are visualized and stored on a PC. In that way, the operator always has complete control of the instrument, allowing operational decisions during deployments of the probe. In addition, the heat probe can be operated in a completely autonomous mode with internal data storage and automated heat pulses if a coax cable is not available. The battery capacity allows for 3 days of continuous operation in pogo-style mode.
Winch speed during pay-out and retrieval is $1.0 \mathrm{~m} / \mathrm{s}$, which guarantees full penetration in the sediments of this working area. Time to equilibrate to in situ temperatures is assumed to be 7-8 min; time for heat pulse decay observation takes an additional $8 \mathrm{~min}$. The mean duration of one measurement, including transit, is $\sim 1-1.5 \mathrm{~h}$ per single point of measurement.

Penetration of the heat probe into the upper meters of the soft sediments generates a thermal disturbance due to frictional heating, and in addition, the sensor string has to come into thermal equilibrium with the sediments. This means that the probe stays in the sediment for $10 \mathrm{~min}$; however, it will not have fully equilibrated after this time. Therefore, the temperature decay has to be fitted to a theoretical decay model. In situ thermal conductivity is measured with the heat pulse method (Lister, 1979), where the sensor string is heated for typically 20$30 \mathrm{~s}$ and thermal conductivity is derived from the temperature decay. Both frictional and heat pulse decay can be described by the same mathematical model. The basic processing steps of heat flow measurements are outlined in Hyndman et al. (1979), which was a manual procedure based on the work of Lister (1970, 1979). The theoretical background for the analysis of heat flow measurements is discussed in Bullard (1954), Lister (1970), Hyndman et al. (1979), Villinger and Davis (1987), and Hartmann and Villinger (2002). To overcome deficiencies of the processing routine described in Villinger and Davis (1987) and to incorporate platform-independent plotting routines, a mathematically sound inversion scheme of observed temperature decays was implemented in a program.

\section{Physical properties measurements on cores}

During the cruise, we took gravity cores for pore water geochemistry sampling and porosity measurements on samples, but we also measured thermal conductivity and electrical resistivity on split cores. Thermal conductivity measurements were made on archive halves with a commercially available thermal conductivity instrument KD2PRO (www.decagon.com, 2 February 2012), which is based on the needle probe method. The needle used is $60 \mathrm{~mm}$ long with $\mathrm{OD}=1$ $\mathrm{mm}$. According to specifications, the resulting thermal conductivity had an absolute accuracy of $5 \%$. The split cores were measured after they equilibrated to ambient temperatures in the laboratory. If possible, measurements were made every $25 \mathrm{~cm}$.

Measurements of porosity, thermal conductivity, and electrical resistivity were obtained onshore in the European Consortium for Ocean Research Drilling (ECORD) laboratories of the Center for Marine Environmental Sciences (MARUM; Bremen, Germany) 
with the multisensor core logger (MSCL; in Hellman, 2009).

\section{Results}

A set of geophysical survey data was obtained during 6 working days containing 14 lines of multibeam data in combination with single-channel seismics and sediment echo-sounding, 5 heat flow surveys with 61 successful measurements, and physical properties measurements on cores such as thermal conductivity, electrical resistivity, and porosity.

\section{Bathymetry}

The EM120 was turned on during all our operations. Therefore, we were able to generate an improved bathymetric chart of North Pond compared to the existing one from 1989 (Atlantis II 123-2 cruise). The resulting map is shown in Figure F2, whereas Figure F5 shows a map which also contains seismic and Parasound lines together with the associated shotpoints.

The bathymetry shows North Pond as an ellipsoidal feature with a main direction of southwest-northeast. The water depth is, from the flanks to the innermost sections, between 4000 and $4500 \mathrm{~m}$. A ridge is located in the northwestern part of the pond, which extends into the pond; ODP Site 1074 is located at its southernmost end. A separate small basin within the pond containing two mounds is located in the northeast part, and another mound is in the east of the pond. The surrounding steep flanks probably supply a large amount of the deposited sediment, which was also confirmed by the existence of turbidity flow structures in sediment cores from Site 395 (Melson, Rabinowitz, et al., 1979; Hyndman, Salisbury, et al., 1984; Beckert, 2009).

\section{Seismic and sediment echo-sounding survey}

The profiles running from southwest to northeast (Profiles 1-11) range between 18.2 and $19.6 \mathrm{~km}$ in length (except Parasound Profile 3, which is $10.3 \mathrm{~km}$ long). Perpendicular to these, Profiles 12-14 are shorter, with lengths between 11.3 and $11.9 \mathrm{~km}$. An overview of the location of the seismic profiles is shown in Figure F5. All seismic and Parasound profiles, including navigation track charts, can be found in the "Appendix."

The sediment echo-sounding (Parasound) system was able to penetrate the seafloor as deep as $80 \mathrm{~m}$ in the central basin (e.g., Fig. F6), whereas it was difficult to image the sediments close to the flanks of the pond because of strong diffractions and side echoes.
These diffractions and echoes also made it impossible to locate the exact boundary between bare rock and sediments (Fig. F6) at the edges of the basin. Data within the basin show well-layered sediment packages, resolving layers with a thickness of several decimeters.

In general, the seismic measurements image the sediment/basement boundary quite well; however, the clear image is masked in some locations and especially at the boundary of the pond by side echoes and hyperbolas because of rough basement topography. An example is given with Profile 10 in Figure F7. In the northeast, between Shotpoints 7614 and 7514 (Fig. F7), the basement seems to outcrop. This is in good agreement with the bathymetric map showing a shallower section and two mounds lying in the northeastern part of North Pond.

\section{Heat flow}

Overall, 61 heat flow measurements on 5 profiles were obtained during the cruise (Fig. F5). Two of the profiles (HF-1 and HF-5) run from southwest to northeast; the rest were obtained from southeast to northwest. All of them are located on multibeam and seismic profiles.

An example of a successful heat flow measurement is shown in Figure F8. Figure F8A shows the temperature increase with depth at a calculated temperature gradient of $16.5 \mathrm{~K} / \mathrm{km}$. Thermal conductivity increases slightly with depth with small-scale fluctuations around the mean value of $0.99 \mathrm{~W} /(\mathrm{m} \cdot \mathrm{K})$ (Fig. F8B; red dashed line). These can either be due to the accuracy of the needle probe or caused by turbidity layers originating from the flanks of the pond. As we do not have enough cores in the vicinity, these assumptions cannot be proven. Figure F8C shows the Bullard depth (Bullard, 1954), which is defined as the thermal resistivity versus temperature.

All heat flow values are summarized in Tables T1, T2, T3, T4, and T5. An overview of heat flow values at North Pond is shown in Figure F9, together with the results of Langseth et al. (1992). The measurements from Cruise MSM 11/1 confirm the results obtained two decades ago.

The heat flow survey was supposed to complete the coverage of North Pond, but due to the reduced number of working days during the cruise, measurements are still lacking in the southwest of North Pond.

\section{Coring results and physical properties}

During Cruise MSM11/1, 14 gravity cores (3-12 m long) were obtained from the sediments (GeoB13501GeoB13514). Location and core recovery are shown in Table T6. 
In situ thermal conductivity agrees very well with measurements on cores but also with the data published by Langseth et al. (1992) (Fig. F10). All other results of physical properties measurements can be found in the Pangaea database (www.pangaea.de).

\section{Acknowledgments}

We would like to thank Captain Klaus Bergmann, his mates, and the crew of the Maria S. Merian for their tremendous support of our scientific program and for hosting us so friendly on board. We are especially thankful for the prolongation of the cruise, granted by the Senatskommission für Ozeanographie and many thanks to the chief scientist and science party of MSM11/2 for the generous "gift" of two additional working days. The ship time of Maria S. Merian was provided by the Deutsche Forschungsgemeinschaft within the core program of METEOR/MERIAN. The participation of the US scientists on board was made possible by funding from the National Science Foundation. We gratefully acknowledge all this support.

\section{References}

Becker, K., Bartetzko, A., and Davis, E.E., 2001. Leg 174B synopsis: revisiting Hole 395A for logging and long-term monitoring of off-axis hydrothermal processes in young oceanic crust. In Becker, K., and Malone, M.J. (Eds.), Proc. ODP, Sci. Results, 174B: College Station, TX (Ocean Drilling Program), 1-12. doi:10.2973/ odp.proc.sr.174B.130.2001

Beckert, U., 2009. Parasound data from "North Pond," Mid-Atlantic Ridge. Supplement to Auswertung und interpretation von parasound-daten aus "North Pond," Mittelatlantischer Rücken [B.S. thesis]. Univ. of Bremen. doi:10.1594/PANGAEA.778514

Bullard, E.C., 1954. The flow of heat through the floor of the Atlantic Ocean. Proc. R. Soc. London, Ser. A, 222(1150):408-429. doi:10.1098/rspa.1954.0085

Davis, E.E., Becker, K., Pettigrew, T., Carson, B., and MacDonald, R., 1992. CORK: a hydrologic seal and downhole observatory for deep-ocean boreholes. In Davis, E.E., Mottl, M.J., Fisher, A.T., et al., Proc. ODP, Init. Repts., 139: College Station, TX (Ocean Drilling Program), 43-53. doi:10.2973/odp.proc.ir.139.103.1992

Hartmann, A., and Villinger, H., 2002. Inversion of marine heat flow measurements by expansion of the temperature decay function. Geophys. J. Int., 148(3):628-636. doi:10.1046/j.1365-246X.2002.01600.x

Hellman, D., 2009. Geophysical measurements on sediment cores from North Pond, Mid-Atlantic Ridge [B.S. thesis]. Univ. of Bremen. doi:10.1594/PANGAEA.776875
Hussong, D.M., Fryer, P.B., Tuthill, J.D., and Wipperman, L.K., 1979. The geological and geophysical setting near DSDP Site 395, North Atlantic Ocean. In Melson, W.G., Rabinowitz, P.D., et al., Init. Repts. DSDP, 45: Washington, DC (U.S. Govt. Printing Office), 23-37. doi:10.2973/dsdp.proc.45.102.1979

Hyndman, R.D., Davis, E.E., and Wright, J.A., 1979. The measurement of marine geothermal heat flow by a multipenetration probe with digital acoustic telemetry and in situ thermal conductivity. Mar. Geophys. Res., 4(2):181-205. doi:10.1007/BF00286404

Hyndman, R.D., Salisbury, M.H., et al., 1984. Init. Repts. DSDP, 78B: Washington, DC (U.S. Govt. Printing Office). doi:10.2973/dsdp.proc.78b.1984

Langseth, M.G., Becker, K., Von Herzen, R.P., and Schultheiss, P., 1992. Heat and fluid flux through the sediment on the western flank of the Mid-Atlantic Ridge: a hydrogeological study of North Pond. Geophys. Res. Lett., 19(5):517-520. doi:10.1029/92GL00079

Langseth, M.G., Hyndman, R., Becker, K., Hickman, S.H., and Salisbury, M., 1984. The hydrogeological regime of isolated sediment ponds in mid-oceanic ridges. In Hyndman, R.D., Salisbury, M.H., et al., Init. Repts. DSDP, 78B: Washington, DC (U.S. Govt. Printing Office), 825837. doi:10.2973/dsdp.proc.78b.117.1984

Lister, C.R.B., 1970. Measurement of in situ sediment conductivity by means of a Bullard-type probe. Geophys. J. R. Astron. Soc., 19(5):521-532. doi:10.1111/j.1365246X.1970.tb00157.X

Lister, C.R.B., 1979. The pulse-probe method of conductivity measurement. Geophys. J. R. Astron. Soc., 57(2):451461. doi:10.1111/j.1365-246X.1979.tb04788.x

Melson, W.G., Rabinowitz, P.D., et al., 1979. Init. Repts. DSDP, 45: Washington, DC (U.S. Govt. Printing Office). doi:10.2973/dsdp.proc.45.1979

Parsons, B., and Sclater, J.G., 1977. An analysis of the variation of ocean floor bathymetry and heat flow with age. J. Geophys. Res., [Solid Earth], 82(5):803-827. doi:10.1029/JB082i005p00803

Purdy, G.M., Schouten, H., Crowe, J., Barrett, D.L., Falconer, R.K.H., Udintsev, G.B., Marova, N.A., Litvin, V.M., Valyashko, G.M., Markushevich, V.M., and Zdorovenin, V.V., 1979. IPOD Survey Area AT-6: a site survey. In Melson, W.G., Rabinowitz, P., et al., Init. Repts. DSDP, 45: Washington, DC (U.S. Govt. Printing Office), 39-48. doi:10.2973/dsdp.proc.45.103.1979

Villinger, H., and Davis, E.E., 1987. A new reduction algorithm for marine heat flow measurements. J. Geophys. Res., [Solid Earth], 92(B12):12846-12856. doi:10.1029/ JB092iB12p12846

Publication: 16 November 2012 MS 336-107 
Figure F1. Map showing the location of North Pond on the western flank of the Mid-Atlantic Ridge, south of the Kane Fracture Zone.

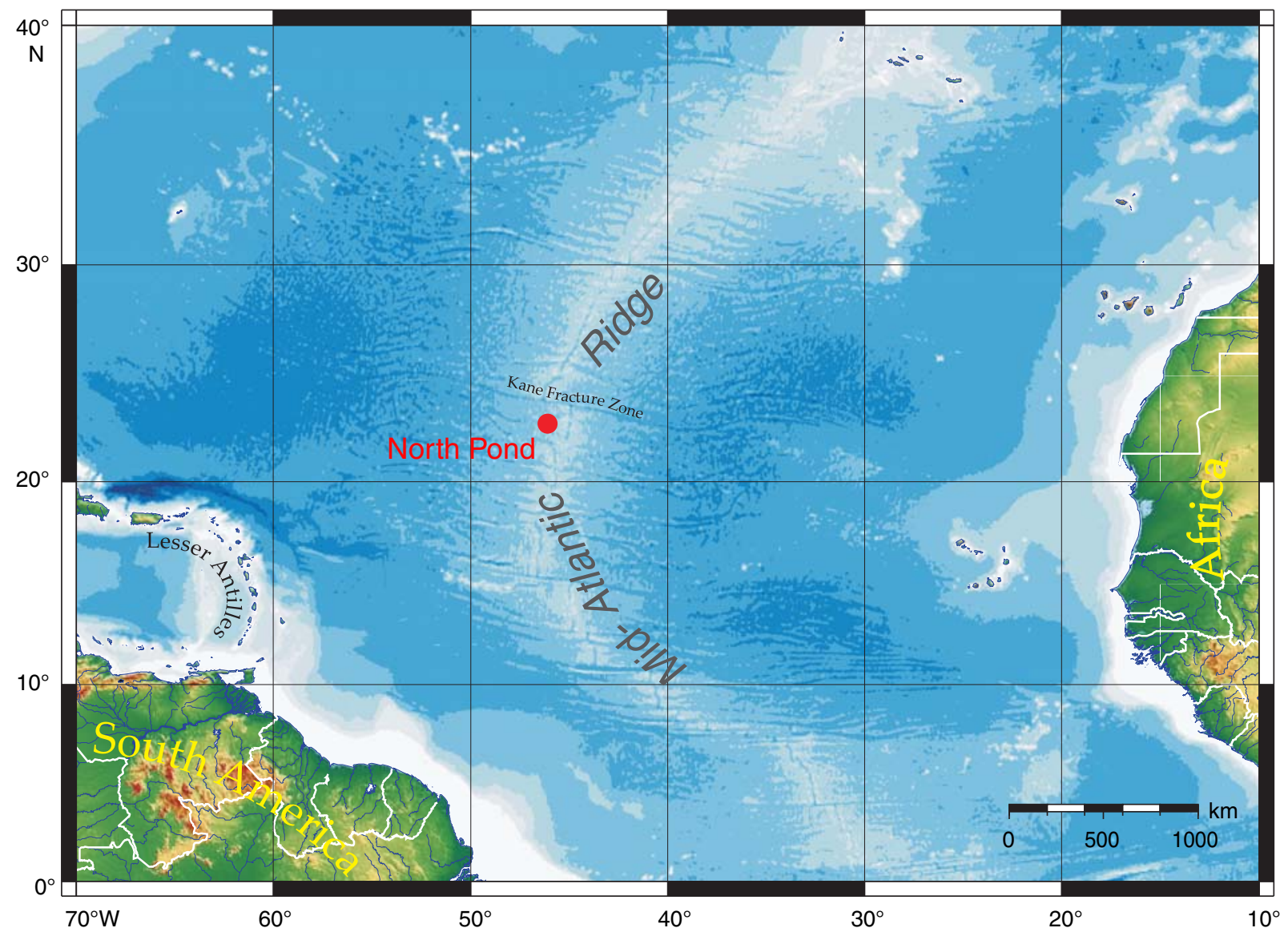


Figure F2. Map of North Pond containing bathymetric data from Cruise MSM 11/1. Stars = five drill holes from DSDP (Site 395), ODP (Site 1074), and IODP (Sites U1382, U1383, and U1384).

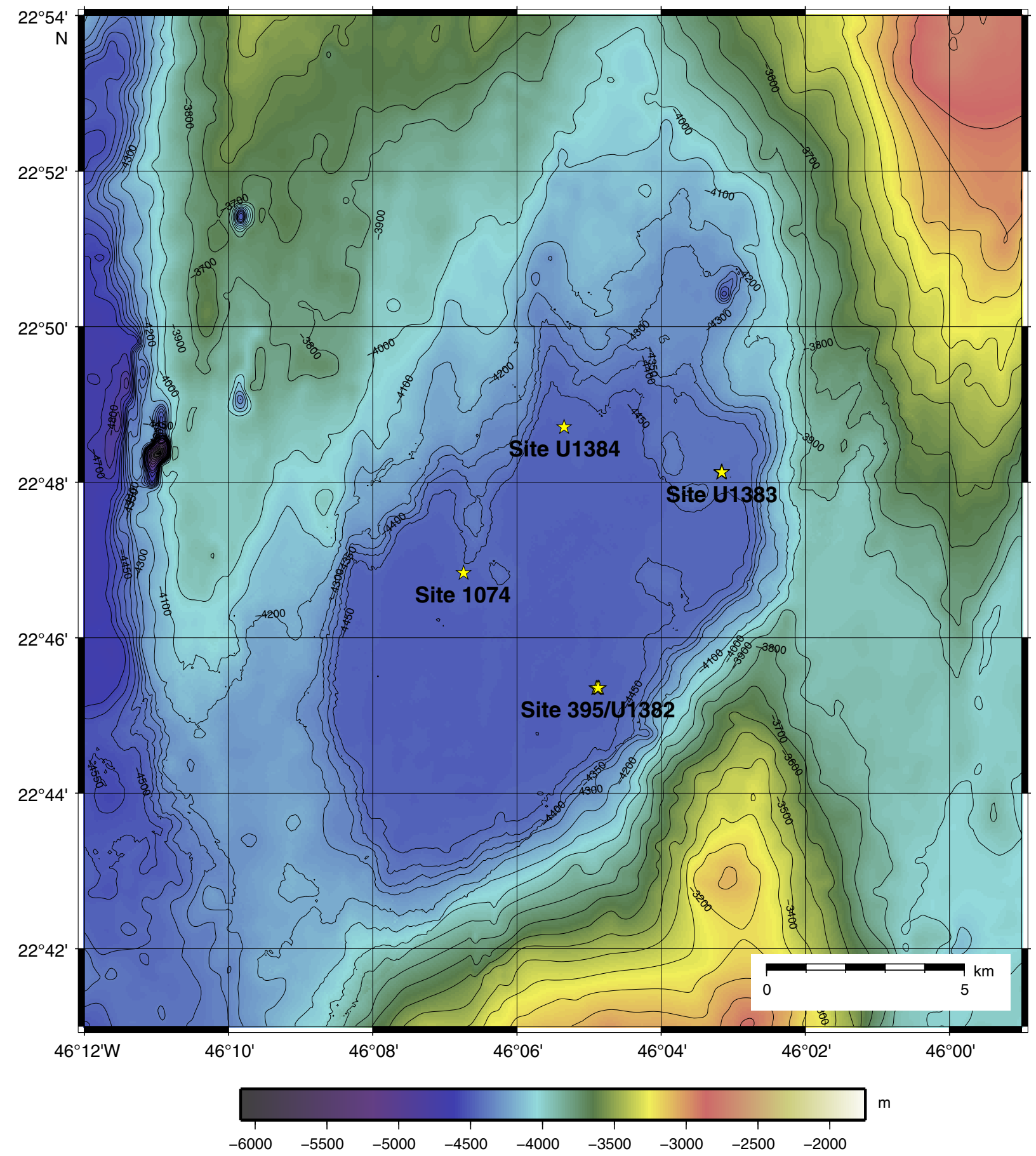


Figure F3. Model after Langseth et al. (1992) showing hypothesized hydrothermal circulation in the basement. Cold fluids flowing down on the southeastern flank warm up while flowing beneath the mostly impermeable sediment layers and escape in the northwestern part of the pond. This could be the reason for the overall low heat flow values in the area, as the circulation is transporting heat out of the system.

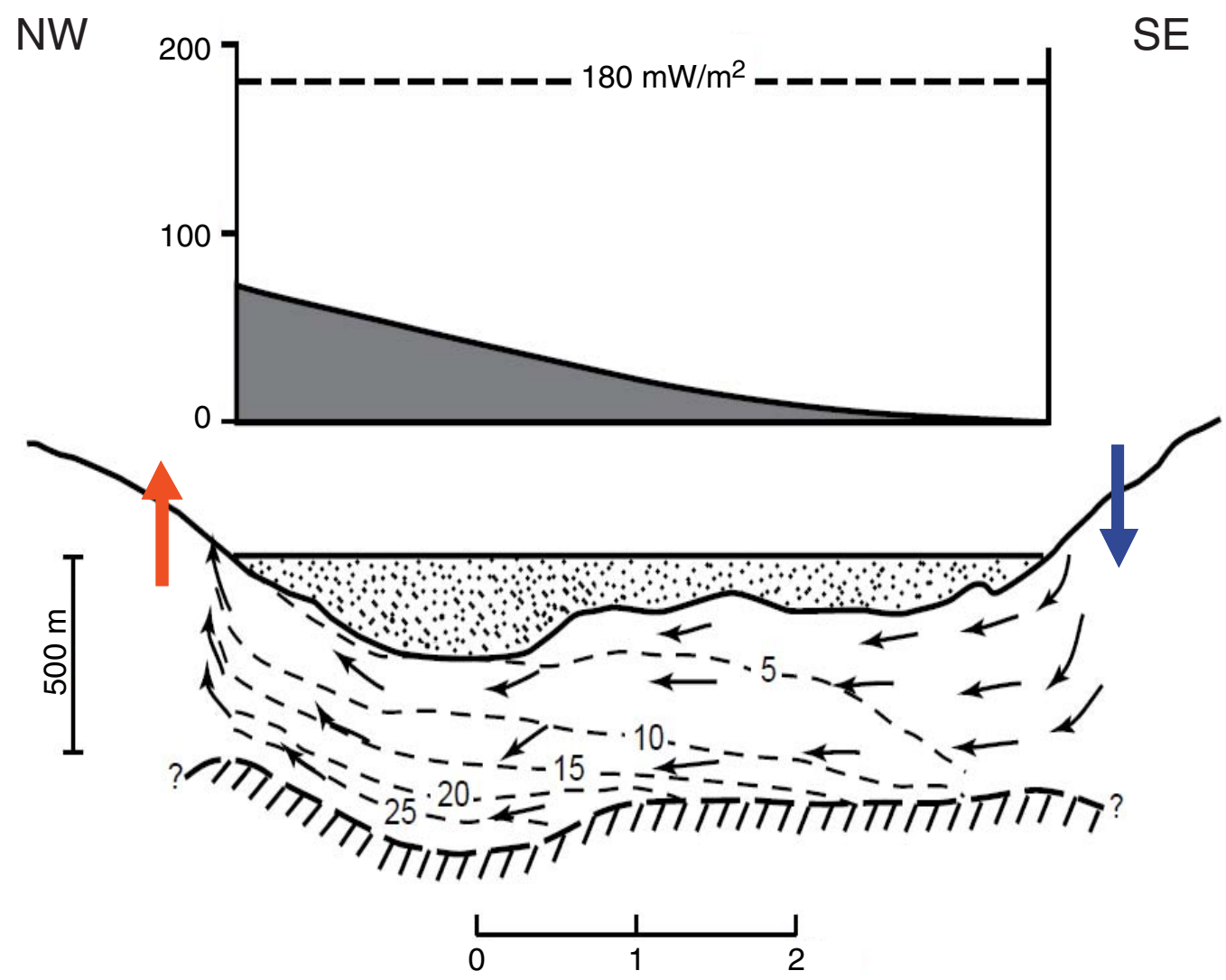


Figure F4. Schematic of heat flow lance with its major elements: weight stand, strength member, and sensor string (after Hartmann and Villinger, 2002).

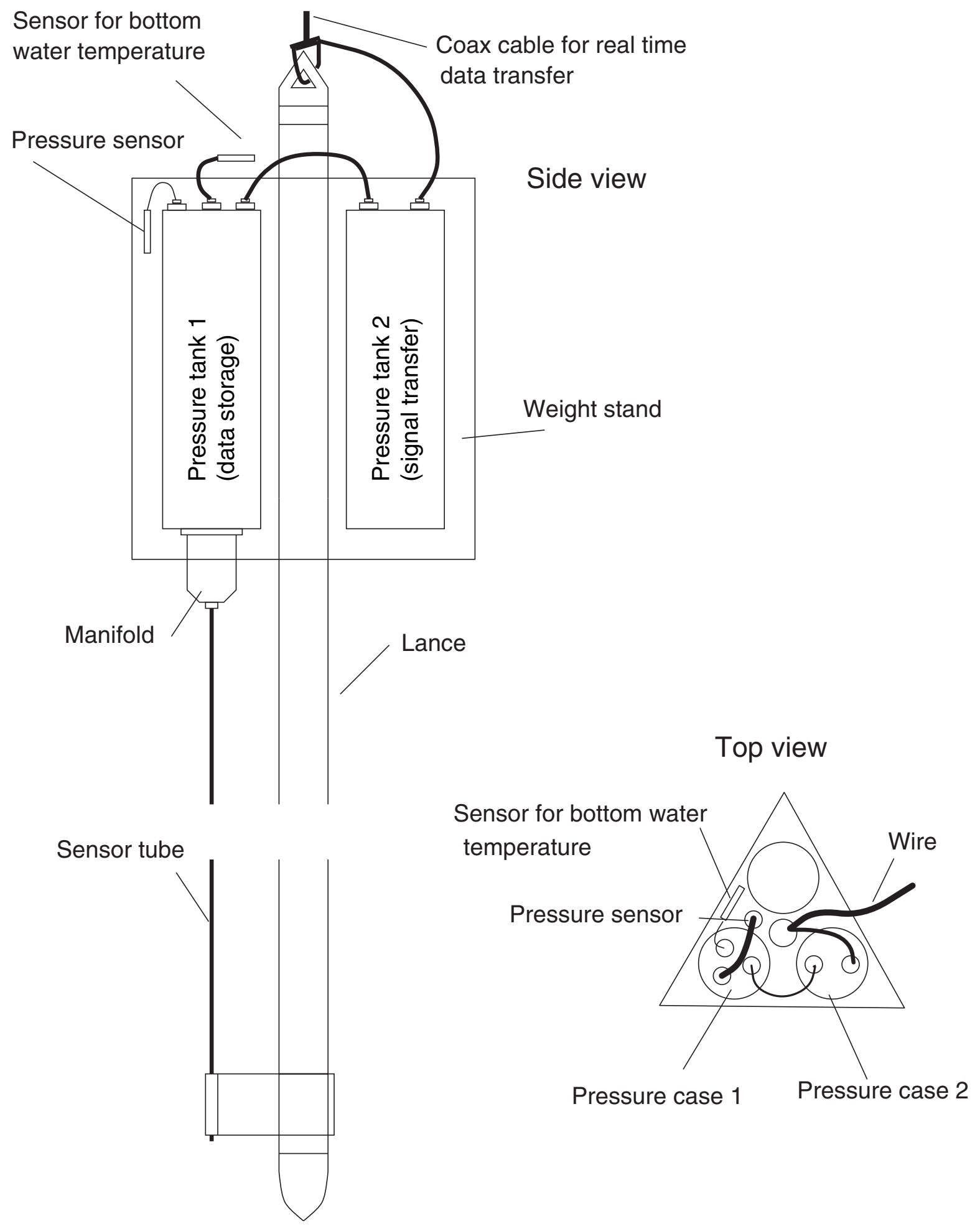


Figure F5. Survey track lines (black = profile numbers) with multibeam, Parasound, and seismic data; core locations; and heat flow profiles (HF-1 to HF-5). Profiles HF-1 and HF-5 were obtained from southwest to northeast and are aligned with multibeam Profiles 11 and 5, respectively. HF-2-HF-4 run from southeast to northwest and lie on multibeam Profiles 13, 12 and 14, respectively. Diamonds = individual heat flow measurements (see Tables T1, T2, T3, T4, and T5 for detailed summary of heat flow profiles). Circles = gravity core locations (see Table T6 for details of cores taken). Stars = positions of DSDP, ODP, and IODP boreholes.

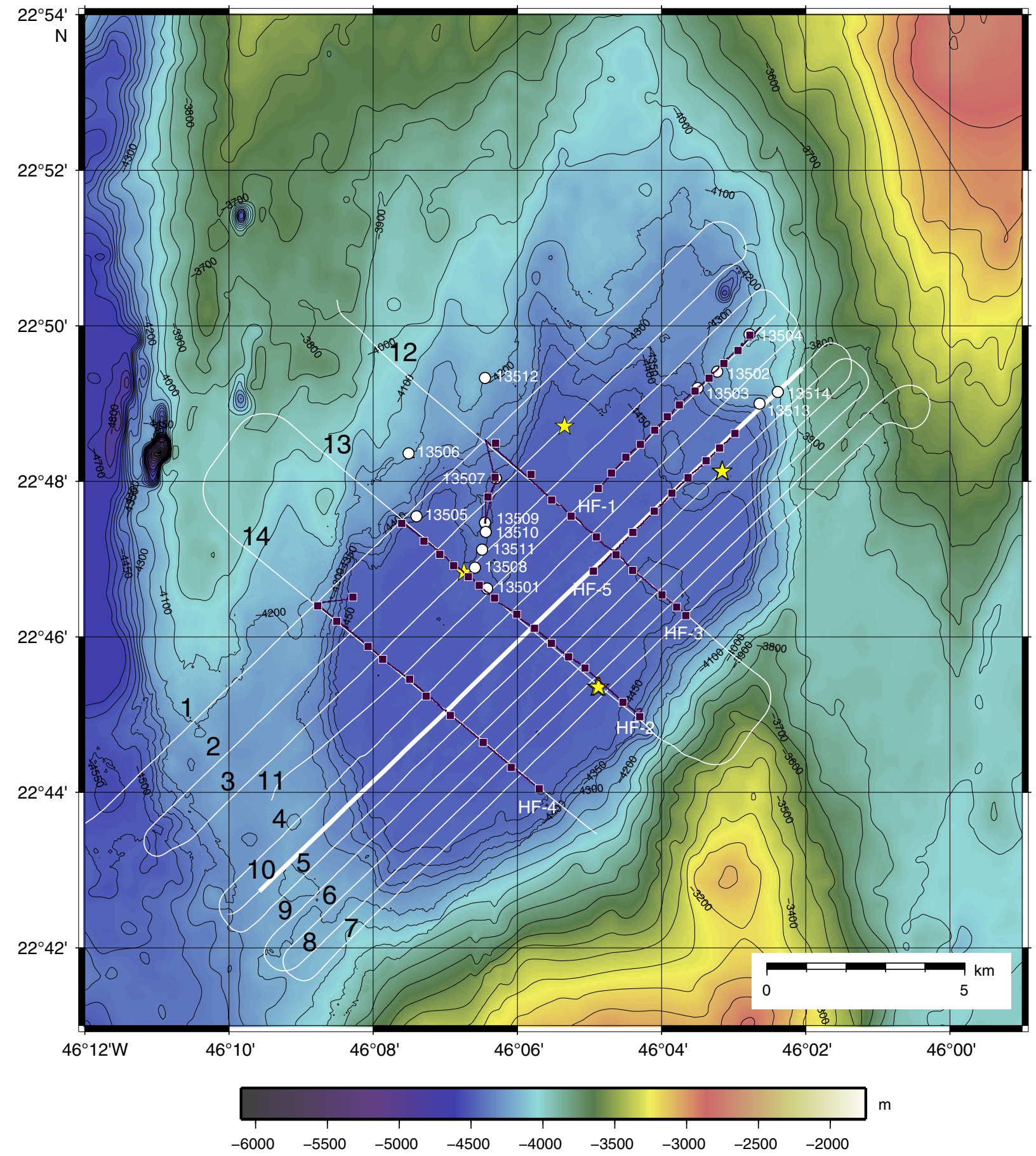


Figure F6. Parasound Profile 10. See Figure F5 for profile location (bold white line). Vertical exaggeration $=\sim 80$.

Echo amplitudes, scale factor: 450.0

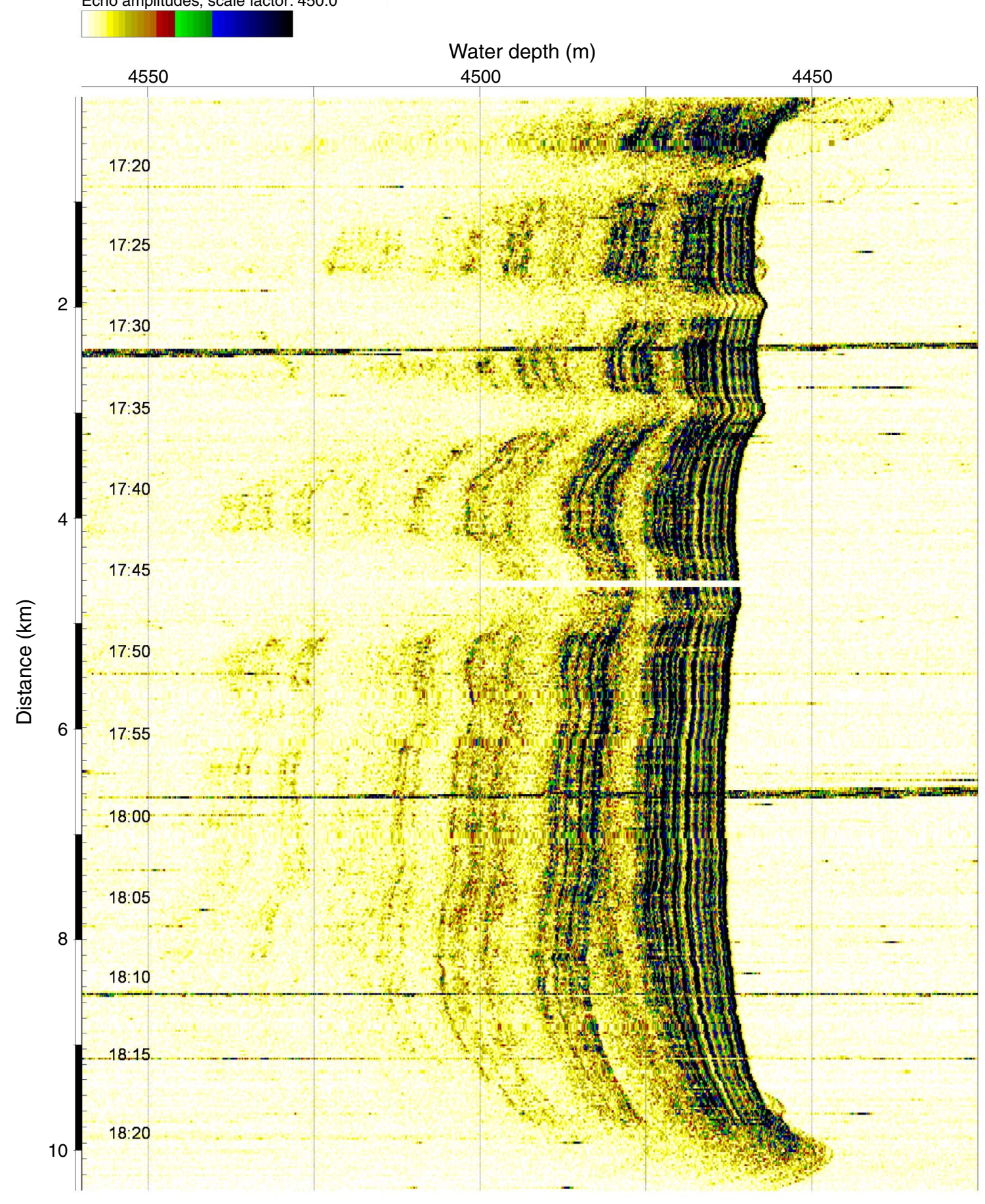


Figure F7. Seismic Profile 10. Channel $=16$. See Figure F5 for profile location (bold white line). Vertical exaggeration $=\sim 23.5$.

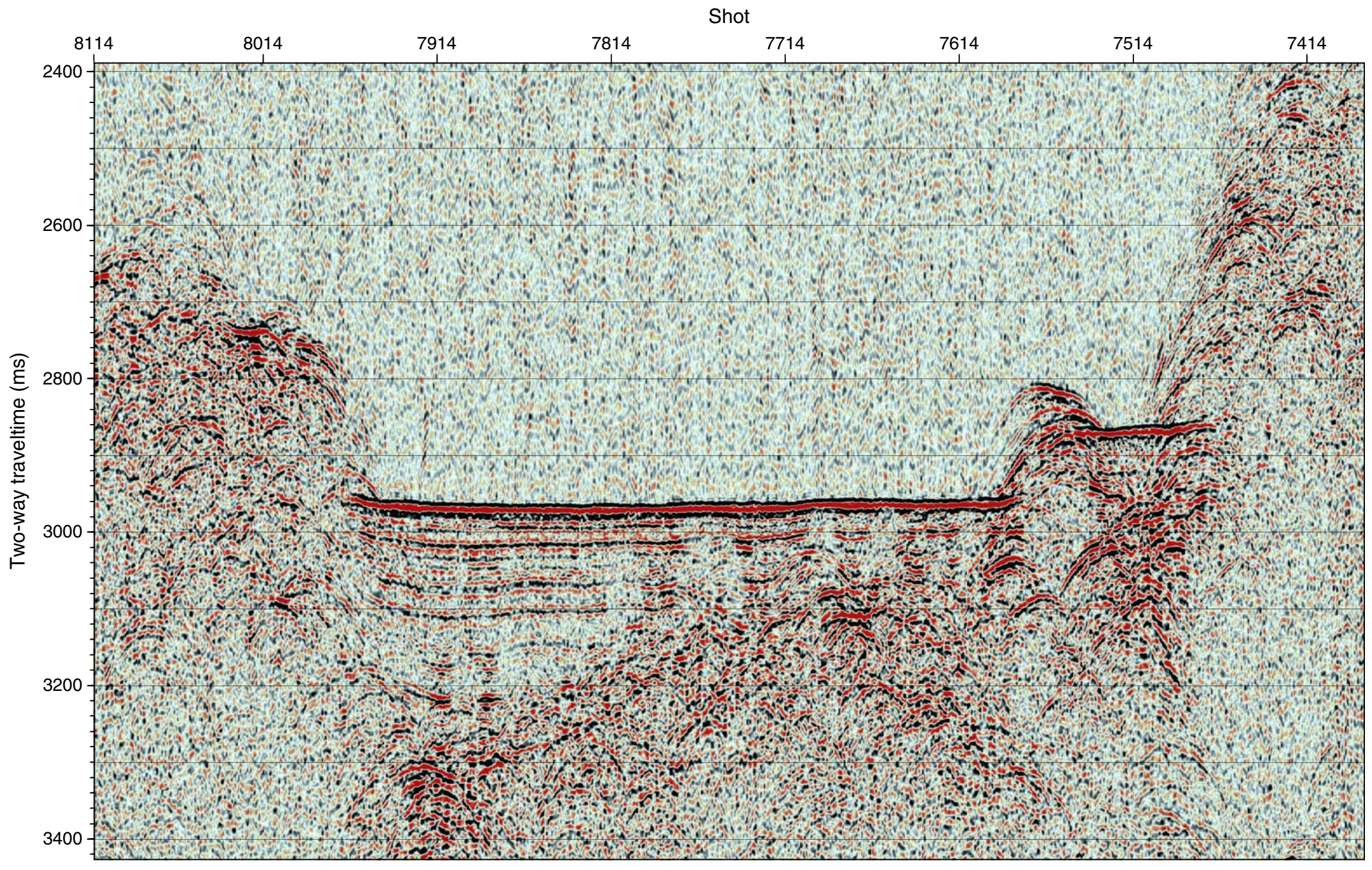


Figure F8. Example of a heat flow measurement result. A. Thermal gradient with depth. B. Thermal conductivity vs. depth. C. Bullard plot (Bullard, 1954); temperature vs. thermal resistance.

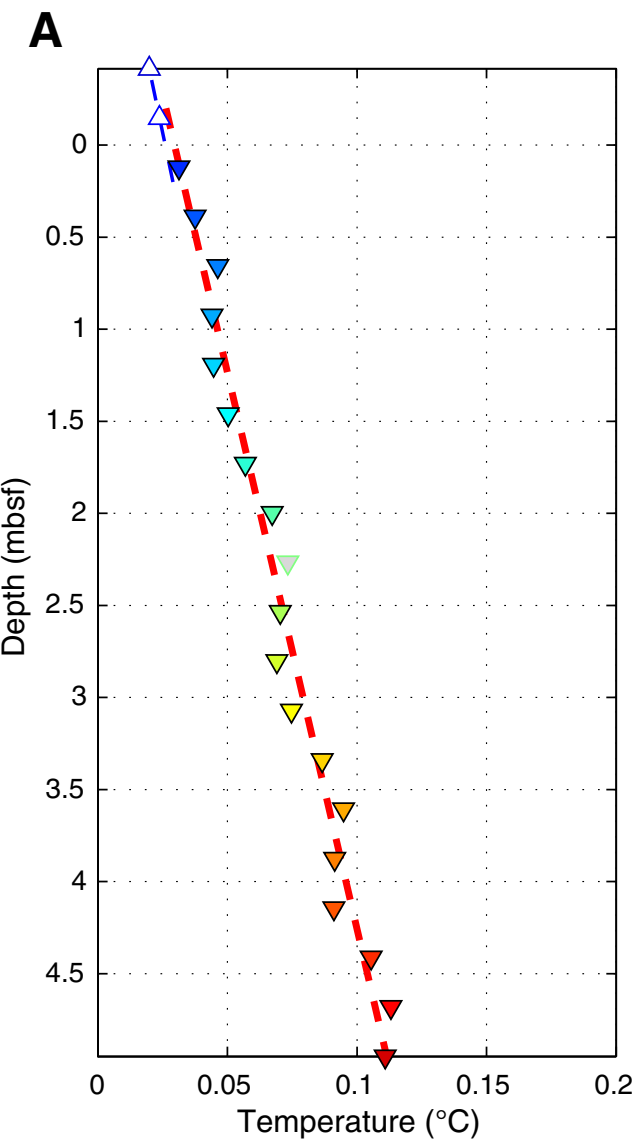

B

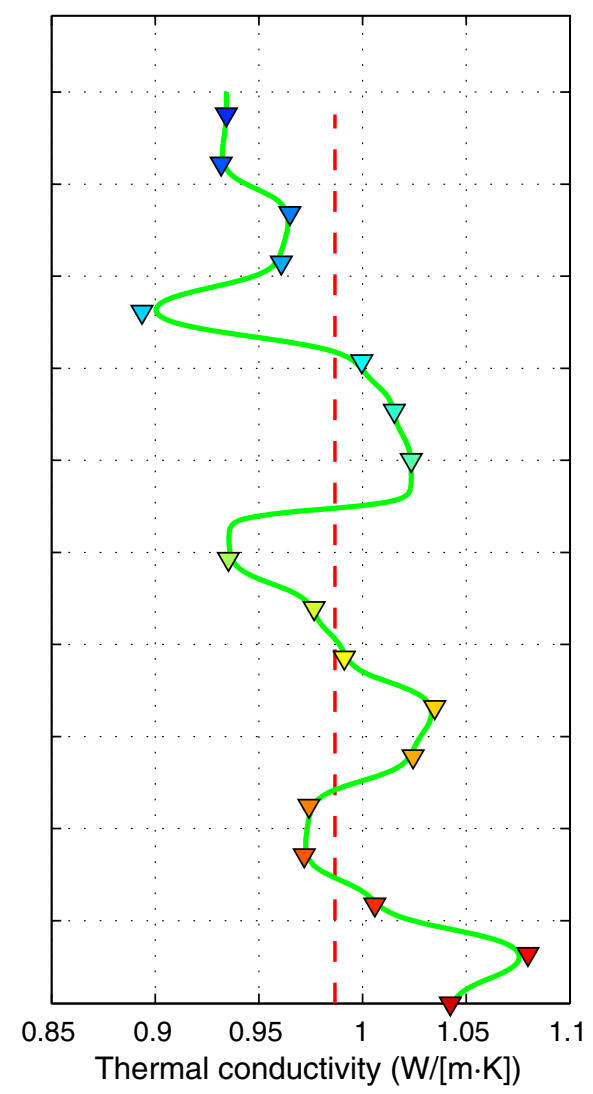

Mean therm. cond.: $0.99 \mathrm{~W} /(\mathrm{m} \cdot \mathrm{K})$ Measured thermal conductivity
C

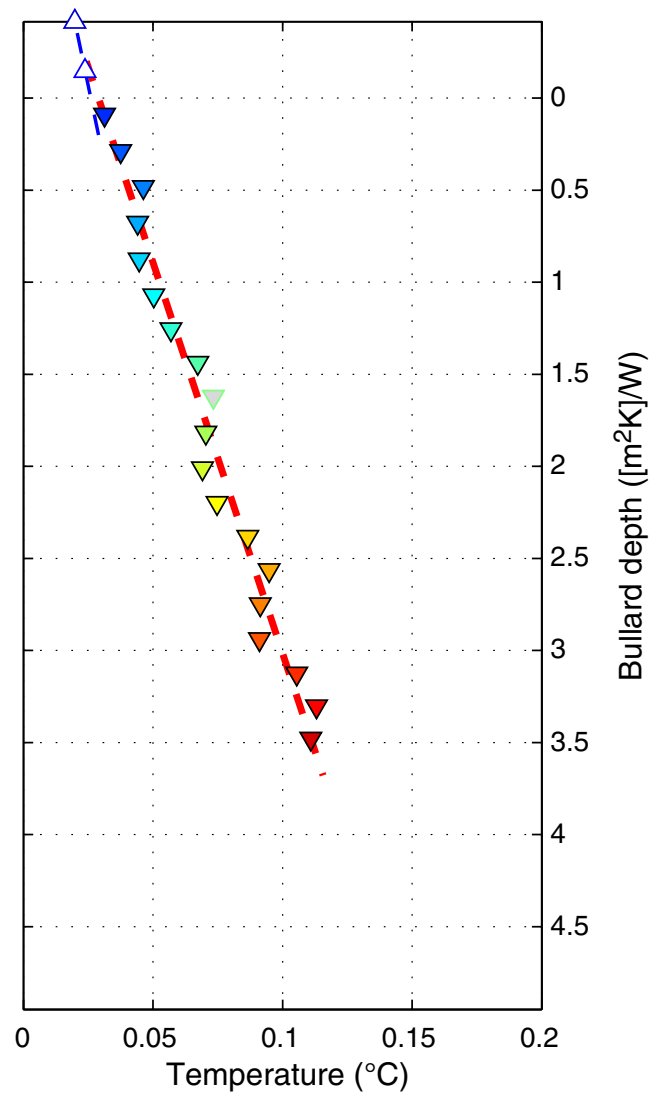

Heat-flux: $23.55 \mathrm{~mW} / \mathrm{m}^{2}$ $\mathrm{T}(0): 0.029^{\circ} \mathrm{C}$

$\mathrm{T}(0)$ (sediment: $14.91^{\circ} \mathrm{C} / \mathrm{km}$

$\mathrm{T}(0)$ (seawater): $0.026^{\circ} \mathrm{C}$ 
Figure F9. Map showing heat flow values from Langseth et al. (1992) (circles) and Cruise MSM 11/1 (triangles). Color coding is based on heat flow value. Stars = DSDP, ODP, and IODP sites.
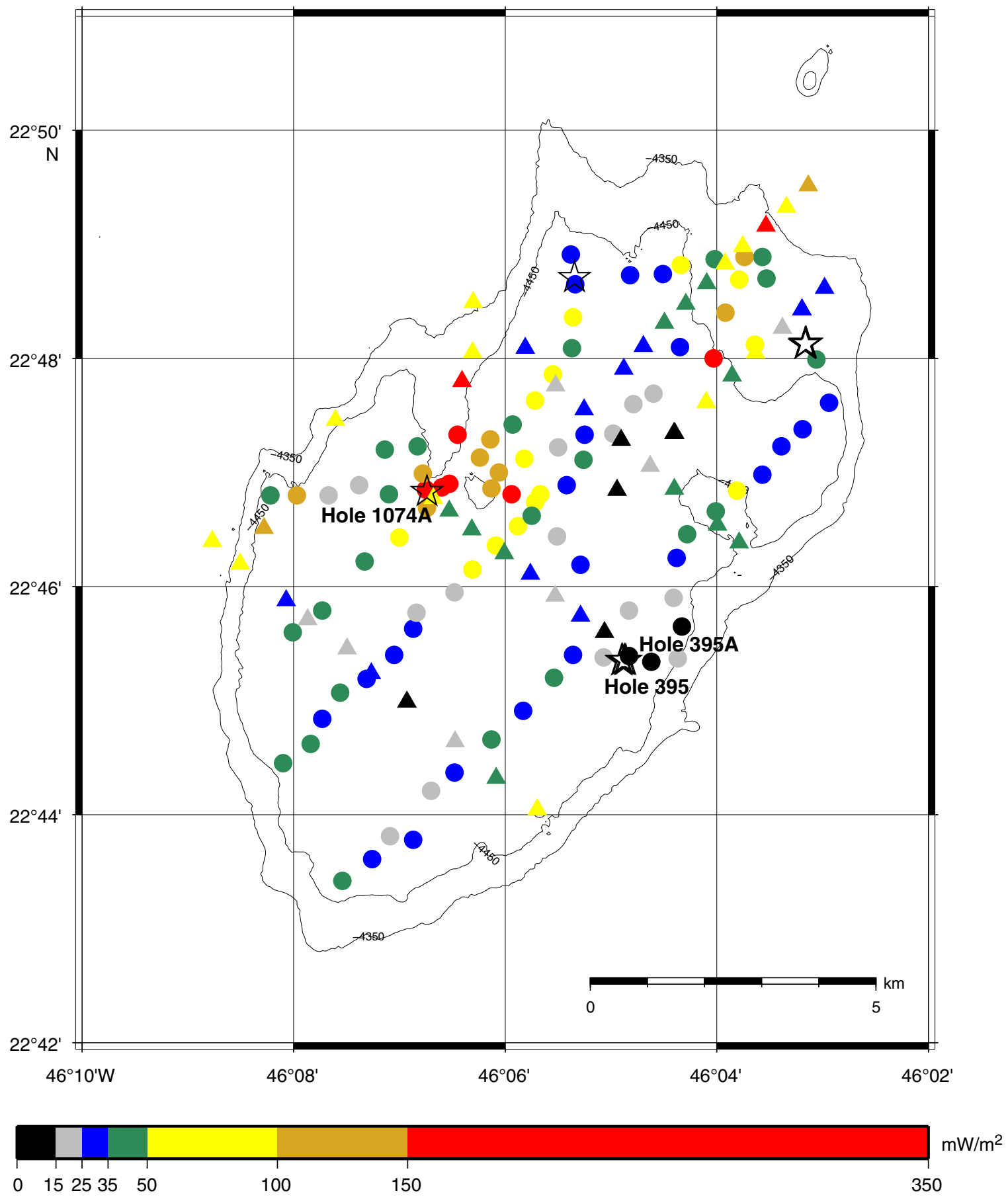
Figure F10. Comparison of thermal conductivity measurements. A. In situ data. B. Data measured onboard on split cores. C. Data from Langseth et al. (1992).

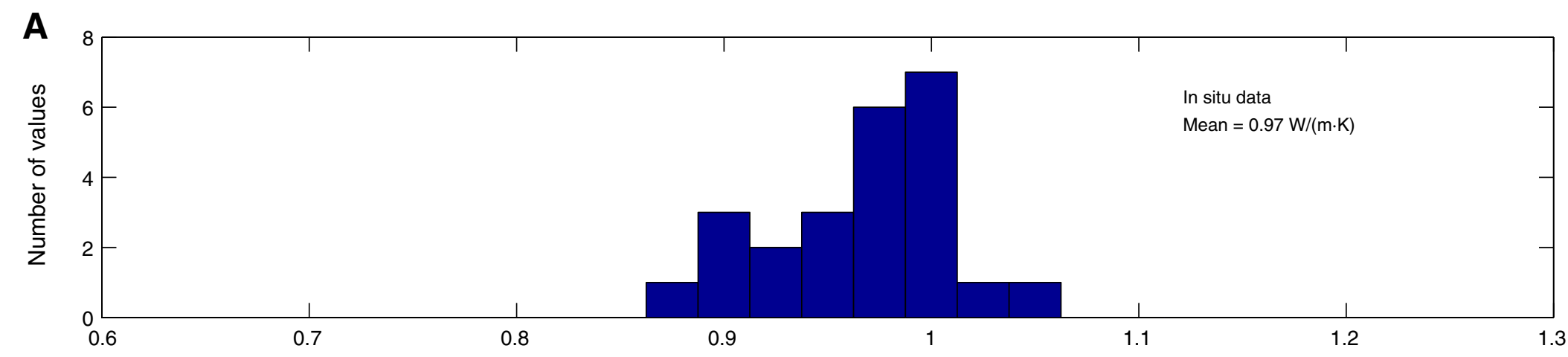

B

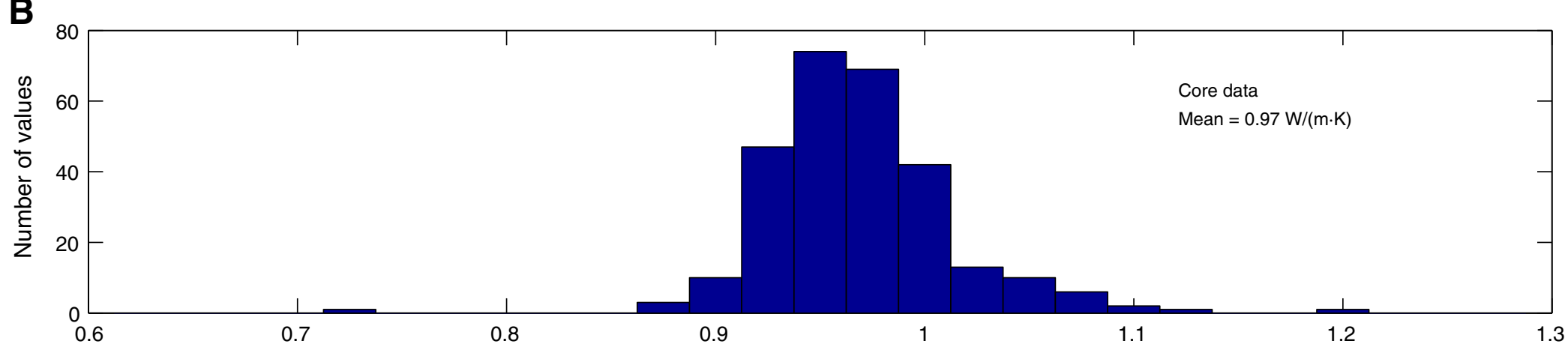

C

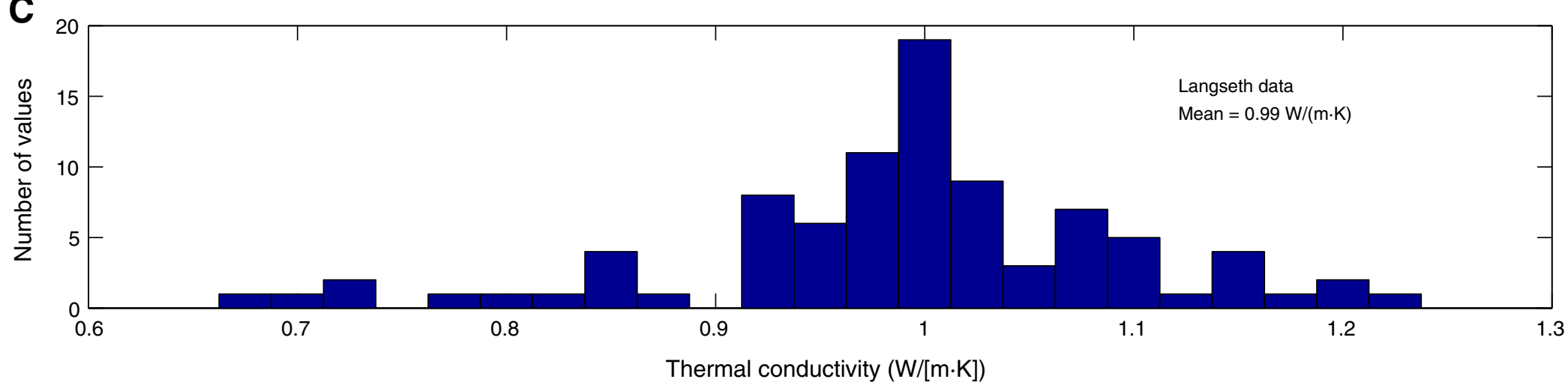


Table T1. Detailed summary of heat flow Profile HF-1.

\begin{tabular}{|c|c|c|c|c|c|c|c|c|c|c|}
\hline Penetration & $\begin{array}{l}\text { Depth } \\
(\mathrm{m})\end{array}$ & $\begin{array}{l}\text { Date } \\
(2009)\end{array}$ & $\begin{array}{l}\text { PenTime } \\
\text { (UTC) }\end{array}$ & Latitude & Longitude & $\begin{array}{l}\text { Seismic } \\
\text { profile } \\
\text { number }\end{array}$ & $\begin{array}{l}\text { Shotpoint } \\
\text { number }\end{array}$ & $\begin{array}{l}\text { Distance to } \\
\text { next shotpoint } \\
(\mathrm{km})\end{array}$ & $\begin{array}{l}\text { Thermal } \\
\text { conductivity } \\
(\mathrm{W} /[\mathrm{m} \cdot \mathrm{K}])\end{array}$ & $\begin{array}{c}\text { Heat } \\
\text { flow } \\
\left(\mathrm{mW} / \mathrm{m}^{2}\right)\end{array}$ \\
\hline \multicolumn{11}{|l|}{ Profile 1} \\
\hline H0901P01 & 4480 & $28 \mathrm{Feb}$ & $20: 18: 00$ & $22^{\circ} 47.926^{\prime} \mathrm{N}$ & $46^{\circ} 4.867^{\prime} \mathrm{W}$ & SCS_11 & 527 & 0.019 & 0.92 & 27.1 \\
\hline H0901P02 & 4478 & 28 Feb & $21: 31: 00$ & $22^{\circ} 48.159^{\prime} \mathrm{N}$ & $46^{\circ} 4.644^{\prime} \mathrm{W}$ & SCS_11 & 549 & 0.034 & - & 33.8 \\
\hline H0901P03 & 4479 & 28 Feb & $22: 24: 40$ & $22^{\circ} 48.358^{\prime} \mathrm{N}$ & $46^{\circ} 4.448^{\prime} \mathrm{W}$ & SCS_11 & 568 & 0.069 & 1.049 & 43.9 \\
\hline H0901P04 & 4468 & 28 Feb & $23: 26: 20$ & $22^{\circ} 48.508^{\prime} \mathrm{N}$ & $46^{\circ} 4.247^{\prime} \mathrm{W}$ & SCS_11 & 585 & 0.028 & - & 47.1 \\
\hline H0901P05 & 4411 & $1 \mathrm{Mar}$ & 00:19:10 & $22^{\circ} 48.717^{\prime} \mathrm{N}$ & $46^{\circ} 4.038^{\prime} \mathrm{W}$ & SCS_11 & 606 & 0.051 & 0.96 & 39.3 \\
\hline H0901P06 & 4406 & $1 \mathrm{Mar}$ & $01: 14: 30$ & $22^{\circ} 48.878^{\prime} \mathrm{N}$ & $46^{\circ} 3.868^{\prime} \mathrm{W}$ & SCS_11 & 622 & 0.064 & - & 52.4 \\
\hline H0901P07 & 4401 & $1 \mathrm{Mar}$ & $01: 56: 10$ & $22^{\circ} 49.047^{\prime} \mathrm{N}$ & $46^{\circ} 3.688^{\prime} \mathrm{W}$ & SCS_11 & 639 & 0.079 & 0.98 & 89.5 \\
\hline Н0901P08 & 4348 & $1 \mathrm{Mar}$ & $02: 52: 30$ & $22^{\circ} 49.207^{\prime} \mathrm{N}$ & $46^{\circ} 3.488^{\prime} \mathrm{W}$ & SCS_11 & 657 & 0.052 & - & 250.1 \\
\hline H0901P09 & 4259 & $1 \mathrm{Mar}$ & 03:36:00 & $22^{\circ} 49.387^{\prime} \mathrm{N}$ & $46^{\circ} 3.292^{\prime} \mathrm{W}$ & SCS_11 & 675 & 0.055 & 0.42 & 58.6 \\
\hline H0901P10 & 4184 & $1 \mathrm{Mar}$ & 04:33:00 & $22^{\circ} 49.575^{\prime} \mathrm{N}$ & $46^{\circ} 3.292^{\prime} \mathrm{W}$ & SCS_11 & 685 & 0.295 & - & 130 \\
\hline H0901P11 & 4108 & 1 Mar & $05: 18: 39$ & $22^{\circ} 49.747^{\prime} \mathrm{N}$ & $46^{\circ} 2.889^{\prime} \mathrm{W}$ & SCS_11 & 712 & 0.050 & NA & NA \\
\hline H0901P12 & 4014 & $1 \mathrm{Mar}$ & $06: 18: 35$ & $22^{\circ} 49.917^{\prime} \mathrm{N}$ & $46^{\circ} 2.707^{\prime} \mathrm{W}$ & SCS_11 & 730 & 0.053 & NA & NA \\
\hline
\end{tabular}

UTC $=$ Universal Time Coordinated. $-=$ no measurement taken, NA $=$ either probe did not penetrate or measurements could not be processed. See Figure F5 for location of heat flow measurement locations.

Table T2. Detailed summary of heat flow Profile HF-2.

\begin{tabular}{|c|c|c|c|c|c|c|c|c|c|c|}
\hline Penetration & $\begin{array}{l}\text { Depth } \\
\text { (m) }\end{array}$ & $\begin{array}{l}\text { Date } \\
\text { (2009) }\end{array}$ & $\begin{array}{l}\text { PenTime } \\
\text { (UTC) }\end{array}$ & Latitude & Longitude & $\begin{array}{l}\text { Seismic } \\
\text { profile } \\
\text { number }\end{array}$ & $\begin{array}{c}\text { Shotpoint } \\
\text { number }\end{array}$ & $\begin{array}{l}\text { Distance to } \\
\text { next shotpoint } \\
(\mathrm{km})\end{array}$ & $\begin{array}{l}\text { Thermal } \\
\text { conductivity } \\
(\mathrm{W} /[\mathrm{m} \cdot \mathrm{K}])\end{array}$ & $\begin{array}{c}\text { Heat } \\
\text { flow } \\
\left(\mathrm{mW} / \mathrm{m}^{2}\right)\end{array}$ \\
\hline \multicolumn{11}{|l|}{ Profile 2} \\
\hline H0902P01 & 4476 & 1 Mar & $22: 25: 50$ & $22^{\circ} 44.971^{\prime} \mathrm{N}$ & $46^{\circ} 4.311^{\prime} \mathrm{W}$ & SCS_13 & 752 & 0.044 & NA & NA \\
\hline H0902P02 & 4473 & $1 \mathrm{Mar}$ & $23: 29: 50$ & $22^{\circ} 45.162^{\prime} \mathrm{N}$ & $46^{\circ} 4.542^{\prime} \mathrm{W}$ & SCS_13 & 771 & 0.055 & NA & NA \\
\hline H0902P03 & 4482 & $2 \mathrm{Mar}$ & $00: 55: 40$ & $22^{\circ} 45.603^{\prime} \mathrm{N}$ & $46^{\circ} 5.080^{\prime} \mathrm{W}$ & SCS_13 & 817 & 0.098 & 0.96 & 5.3 \\
\hline H0902P04 & 4483 & $2 \mathrm{Mar}$ & $01: 48: 10$ & $22^{\circ} 45.746^{\prime} \mathrm{N}$ & $46^{\circ} 5.292^{\prime} \mathrm{W}$ & SCS_13 & 834 & 0.070 & - & 34.5 \\
\hline H0902P05 & 4484 & $2 \mathrm{Mar}$ & $02: 42: 10$ & $22^{\circ} 45.920^{\prime} \mathrm{N}$ & $46^{\circ} 5.528^{\prime} \mathrm{W}$ & SCS_13 & 855 & 0.061 & 0.90 & 20.8 \\
\hline H0902P06 & 4483 & $2 \mathrm{Mar}$ & 03:42:20 & $22^{\circ} 46.106^{\prime} \mathrm{N}$ & $46^{\circ} 5.764^{\prime} \mathrm{W}$ & SCS_13 & 876 & 0.070 & - & 34.6 \\
\hline H0902P07 & 4482 & $2 \mathrm{Mar}$ & $04: 32: 10$ & $22^{\circ} 46.292^{\prime} \mathrm{N}$ & $46^{\circ} 6.016^{\prime} \mathrm{W}$ & SCS_13 & 899 & 0.061 & 0.99 & 40.3 \\
\hline H0902P08 & 4479 & $2 \mathrm{Mar}$ & $05: 36: 30$ & $22^{\circ} 46.505^{\prime} \mathrm{N}$ & $46^{\circ} 6.320^{\prime} \mathrm{W}$ & SCS_13 & 925 & 0.009 & - & 43 \\
\hline H0902P09 & 4480 & $2 \mathrm{Mar}$ & $06: 25: 30$ & $22^{\circ} 46.668^{\prime} \mathrm{N}$ & $46^{\circ} 6.543^{\prime} \mathrm{W}$ & SCS_13 & 945 & 0.015 & 0.94 & 35.6 \\
\hline H0902P10 & 4475 & $2 \mathrm{Mar}$ & 07:17:30 & $22^{\circ} 46.776^{\prime} \mathrm{N}$ & $46^{\circ} 6.683^{\prime} \mathrm{W}$ & SCS_13 & 958 & 0.011 & - & 69.5 \\
\hline H0902P11 & 4483 & $2 \mathrm{Mar}$ & 08:04:39 & $22^{\circ} 46.931^{\prime} \mathrm{N}$ & $46^{\circ} 6.900^{\prime} \mathrm{W}$ & SCS_13 & 978 & 0.034 & NA & NA \\
\hline H0902P12 & 4480 & $2 \mathrm{Mar}$ & 08:58:35 & $22^{\circ} 47.061^{\prime} \mathrm{N}$ & $46^{\circ} 7.087^{\prime} \mathrm{W}$ & SCS_13 & 994 & 0.071 & NA & NA \\
\hline H0902P13 & 4477 & $2 \mathrm{Mar}$ & $09: 49: 35$ & $22^{\circ} 47.235^{\prime} \mathrm{N}$ & $46^{\circ} 7.319^{\prime} \mathrm{W}$ & SCS_13 & 1016 & 0.086 & NA & NA \\
\hline H0902P14 & 4408 & $2 \mathrm{Mar}$ & $10: 50: 40$ & $22^{\circ} 47.459^{\prime} \mathrm{N}$ & $46^{\circ} 7.612^{\prime} \mathrm{W}$ & SCS_13 & 1044 & 0.088 & 0.88 & 70 \\
\hline
\end{tabular}

UTC $=$ Universal Time Coordinated. $-=$ no measurement taken, NA $=$ either probe did not penetrate or measurements could not be processed. See Figure F5 for location of heat flow measurement locations. 
Table T3. Detailed summary of heat flow Profile HF-3.

\begin{tabular}{|c|c|c|c|c|c|c|c|c|c|c|}
\hline Penetration & $\begin{array}{l}\text { Depth } \\
(\mathrm{m})\end{array}$ & $\begin{array}{l}\text { Date } \\
\text { (2009) }\end{array}$ & $\begin{array}{l}\text { PenTime } \\
\text { (UTC) }\end{array}$ & Latitude & Longitude & $\begin{array}{l}\text { Seismic } \\
\text { profile } \\
\text { number }\end{array}$ & $\begin{array}{c}\text { Shotpoint } \\
\text { number }\end{array}$ & $\begin{array}{l}\text { Distance to } \\
\text { next shotpoint } \\
(\mathrm{km})\end{array}$ & $\begin{array}{l}\text { Thermal } \\
\text { conductivity } \\
(\mathrm{W} /[\mathrm{m} \cdot \mathrm{K}])\end{array}$ & $\begin{array}{c}\text { Heat } \\
\text { flow } \\
\left(\mathrm{mW} / \mathrm{m}^{2}\right)\end{array}$ \\
\hline \multicolumn{11}{|l|}{ Profile 3} \\
\hline H0903P01 & 4449 & $2 \mathrm{Mar}$ & $23: 50: 30$ & $22^{\circ} 46.274^{\prime} \mathrm{N}$ & $46^{\circ} 3.665^{\prime} \mathrm{W}$ & SCS_12 & 456 & 0.031 & NA & NA \\
\hline H0903P02 & 4437 & 3 Mar & $00: 41: 00$ & $22^{\circ} 46.385^{\prime} \mathrm{N}$ & $46^{\circ} 3.790^{\prime} \mathrm{W}$ & SCS_12 & 443 & 0.015 & - & 37.8 \\
\hline H0903Р03 & 4416 & $3 \mathrm{Mar}$ & $01: 22: 10$ & $22^{\circ} 46.840^{\prime} \mathrm{N}$ & $46^{\circ} 3.994^{\prime} \mathrm{W}$ & SCS_12 & 409 & 0.393 & 0.96 & 41.5 \\
\hline H0903P04 & 4476 & 3 Mar & $02: 37: 30$ & $22^{\circ} 46.856^{\prime} \mathrm{N}$ & $46^{\circ} 4.401^{\prime} \mathrm{W}$ & SCS_12 & 386 & 0.028 & - & 35.6 \\
\hline H0903P05 & 4481 & 3 Mar & $03: 22: 40$ & $22^{\circ} 47.056^{\prime} \mathrm{N}$ & $46^{\circ} 4.631^{\prime} \mathrm{W}$ & SCS_12 & 363 & 0.012 & 0.99 & 22.1 \\
\hline H0903P06 & 4482 & $3 \mathrm{Mar}$ & $04: 22: 40$ & $22^{\circ} 47.285^{\prime} \mathrm{N}$ & $46^{\circ} 4.905^{\prime} \mathrm{W}$ & SCS_12 & 338 & 0.018 & - & 5.7 \\
\hline Н0903Р07 & 4481 & $3 \mathrm{Mar}$ & $05: 22: 30$ & $22^{\circ} 47.552^{\prime} \mathrm{N}$ & $46^{\circ} 5.255^{\prime} \mathrm{W}$ & SCS_12 & 305 & 0.017 & 1.00 & 26.3 \\
\hline H0903Р08 & 4476 & 3 Mar & $06: 27: 20$ & $22^{\circ} 47.761^{\prime} \mathrm{N}$ & $46^{\circ} 5.524^{\prime} \mathrm{W}$ & SCS_12 & 281 & 0.024 & - & 24.3 \\
\hline H0903P09 & 4469 & 3 Mar & 07:45:30 & $22^{\circ} 48.091^{\prime} \mathrm{N}$ & $46^{\circ} 5.811^{\prime} \mathrm{W}$ & SCS_12 & 250 & 0.132 & - & 31 \\
\hline H0903P10 & 4420 & 3 Mar & 09:08:30 & $22^{\circ} 48.492^{\prime} \mathrm{N}$ & $46^{\circ} 6.383^{\prime} \mathrm{W}$ & SCS_12 & 203 & 0.065 & 0.98 & 54.7 \\
\hline H0903P11 & 4392 & $3 \mathrm{Mar}$ & 10:33:39 & $22^{\circ} 48.053^{\prime} \mathrm{N}$ & $46^{\circ} 6.309^{\prime} \mathrm{W}$ & SCS_12 & 1224 & 0.270 & - & 77.6 \\
\hline H0903P12 & 4381 & $3 \mathrm{Mar}$ & $11: 21: 35$ & $22^{\circ} 47.800^{\prime} \mathrm{N}$ & $46^{\circ} 6.409^{\prime} \mathrm{W}$ & SCS_12 & 1241 & 0.055 & - & 327 \\
\hline H0903P13 & 4371 & 3 Mar & $12: 07: 35$ & $22^{\circ} 47.477^{\prime} \mathrm{N}$ & $46^{\circ} 6.443^{\prime} \mathrm{W}$ & SCS_12 & 1258 & 0.337 & NA & NA \\
\hline
\end{tabular}

UTC = Universal Time Coordinated. $-=$ no measurement taken, NA = either probe did not penetrate or measurements could not be processed. See Figure F5 for location of heat flow measurement locations.

Table T4. Detailed summary of heat flow Profile HF-4.

\begin{tabular}{|c|c|c|c|c|c|c|c|c|c|c|}
\hline Penetration & $\begin{array}{l}\text { Depth } \\
(\mathrm{m})\end{array}$ & $\begin{array}{c}\text { Date } \\
(2009)\end{array}$ & $\begin{array}{l}\text { PenTime } \\
\text { (UTC) }\end{array}$ & Latitude & Longitude & $\begin{array}{l}\text { Seismic } \\
\text { profile } \\
\text { number }\end{array}$ & $\begin{array}{l}\text { Shotpoint } \\
\text { number }\end{array}$ & $\begin{array}{l}\text { Distance to } \\
\text { next shotpoint } \\
(\mathrm{km})\end{array}$ & $\begin{array}{l}\text { Thermal } \\
\text { conductivity } \\
(\mathrm{W} /[\mathrm{m} \cdot \mathrm{K}])\end{array}$ & $\begin{array}{c}\text { Heat } \\
\text { flow } \\
\left(\mathrm{mW} / \mathrm{m}^{2}\right)\end{array}$ \\
\hline \multicolumn{11}{|l|}{ Profile 4} \\
\hline H0904P01 & 4478 & 3 Mar & $21: 03: 20$ & $22^{\circ} 44.045^{\prime} \mathrm{N}$ & $46^{\circ} 5.697^{\prime} \mathrm{W}$ & SCS_14 & 1736 & 0.028 & 0.99 & 61.9 \\
\hline H0904P02 & 4482 & $3 \mathrm{Mar}$ & $22: 23: 30$ & $22^{\circ} 44.321^{\prime} \mathrm{N}$ & $46^{\circ} 6.085^{\prime} \mathrm{W}$ & SCS_14 & 1703 & 0.055 & - & 48.8 \\
\hline H0904P03 & 4489 & $3 \mathrm{Mar}$ & $23: 34: 40$ & $22^{\circ} 44.642^{\prime} \mathrm{N}$ & $46^{\circ} 6.474^{\prime} \mathrm{W}$ & SCS_14 & 1669 & 0.031 & 0.99 & 16.3 \\
\hline H0904P04 & 4485 & $4 \mathrm{Mar}$ & $00: 52: 30$ & $22^{\circ} 44.989^{\prime} \mathrm{N}$ & $46^{\circ} 6.930^{\prime} \mathrm{W}$ & SCS_14 & 1629 & 0.032 & - & 14 \\
\hline H0904P05 & 4483 & $4 \mathrm{Mar}$ & 01:45:00 & $22^{\circ} 45.238^{\prime} \mathrm{N}$ & $46^{\circ} 7.266^{\prime} \mathrm{W}$ & SCS_14 & 1601 & 0.016 & 1.00 & 32.4 \\
\hline H0904P06 & 4489 & $4 \mathrm{Mar}$ & 02:46:00 & $22^{\circ} 45.456^{\prime} \mathrm{N}$ & $46^{\circ} 7.495^{\prime} \mathrm{W}$ & SCS_14 & 1579 & 0.049 & - & 19.1 \\
\hline H0904P07 & 4489 & $4 \mathrm{Mar}$ & $03: 44: 40$ & $22^{\circ} 45.712^{\prime} \mathrm{N}$ & $46^{\circ} 7.868^{\prime} \mathrm{W}$ & SCS_14 & 1548 & 0.008 & 0.99 & 24.3 \\
\hline H0904P08 & 4484 & $4 \mathrm{Mar}$ & $04: 32: 30$ & $22^{\circ} 45.878^{\prime} \mathrm{N}$ & $46^{\circ} 8.071^{\prime} \mathrm{W}$ & SCS_14 & 1530 & 0.028 & - & 25.4 \\
\hline H0904P09 & 4363 & $4 \mathrm{Mar}$ & $05: 37: 30$ & $22^{\circ} 46.200^{\prime} \mathrm{N}$ & $46^{\circ} 8.506^{\prime} \mathrm{W}$ & SCS_14 & 1493 & 0.018 & 0.98 & 87.5 \\
\hline H0904P10 & 4206 & $4 \mathrm{Mar}$ & $06: 39: 20$ & $22^{\circ} 46.399^{\prime} \mathrm{N}$ & $46^{\circ} 8.769^{\prime} \mathrm{W}$ & SCS_14 & 1471 & 0.020 & - & 61.3 \\
\hline H0904P11 & 4476 & $4 \mathrm{Mar}$ & $07: 58: 39$ & $22^{\circ} 46.511^{\prime} \mathrm{N}$ & $46^{\circ} 8.281^{\prime} \mathrm{W}$ & SCS_14 & 1398 & 0.565 & - & 118.7 \\
\hline
\end{tabular}

UTC = Universal Time Coordinated. - no measurement taken. See Figure F5 for location of heat flow measurement locations. 
Table T5. Detailed summary of heat flow Profile HF-5.

\begin{tabular}{|c|c|c|c|c|c|c|c|c|c|c|}
\hline Penetration & $\begin{array}{l}\text { Depth } \\
(\mathrm{m})\end{array}$ & $\begin{array}{l}\text { Date } \\
(2009)\end{array}$ & $\begin{array}{l}\text { PenTime } \\
\text { (UTC) }\end{array}$ & Latitude & Longitude & $\begin{array}{l}\text { Seismic } \\
\text { profile } \\
\text { number }\end{array}$ & $\begin{array}{c}\text { Shotpoint } \\
\text { number }\end{array}$ & $\begin{array}{l}\text { Distance to } \\
\text { next shotpoint } \\
(\mathrm{km})\end{array}$ & $\begin{array}{l}\text { Thermal } \\
\text { conductivity } \\
(\mathrm{W} /[\mathrm{m} \cdot \mathrm{K}])\end{array}$ & $\begin{array}{c}\text { Heat } \\
\text { flow } \\
\left(\mathrm{mW} / \mathrm{m}^{2}\right)\end{array}$ \\
\hline \multicolumn{11}{|l|}{ Profile 5} \\
\hline Н0905Р01 & 4481 & $4 \mathrm{Mar}$ & $22: 14: 00$ & $22^{\circ} 46.846^{\prime} \mathrm{N}$ & $46^{\circ} 4.944^{\prime} \mathrm{W}$ & SCS_10 & 7672 & 0.047 & 0.90 & 15.5 \\
\hline H0905P02 & 4481 & $4 \mathrm{Mar}$ & $22: 39: 40$ & $22^{\circ} 46.846^{\prime} \mathrm{N}$ & $46^{\circ} 4.944^{\prime} \mathrm{W}$ & SCS_10 & 7672 & 0.047 & 0.91 & 14.8 \\
\hline Н0905Р03 & 4480 & $5 \mathrm{Mar}$ & $00: 20: 30$ & $22^{\circ} 47.344^{\prime} \mathrm{N}$ & $46^{\circ} 4.405^{\prime} \mathrm{W}$ & SCS_10 & 7621 & 0.019 & - & 13.2 \\
\hline H0905P04 & 4481 & $5 \mathrm{Mar}$ & $00: 36: 20$ & $22^{\circ} 47.344^{\prime} \mathrm{N}$ & $46^{\circ} 4.398^{\prime} \mathrm{W}$ & SCS_10 & 7620 & 0.028 & - & 13.3 \\
\hline H0905P05 & 4484 & $5 \mathrm{Mar}$ & $01: 39: 20$ & $22^{\circ} 47.617^{\prime} \mathrm{N}$ & $46^{\circ} 4.101^{\prime} \mathrm{W}$ & SCS_10 & 7592 & 0.018 & 0.97 & 53.8 \\
\hline H0905P06 & 4473 & $5 \mathrm{Mar}$ & $02: 44: 40$ & $22^{\circ} 47.849^{\prime} \mathrm{N}$ & $46^{\circ} 3.856^{\prime} \mathrm{W}$ & SCS_10 & 7568 & 0.004 & - & 44.7 \\
\hline Н0905Р07 & 4401 & $5 \mathrm{Mar}$ & 03:40:00 & $22^{\circ} 48.049^{\prime} \mathrm{N}$ & $46^{\circ} 3.634^{\prime} \mathrm{W}$ & SCS_10 & 7547 & 0.004 & 0.99 & 90.3 \\
\hline Н0905Р08 & 4411 & $5 \mathrm{Mar}$ & $04: 42: 40$ & $22^{\circ} 48.266^{\prime} \mathrm{N}$ & $46^{\circ} 3.381^{\prime} \mathrm{W}$ & SCS_10 & 7523 & 0.009 & - & 23.6 \\
\hline H0905P09 & 4410 & $5 \mathrm{Mar}$ & $05: 29: 10$ & $22^{\circ} 48.428^{\prime} \mathrm{N}$ & $46^{\circ} 3.196^{\prime} \mathrm{W}$ & SCS_10 & 7505 & 0.023 & 1.00 & 32.7 \\
\hline H0905P10 & 4411 & $5 \mathrm{Mar}$ & $05: 52: 00$ & $22^{\circ} 48.428^{\prime} \mathrm{N}$ & $46^{\circ} 3.195^{\prime} \mathrm{W}$ & SCS_10 & 7505 & 0.024 & 1.01 & 33 \\
\hline H0905P11 & 4407 & $5 \mathrm{Mar}$ & $06: 42: 10$ & $22^{\circ} 48.616^{\prime} \mathrm{N}$ & $46^{\circ} 2.982^{\prime} \mathrm{W}$ & SCS_10 & 7483 & 0.028 & - & 30.2 \\
\hline
\end{tabular}

UTC $=$ Universal Time Coordinated. $-=$ no measurement taken. See Figure F5 for location of heat flow measurement locations.

Table T6. Sediment coring locations and recovered core length.

\begin{tabular}{clllcccc}
\hline \multicolumn{1}{c}{ Site } & Type & Latitude & Longitude & $\begin{array}{c}\text { Water } \\
\text { depth } \\
(\mathrm{m})\end{array}$ & $\begin{array}{c}\text { Core } \\
\text { length } \\
(\mathrm{cm})\end{array}$ & $\begin{array}{c}\text { Date } \\
(2009)\end{array}$ & $\begin{array}{c}\text { Local } \\
\text { time } \\
(\mathrm{h})\end{array}$ \\
\hline GeoB 13501 & GC $(12 \mathrm{~m})$ & $22^{\circ} 46.62^{\prime} \mathrm{N}$ & $46^{\circ} 6.42^{\prime} \mathrm{W}$ & 4480 & 844 & $21 \mathrm{Feb}$ & 1756 \\
GeoB 13502 & GC $(12 \mathrm{~m})$ & $22^{\circ} 49.41^{\prime} \mathrm{N}$ & $46^{\circ} 3.23^{\prime} \mathrm{W}$ & 4250 & 847 & $28 \mathrm{Feb}$ & 1700 \\
GeoB 13503 & GC $(12 \mathrm{~m})$ & $22^{\circ} 49.2^{\prime} \mathrm{N}$ & $46^{\circ} 3.5^{\prime} \mathrm{W}$ & 4365 & 689 & $01 \mathrm{Mar}$ & 0929 \\
GeoB 13504 & GC $(6 \mathrm{~m})$ & $22^{\circ} 49.89^{\prime} \mathrm{N}$ & $46^{\circ} 2.78^{\prime} \mathrm{W}$ & 4096 & 72 & $02 \mathrm{Mar}$ & 1229 \\
GeoB 13505 & GC $(12 \mathrm{~m})$ & $22^{\circ} 47.55^{\prime} \mathrm{N}$ & $46^{\circ} 7.4^{\prime} \mathrm{W}$ & 4402 & 76 & $02 \mathrm{Mar}$ & 1409 \\
GeoB 13506 & GC $(6 \mathrm{~m})$ & $22^{\circ} 48.36^{\prime} \mathrm{N}$ & $46^{\circ} 7.51^{\prime} \mathrm{W}$ & 4143 & 574 & $02 \mathrm{Mar}$ & 1709 \\
GeoB 13507 & GC $(12 \mathrm{~m})$ & $22^{\circ} 48.04^{\prime} \mathrm{N}$ & $46^{\circ} 6.3^{\prime} \mathrm{W}$ & 4395 & 865 & $03 \mathrm{Mar}$ & 1446 \\
GeoB 13508 & GC $(6 \mathrm{~m})$ & $22^{\circ} 46.89^{\prime} \mathrm{N}$ & $46^{\circ} 6.59^{\prime} \mathrm{W}$ & 4475 & 344 & $04 \mathrm{Mar}$ & 1043 \\
GeoB 13509 & GC $(3 \mathrm{~m})$ & $22^{\circ} 47.47^{\prime} \mathrm{N}$ & $46^{\circ} 6.45^{\prime} \mathrm{W}$ & 4438 & 267 & $04 \mathrm{Mar}$ & 1419 \\
GeoB 13510 & GC $(6 \mathrm{~m})$ & $22^{\circ} 47.35^{\prime} \mathrm{N}$ & $46^{\circ} 6.44^{\prime} \mathrm{W}$ & 4448 & 515 & $04 \mathrm{Mar}$ & 1646 \\
GeoB 13511 & GC $(6 \mathrm{~m})$ & $22^{\circ} 47.12^{\prime} \mathrm{N}$ & $46^{\circ} 6.49^{\prime} \mathrm{W}$ & 4445 & 468 & $04 \mathrm{Mar}$ & 1918 \\
GeoB 13512 & GC $(6 \mathrm{~m})$ & $22^{\circ} 49.33^{\prime} \mathrm{N}$ & $46^{\circ} 6.45^{\prime} \mathrm{W}$ & 4200 & 516 & $05 \mathrm{Mar}$ & 1002 \\
GeoB 13513 & GC $(6 \mathrm{~m})$ & $22^{\circ} 49^{\prime} \mathrm{N}$ & $46^{\circ} 2.64^{\prime} \mathrm{W}$ & 4262 & 504 & $05 \mathrm{Mar}$ & 1300 \\
GeoB 13514 & GC $(6 \mathrm{~m})$ & $22^{\circ} 49.15^{\prime} \mathrm{N}$ & $46^{\circ} 2.39^{\prime} \mathrm{W}$ & 4040 & 237 & $05 \mathrm{Mar}$ & 1522 \\
GeoB 13501 & MUC & $22^{\circ} 46.62^{\prime} \mathrm{N}$ & $46^{\circ} 6.42^{\prime} \mathrm{W}$ & 4480 & No recovery & $02 \mathrm{Mar}$ & 2021 \\
\hline
\end{tabular}

GC $=$ gravity core, MUC $=$ multicorer. Local time $=$ UTC. See Figure F5 for location of sediment cores. 


\section{Appendix}

Navigation track charts and Parasound and seismic records for Profiles 1-14 are shown in Figures AF1, AF2, AF3, AF4, AF5, AF6, AF7, AF8, AF9, AF10, AF11, AF12, AF13, AF14, AF15, AF16, AF17, AF18, AF19, AF20, AF21, AF22, AF23, AF24, AF25, AF26, AF27, AF28, AF29, AF30, AF31, AF32, AF33, AF34, AF35, AF36, AF37, AF38, AF39, AF40, AF41, and AF42. 
Figure AF1. Map showing shotpoint navigation for seismic and Parasound Profile 1. Stars = positions of DSDP, ODP, and IODP boreholes.

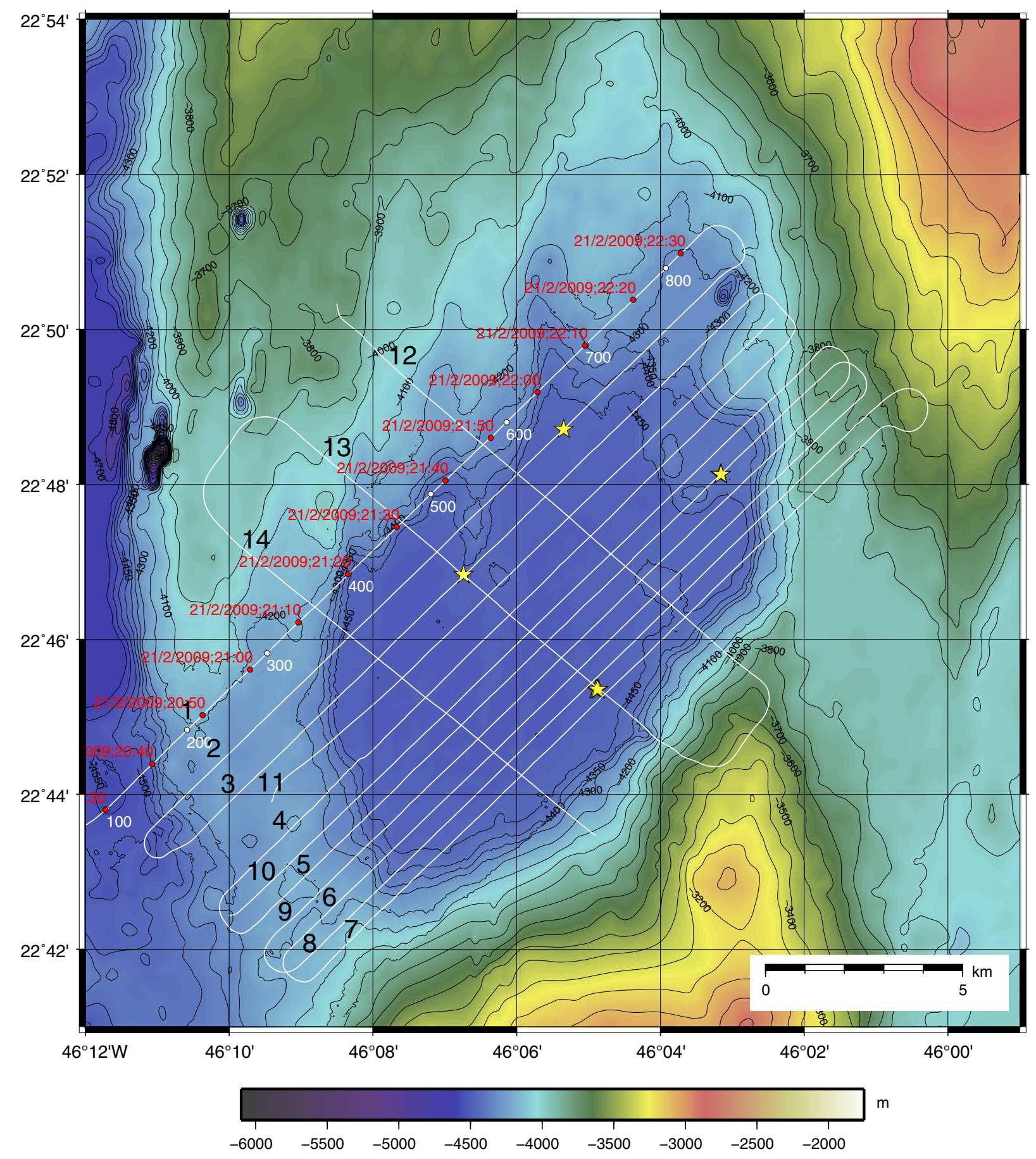


Figure AF2. Parasound record of Profile 1.

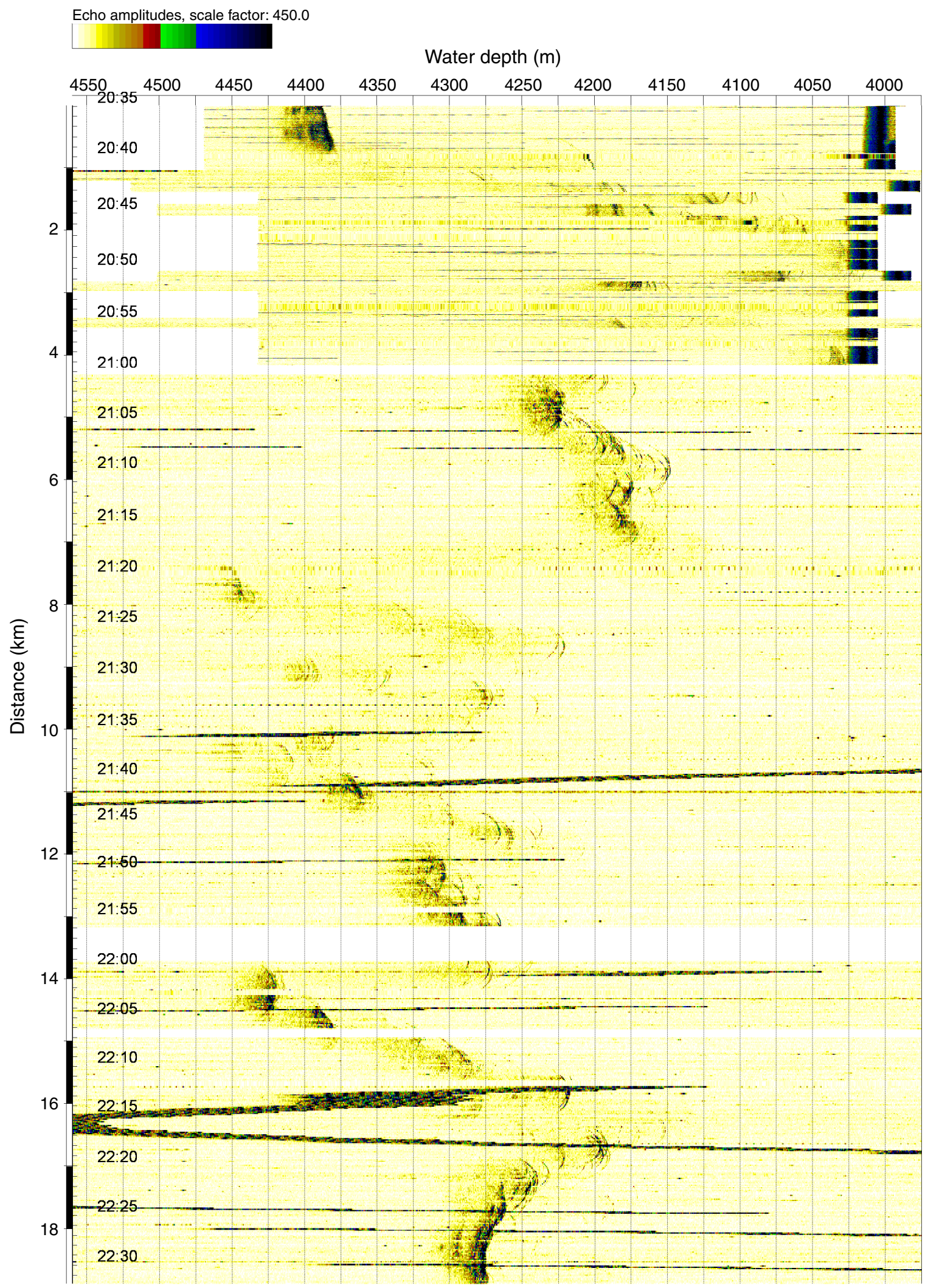




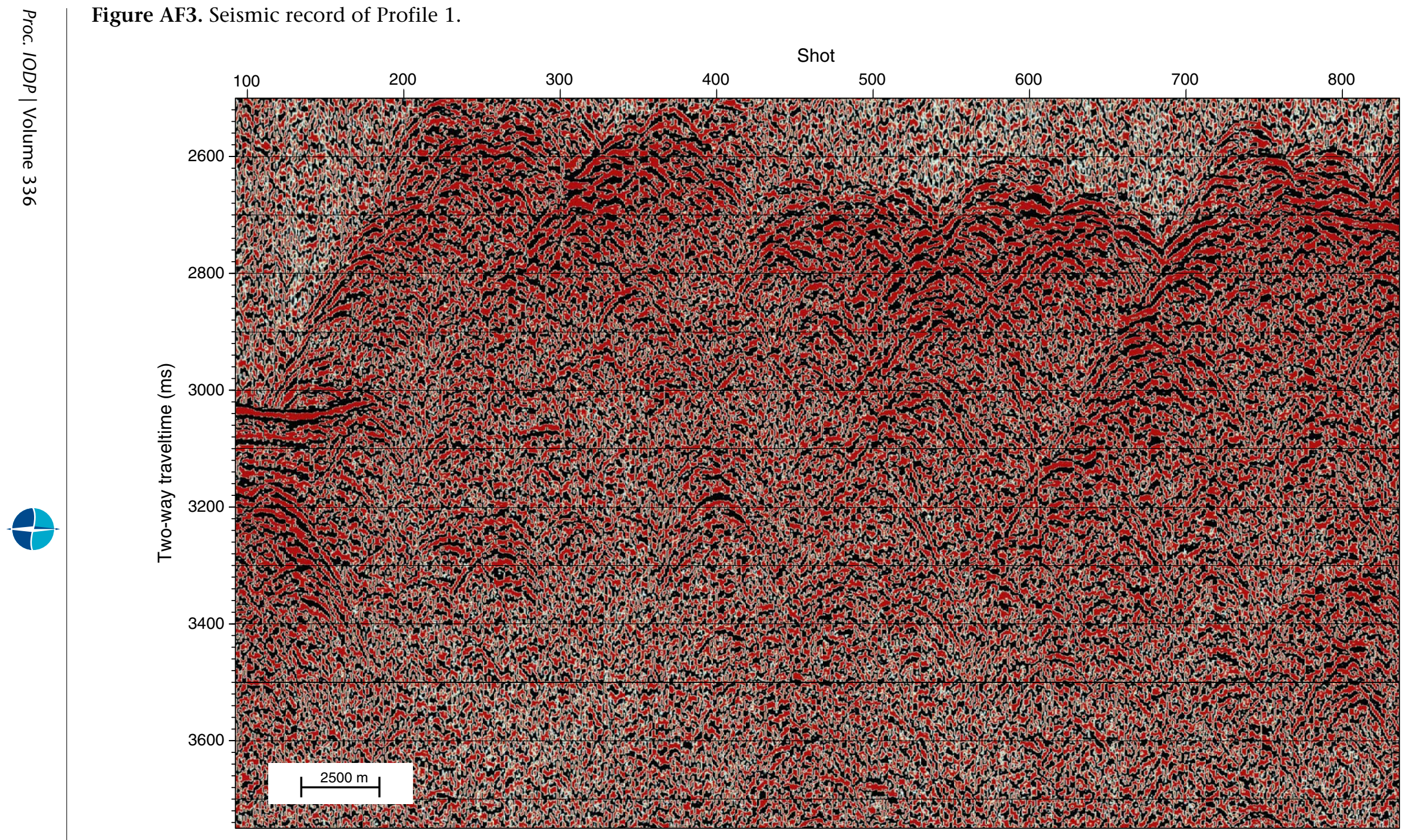


Figure AF4. Map showing shotpoint navigation for seismic and Parasound Profile 2. Stars = positions of DSDP, ODP, and IODP boreholes.

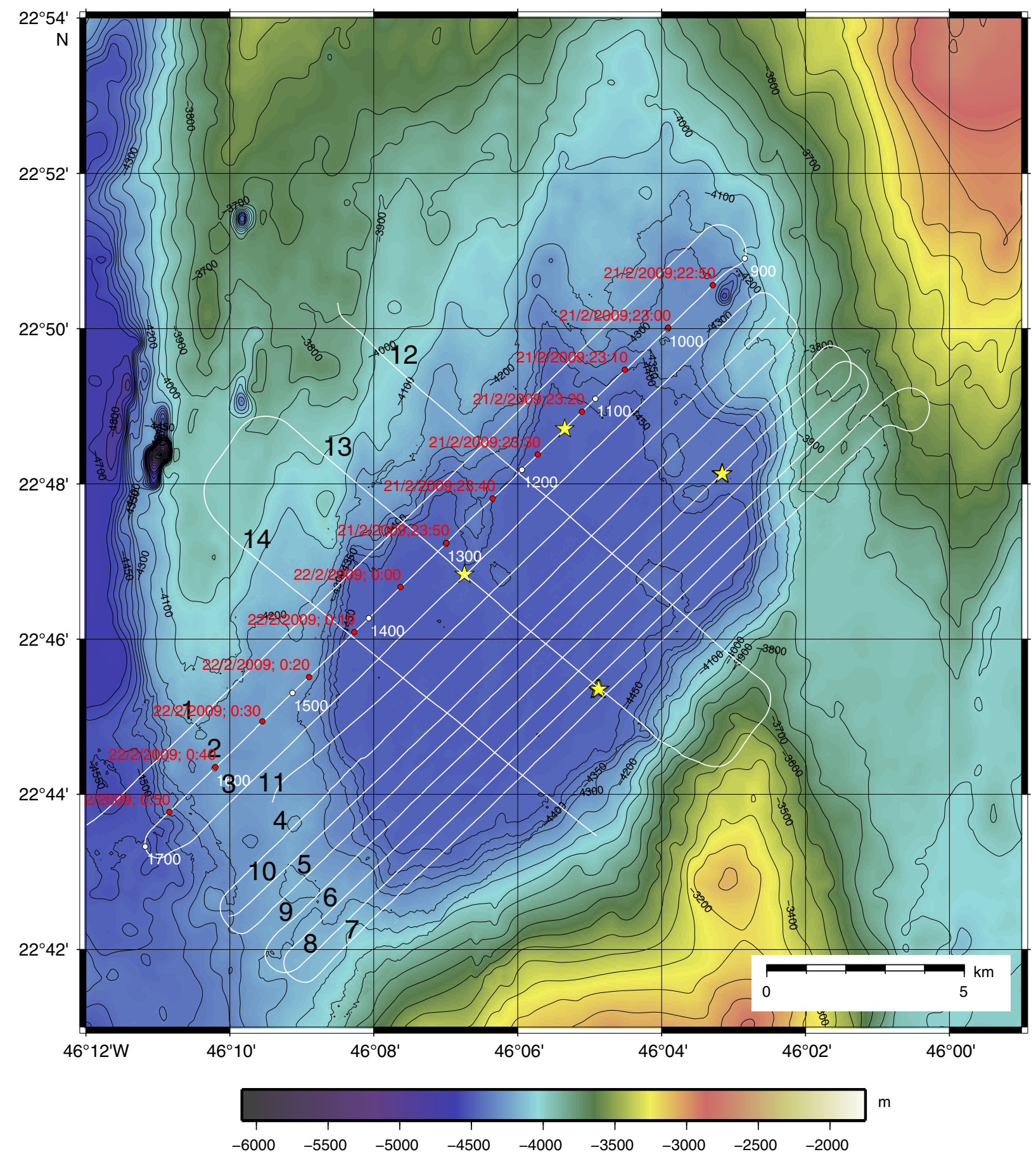


Figure AF5. Parasound record of Profile 2.

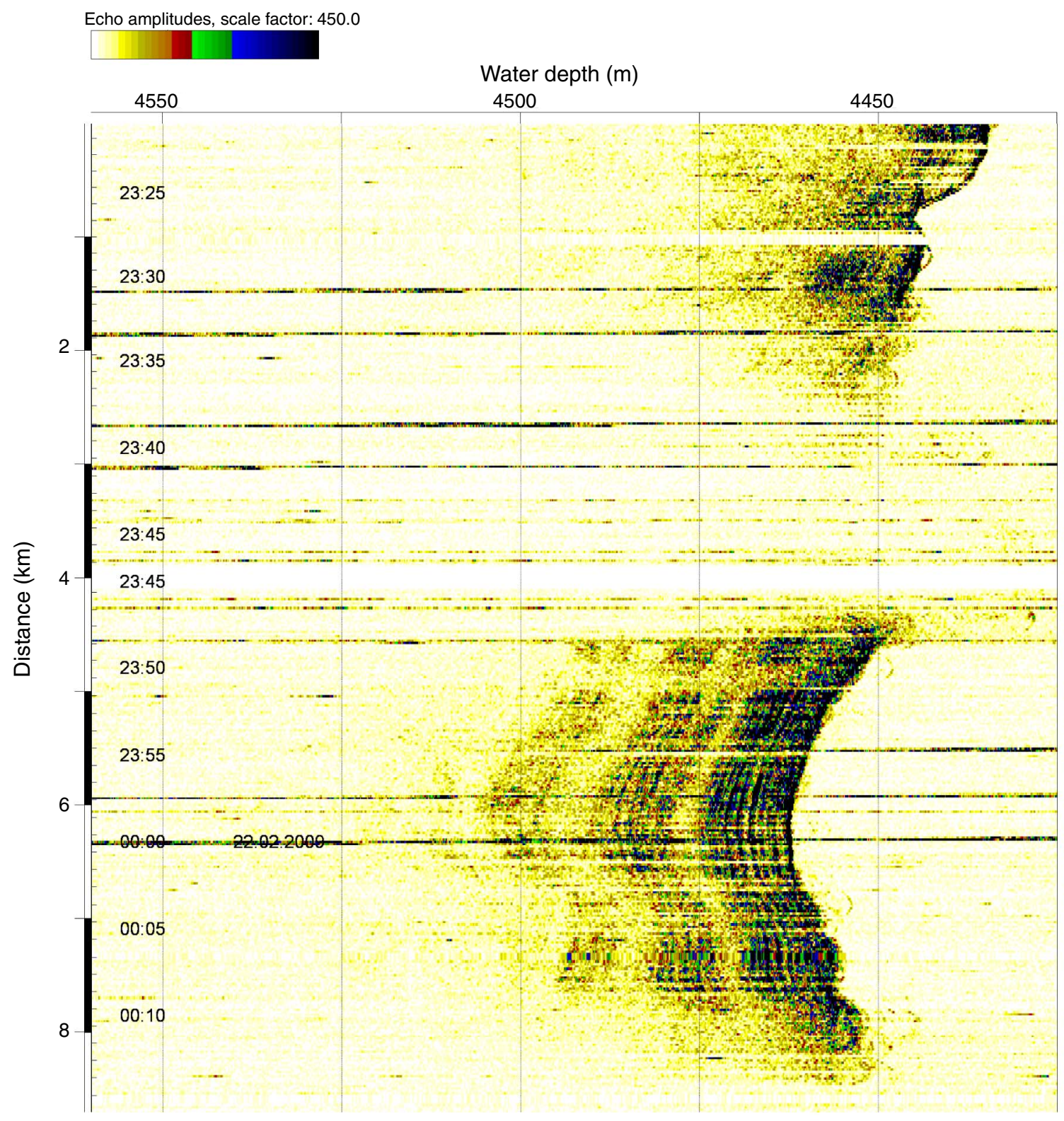


Figure AF6. Seismic record of Profile 2.

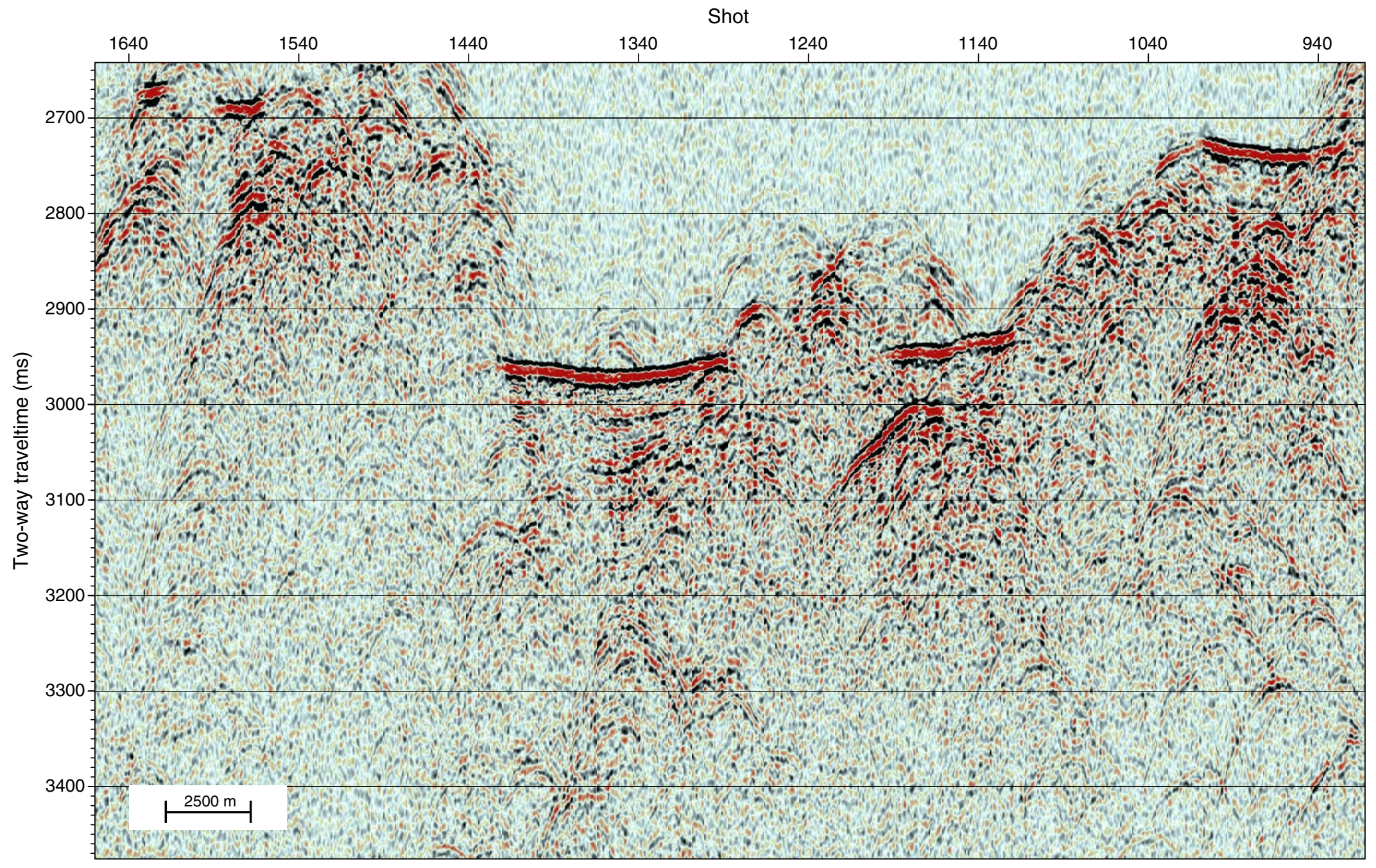


Figure AF7. Map showing shotpoint navigation for seismic and Parasound Profile 3. Stars = positions of DSDP, ODP, and IODP boreholes.

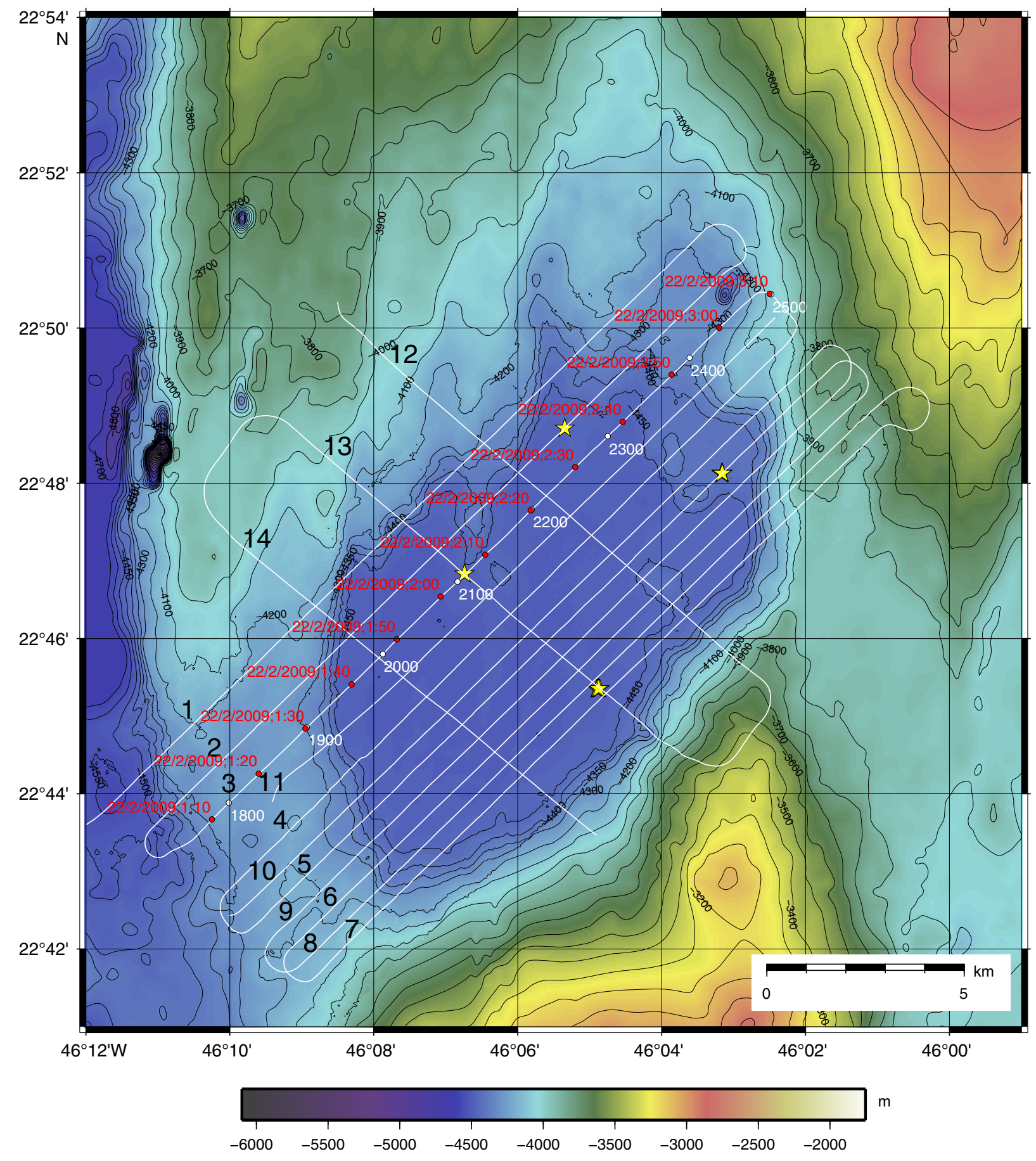


Figure AF8. Parasound record of Profile 3.

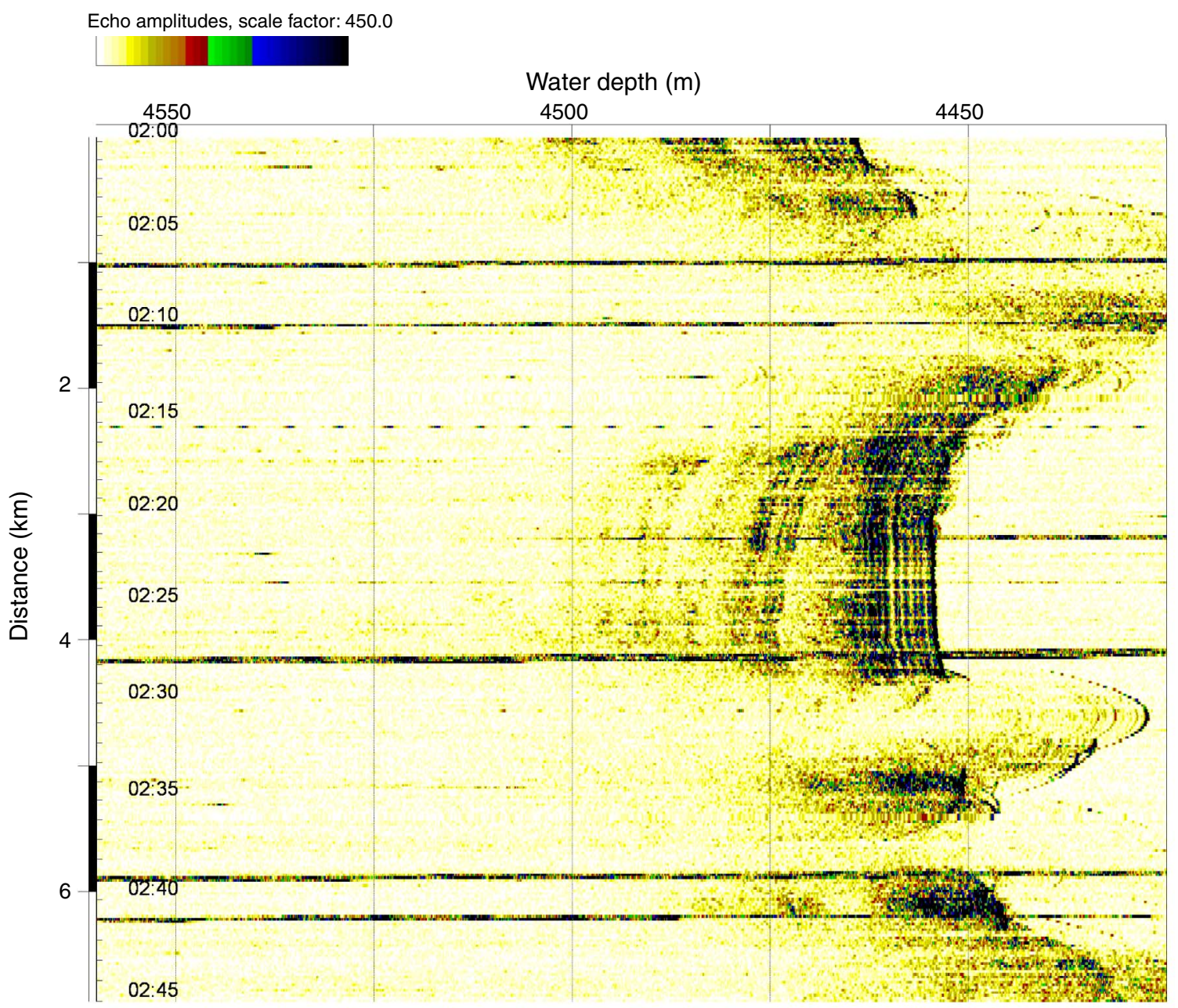


Figure AF9. Seismic record of Profile 3.

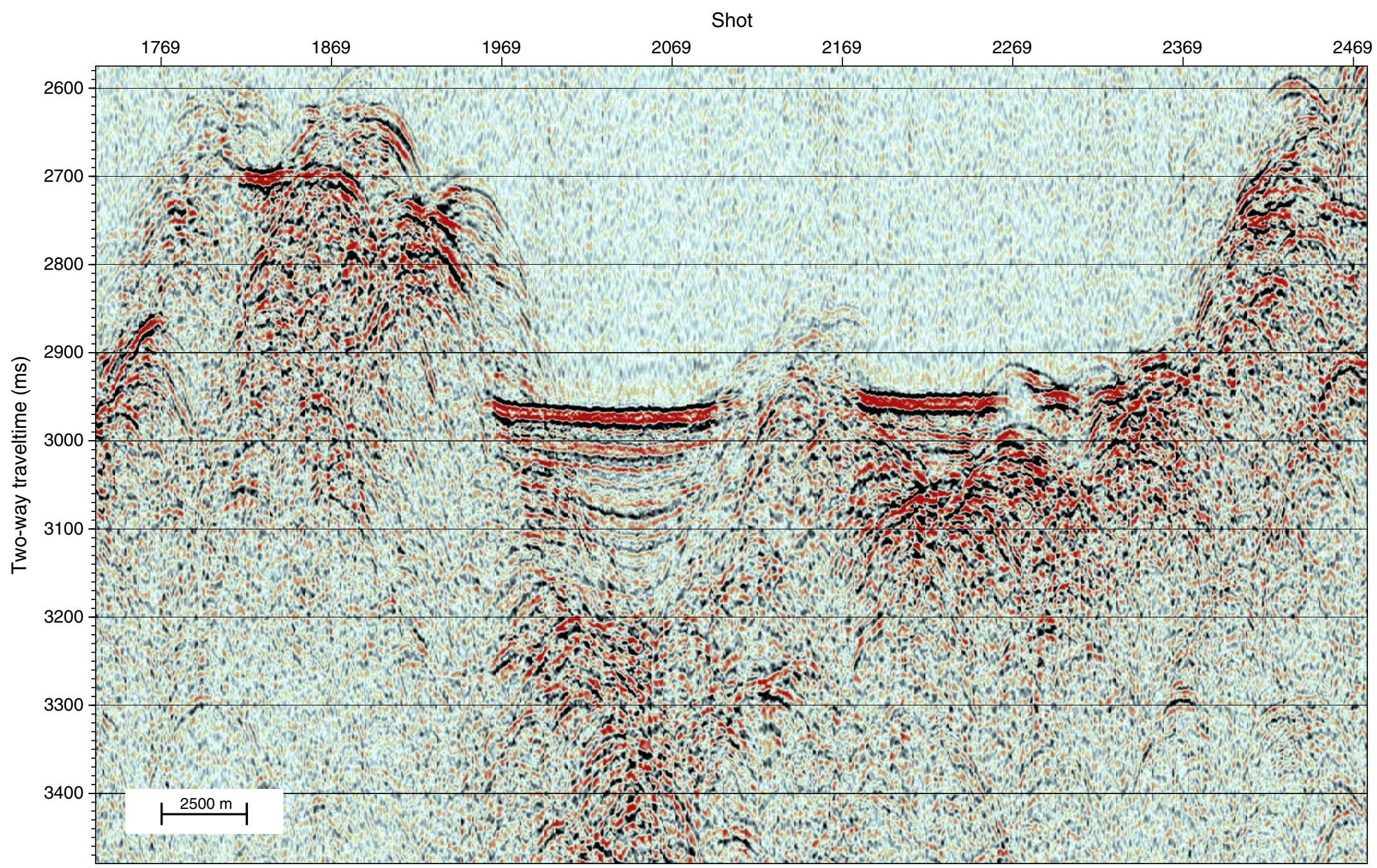


Figure AF10. Map showing shotpoint navigation for seismic and Parasound Profile 4. Stars = positions of DSDP, ODP, and IODP boreholes.

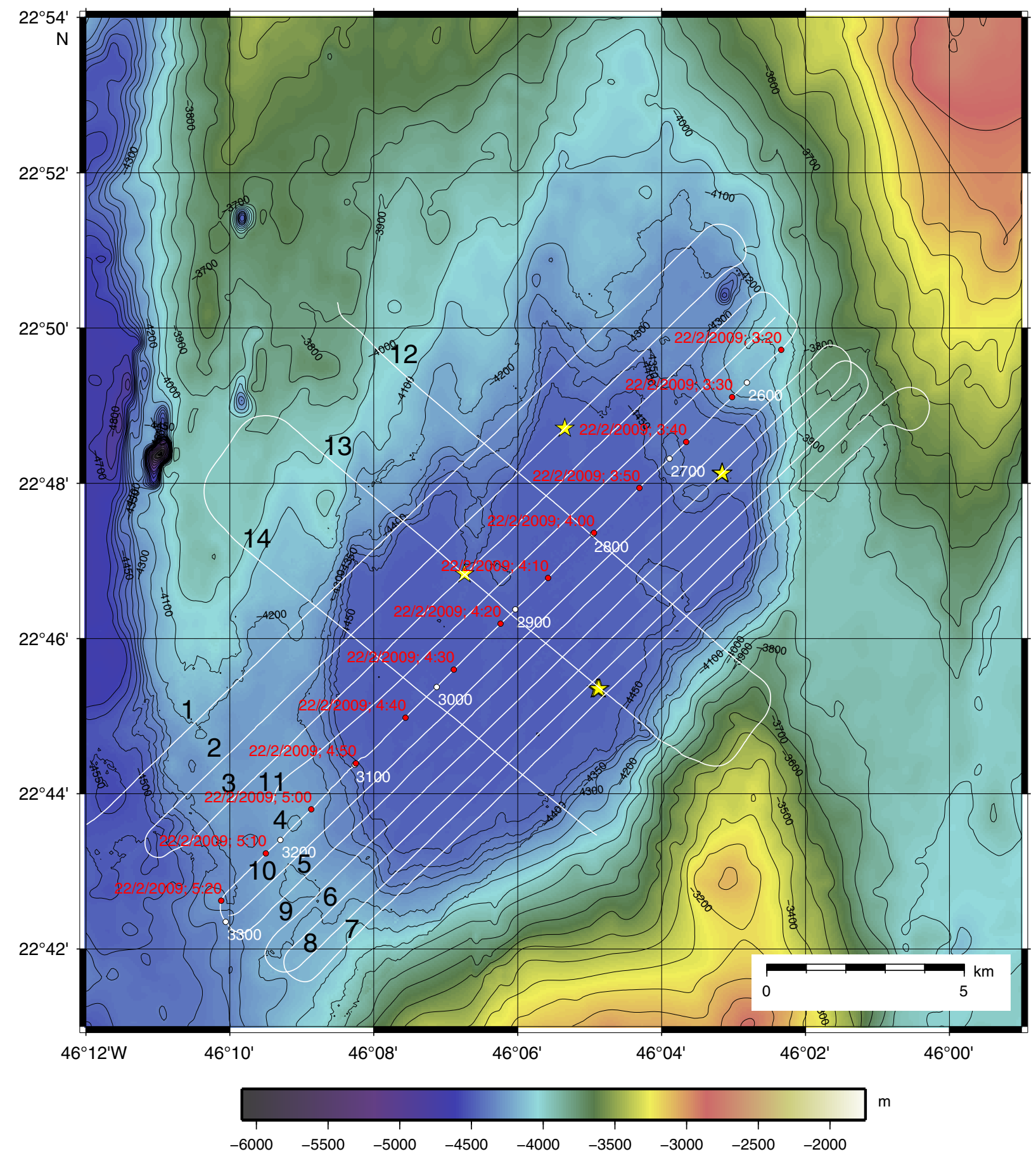


Figure AF11. Parasound record of Profile 4.

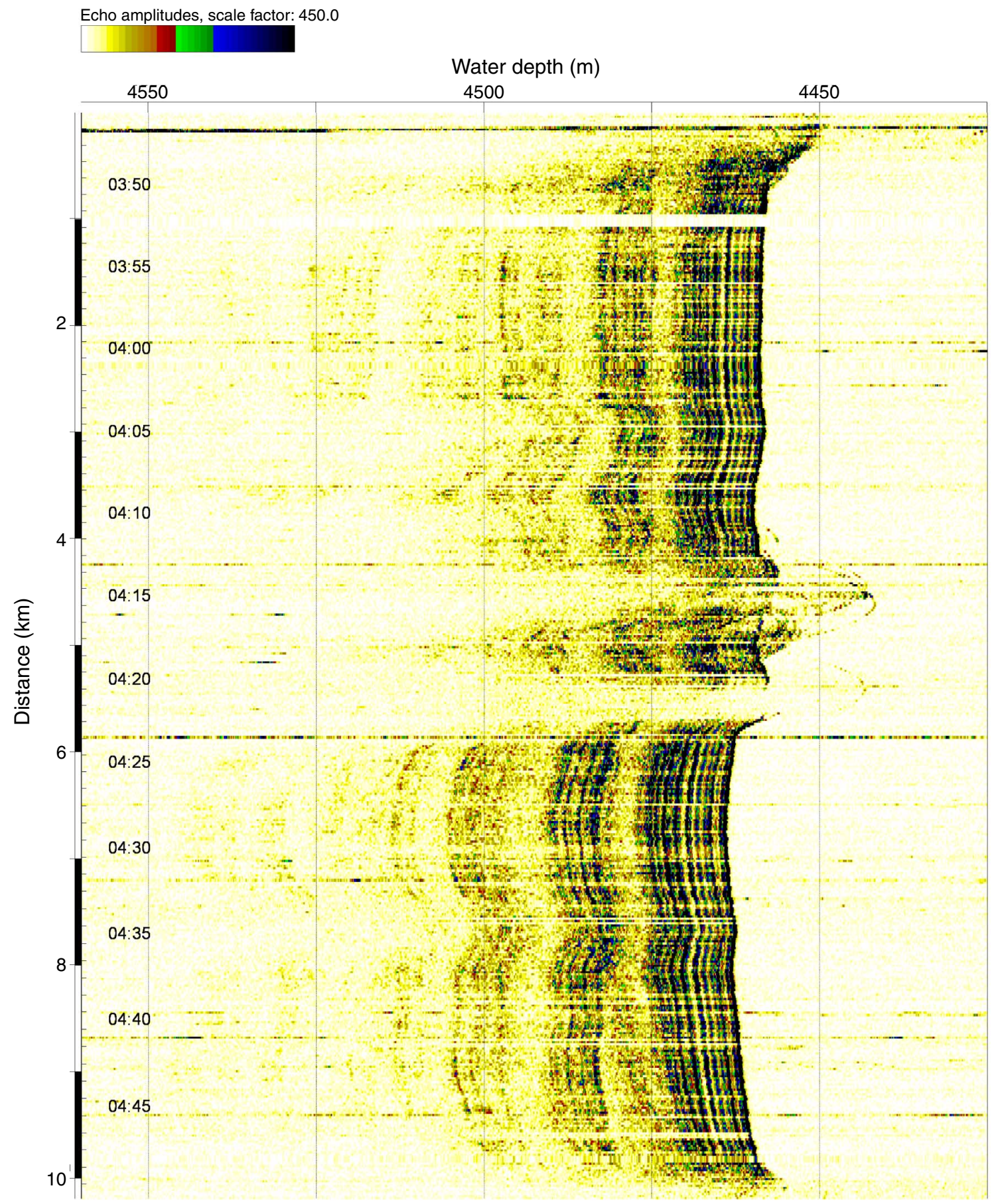


Figure AF12. Seismic record of Profile 4.

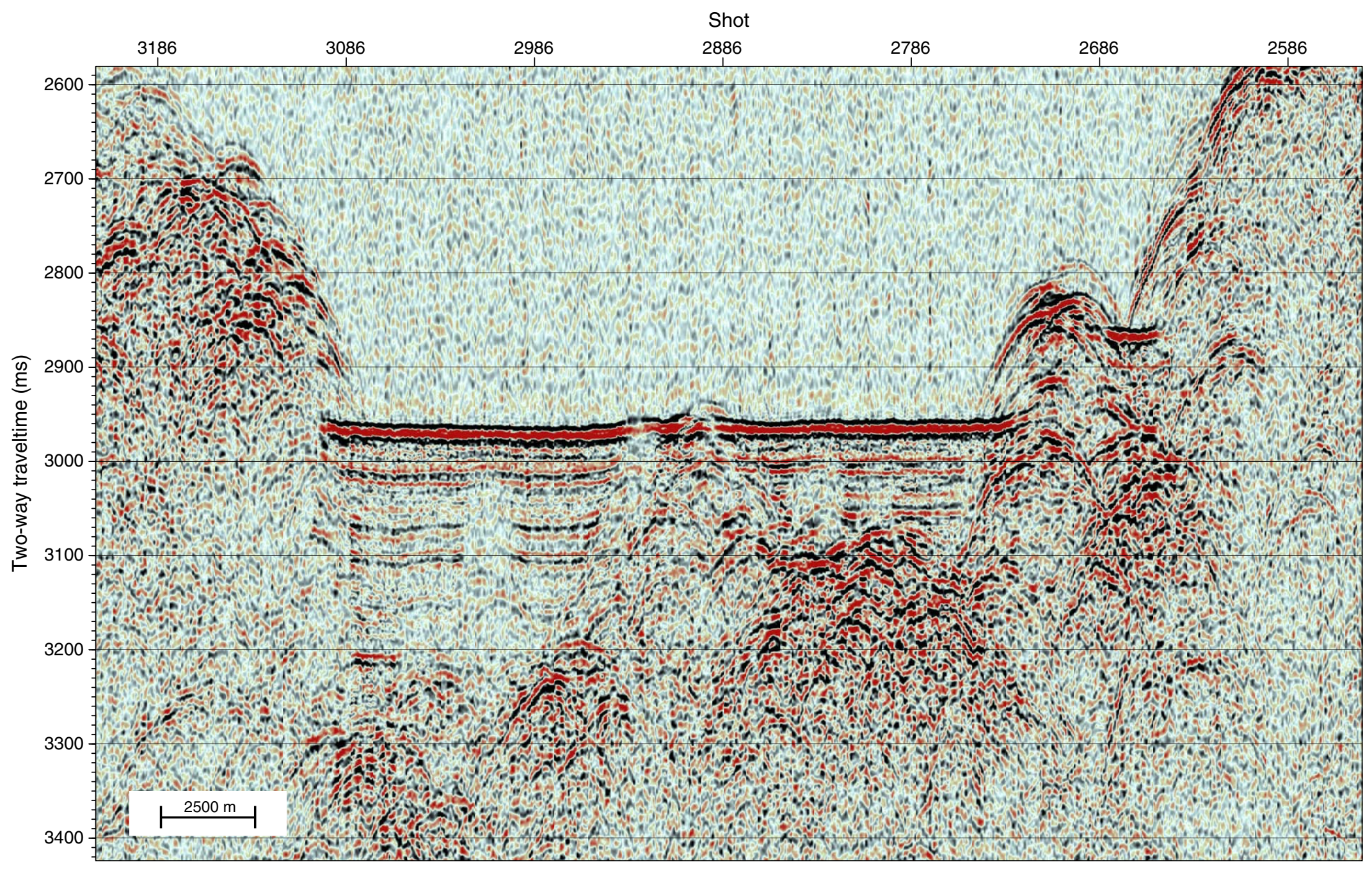


Figure AF13. Map showing shotpoint navigation for seismic and Parasound Profile 5. Stars = positions of DSDP, ODP, and IODP boreholes.

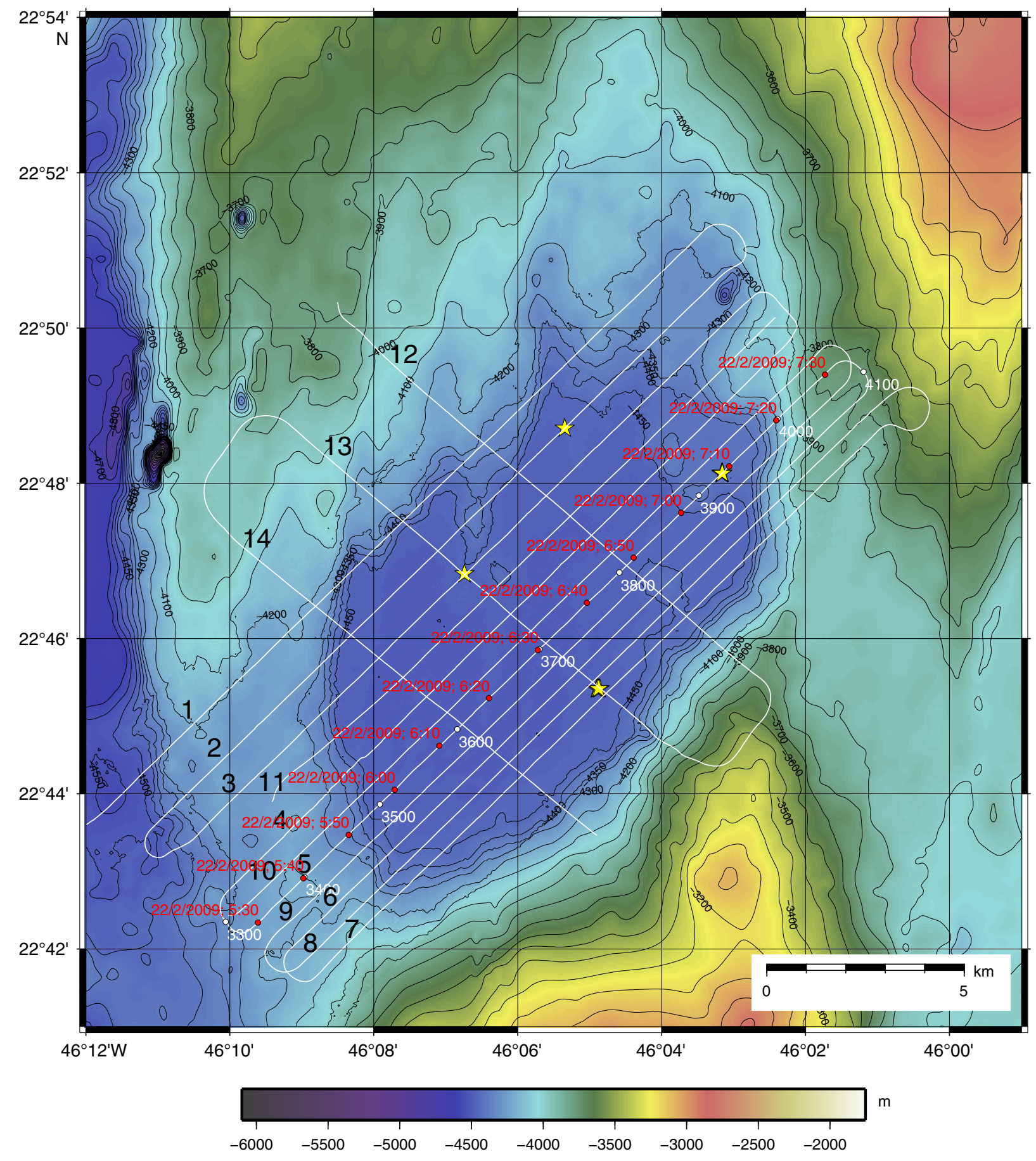


Figure AF14. Parasound record of Profile 5.

Echo amplitudes, scale factor: 450.0

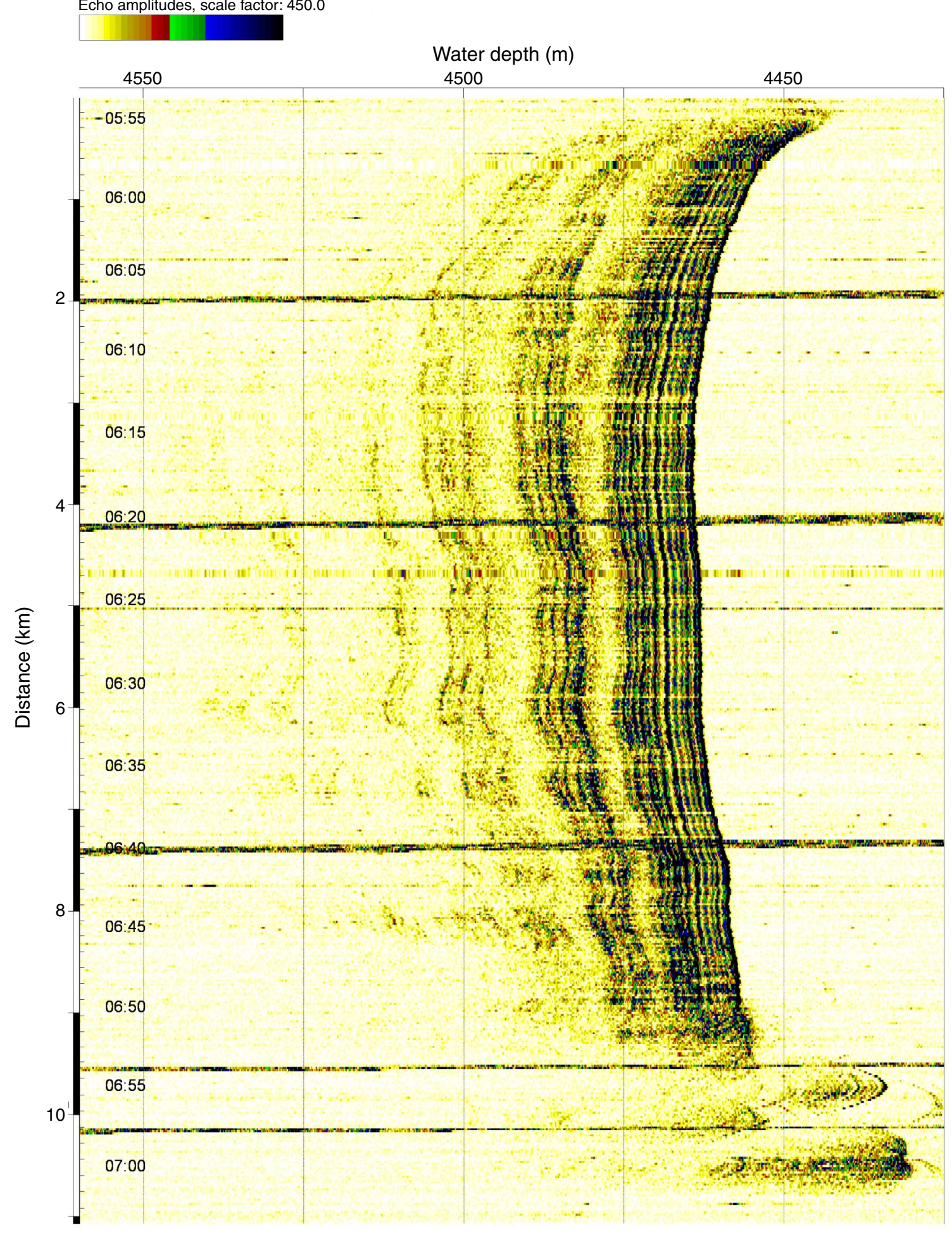


Figure AF15. Seismic record of Profile 5.

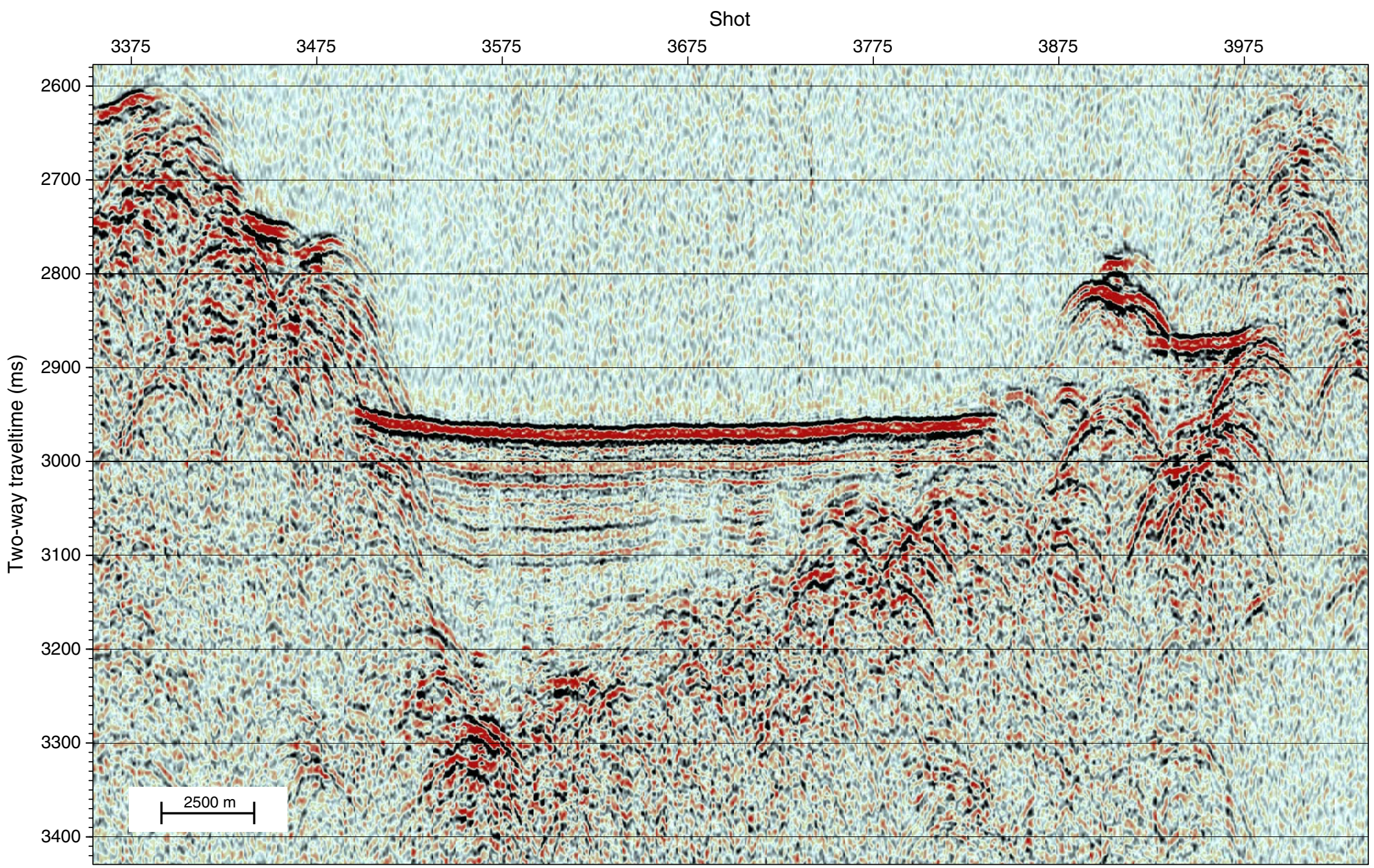


Figure AF16. Map showing shotpoint navigation for seismic and Parasound Profile 6. Stars = positions of DSDP, ODP, and IODP boreholes.

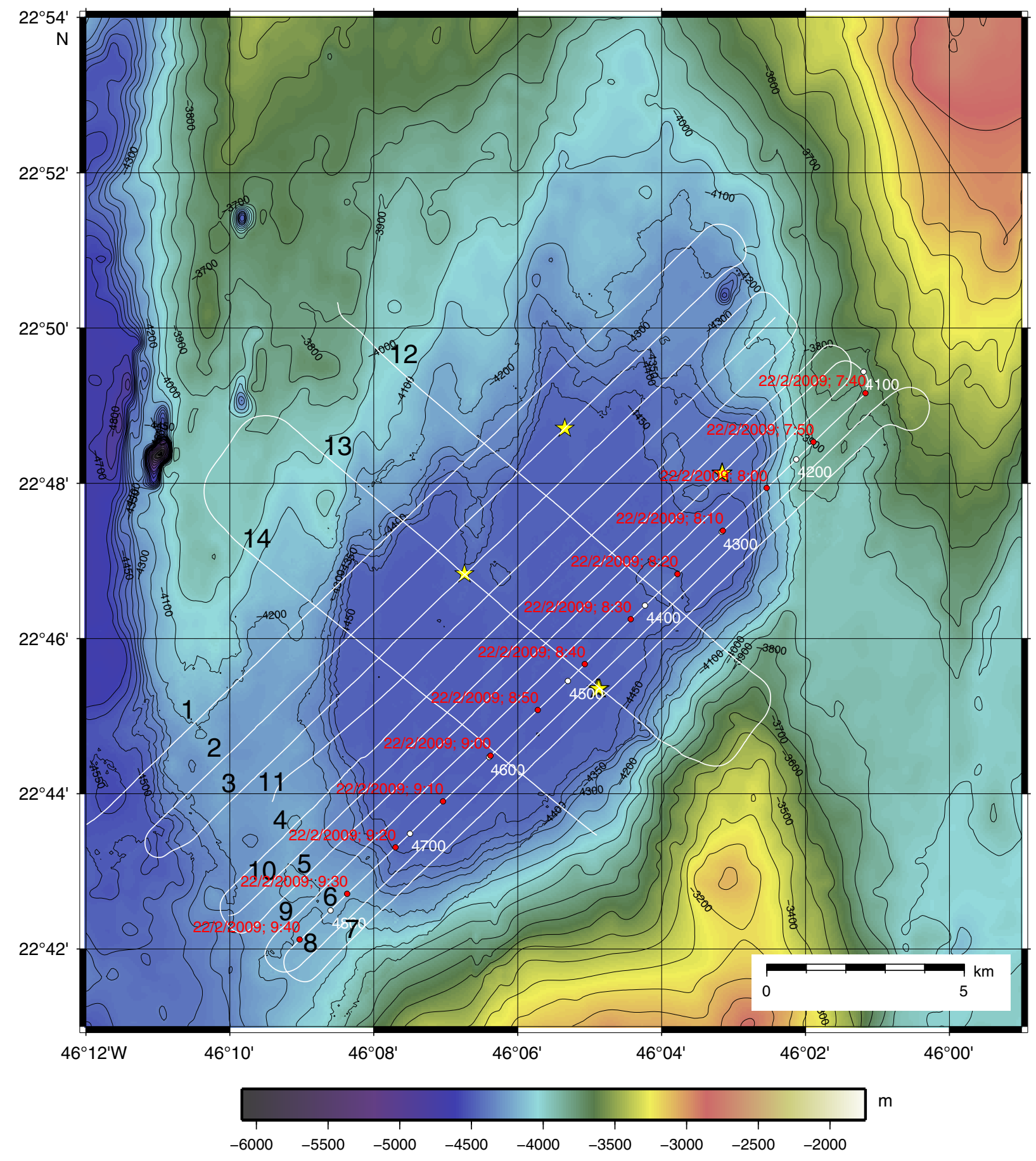


Figure AF17. Parasound record of Profile 6.

Echo amplitudes, scale factor: 450.0

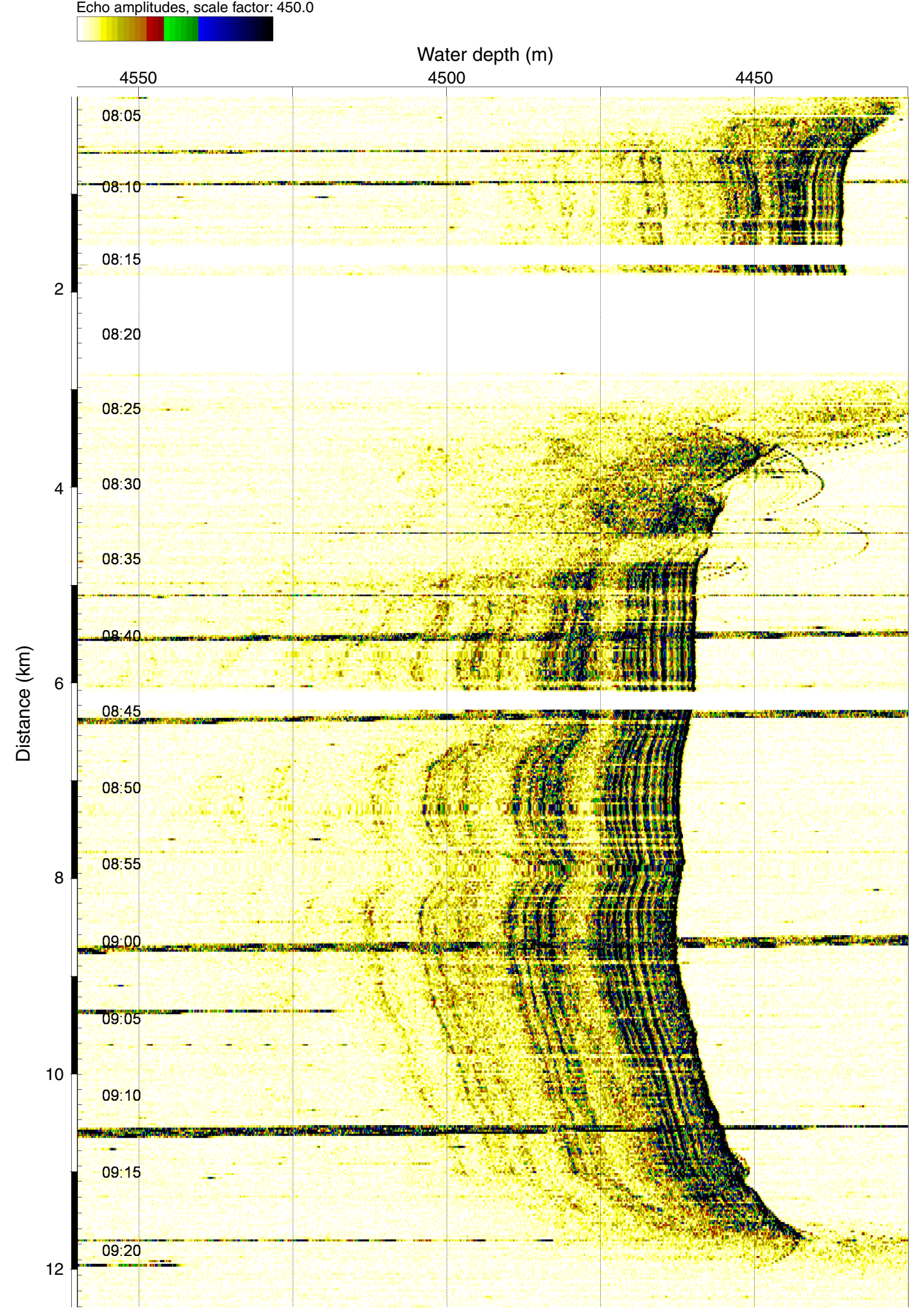


Figure AF18. Seismic record of Profile 6.

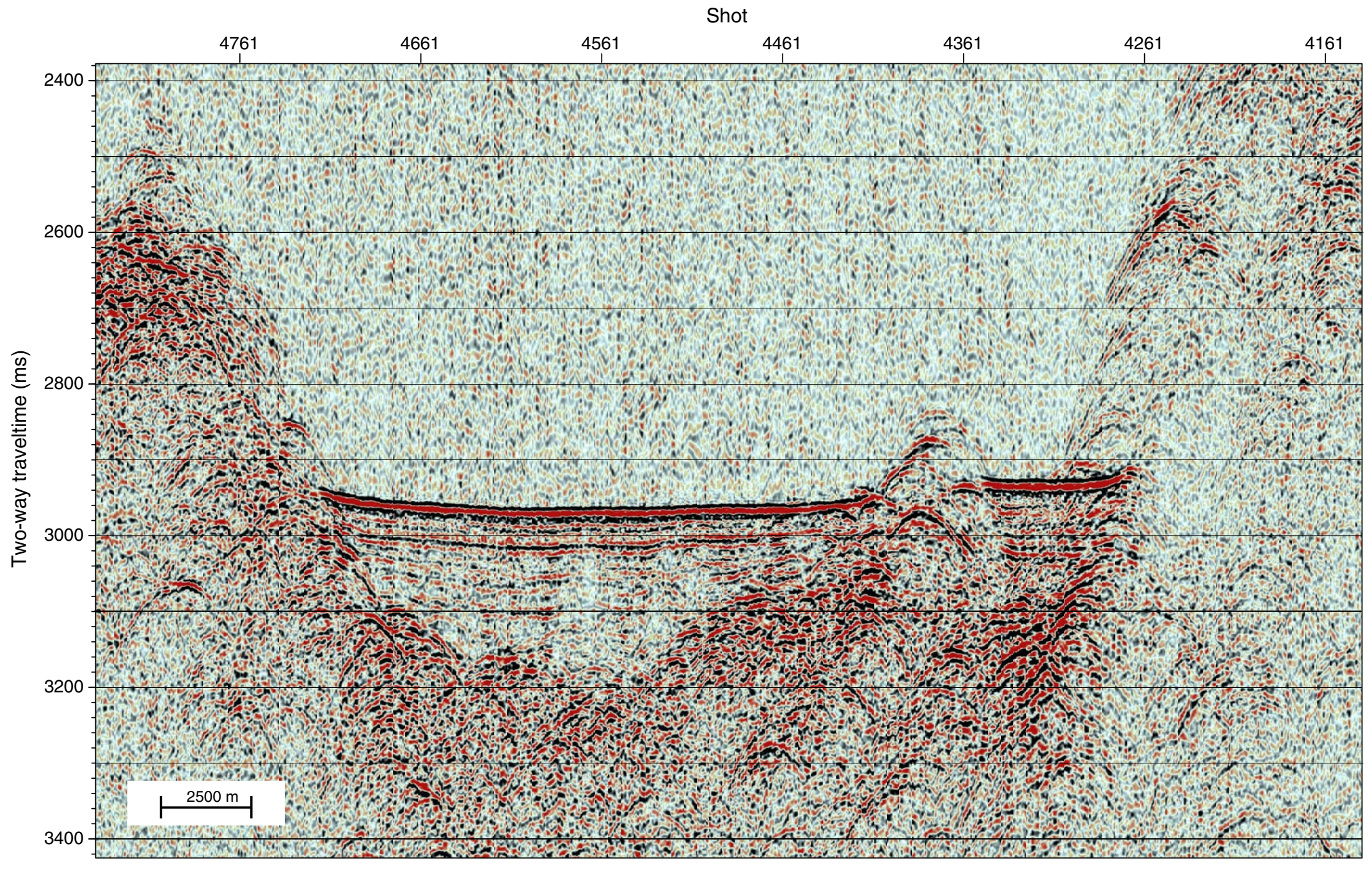


Figure AF19. Map showing shotpoint navigation for seismic and Parasound Profile 7. Stars = positions of DSDP, ODP, and IODP boreholes.

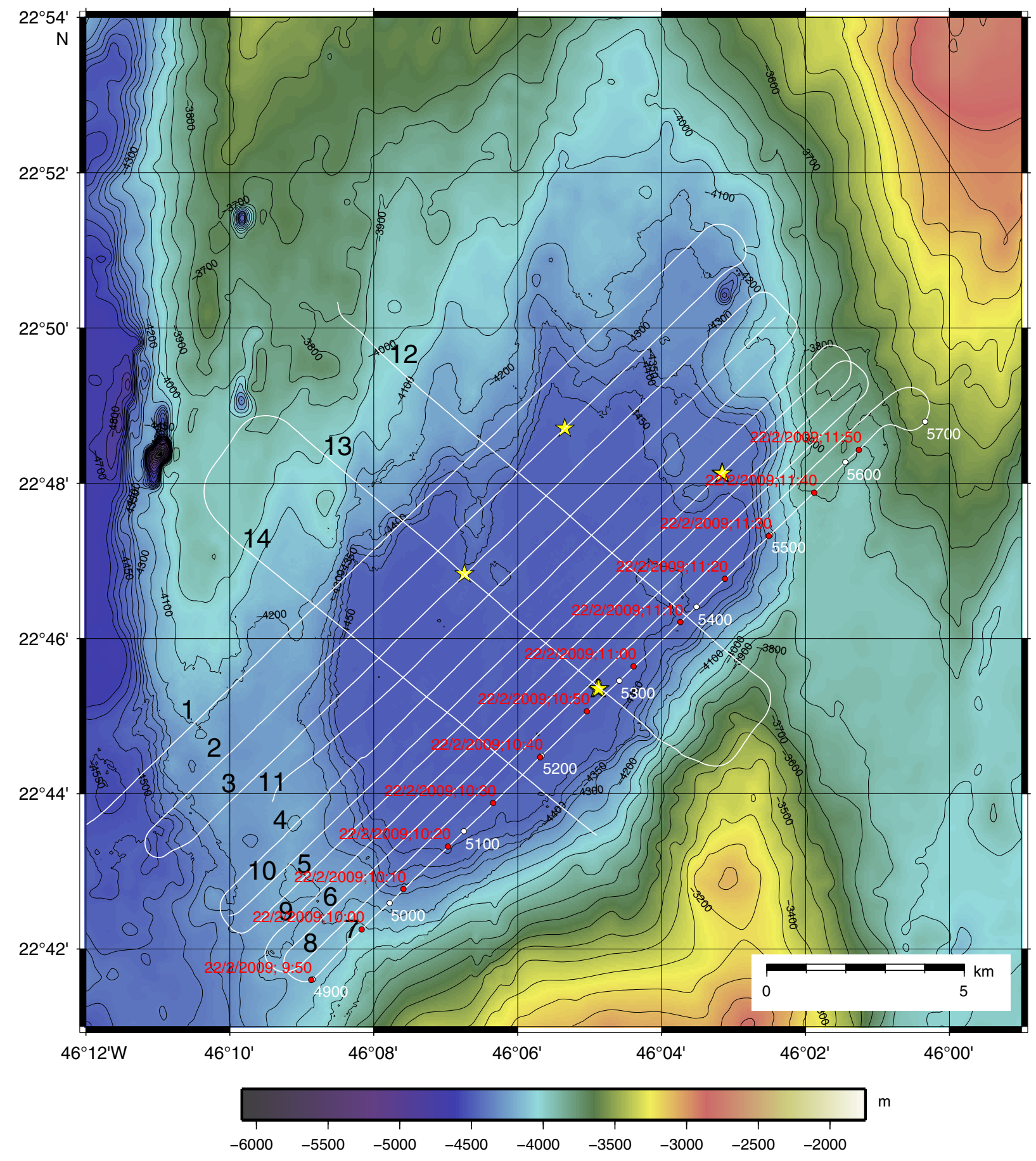


Figure AF20. Parasound record of Profile 7.

Echo amplitudes, scale factor: 450.0

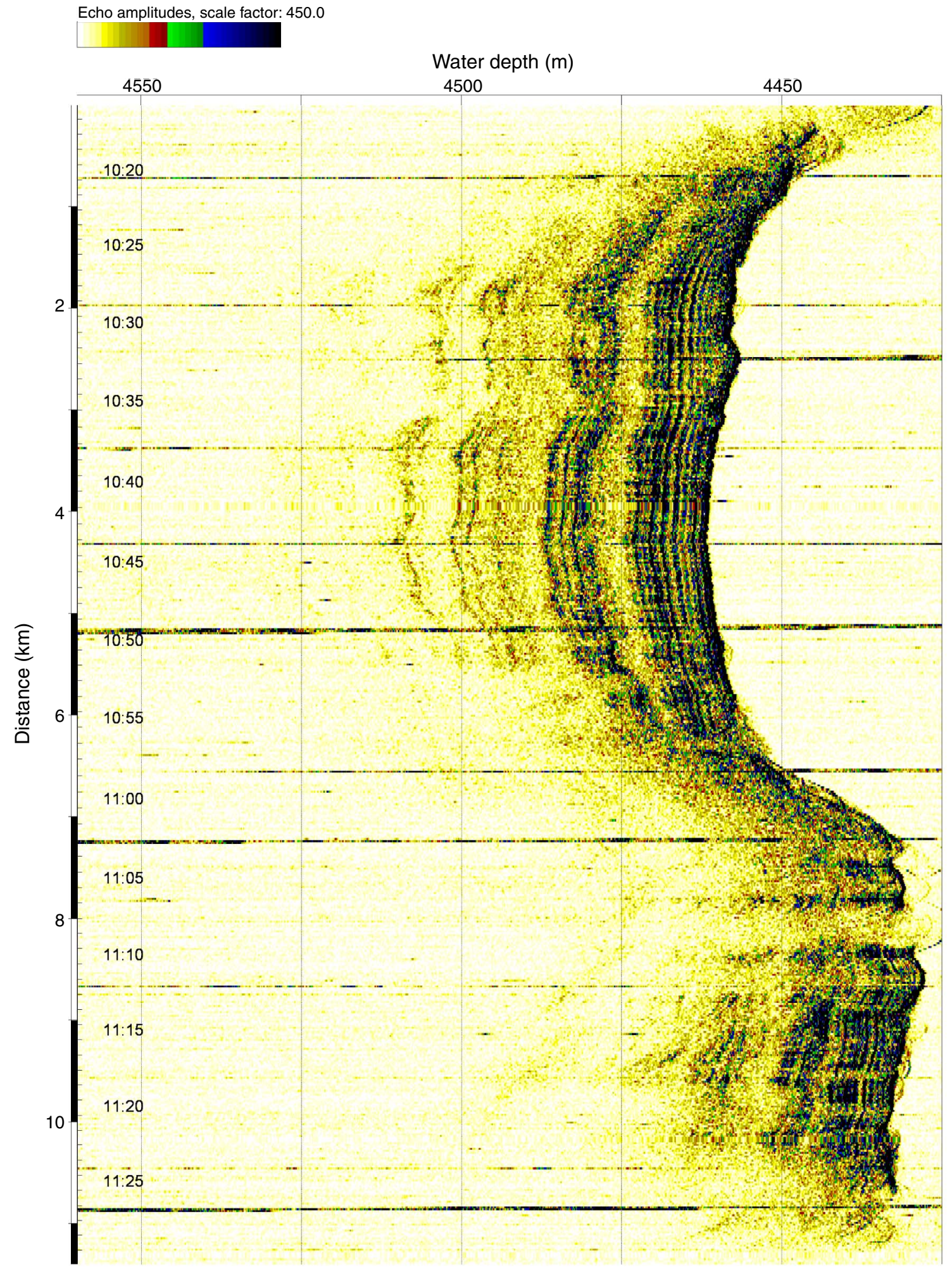


Figure AF21. Seismic record of Profile 7.

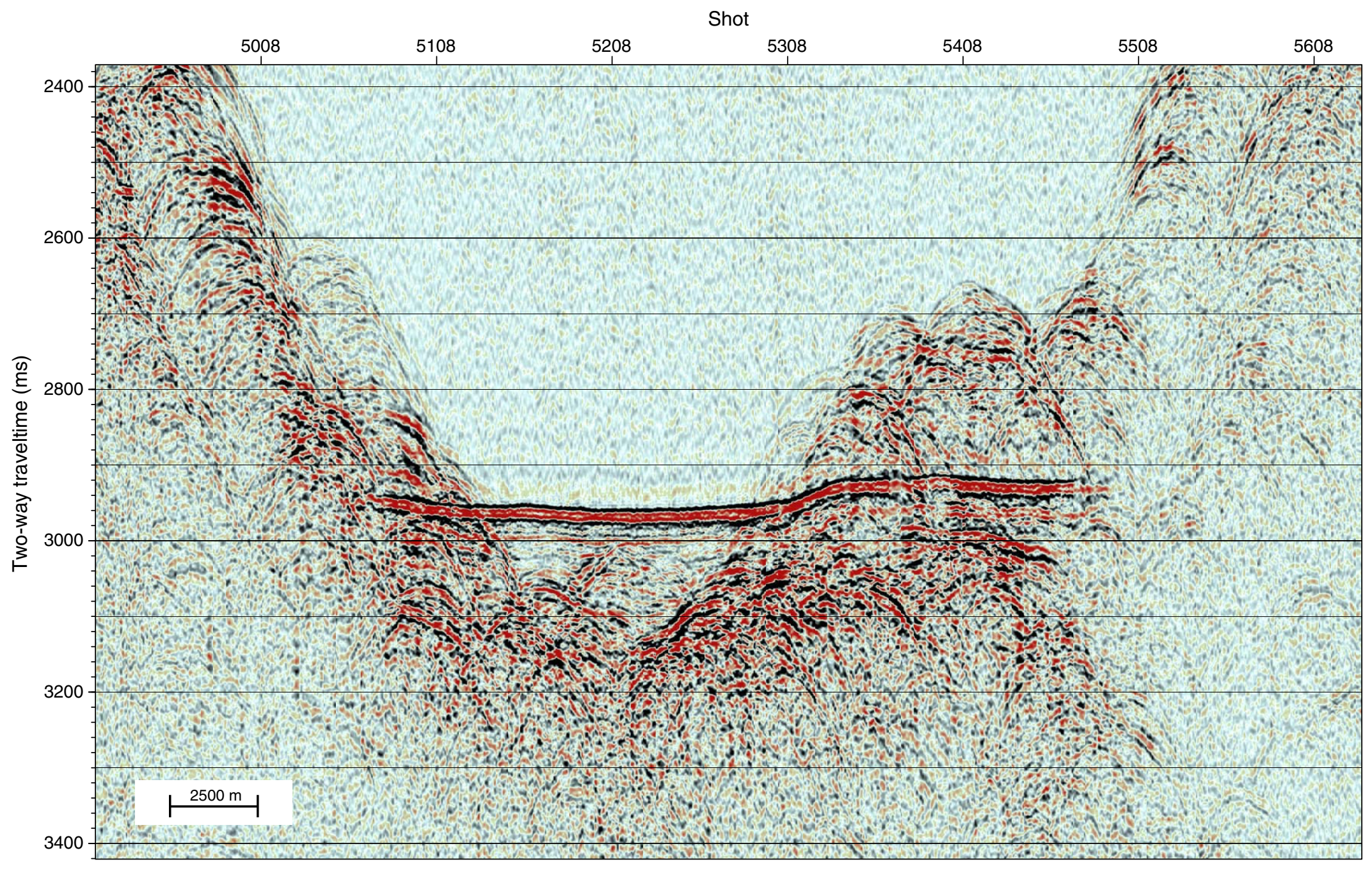


Figure AF22. Map showing shotpoint navigation for seismic and Parasound Profile 8. Stars = positions of DSDP, ODP, and IODP boreholes.

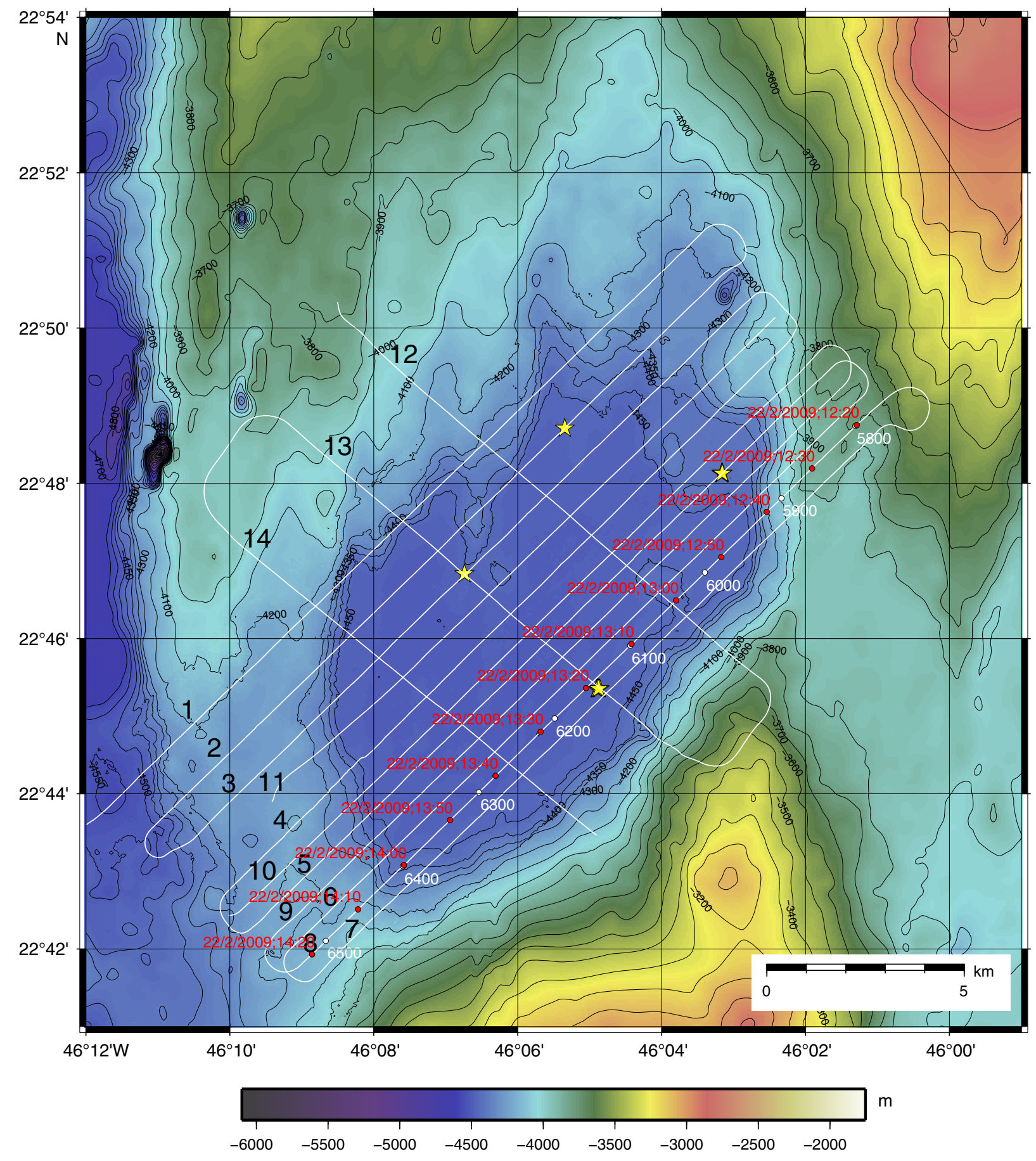


Figure AF23. Parasound record of Profile 8.

Echo amplitudes, scale factor: 450.0

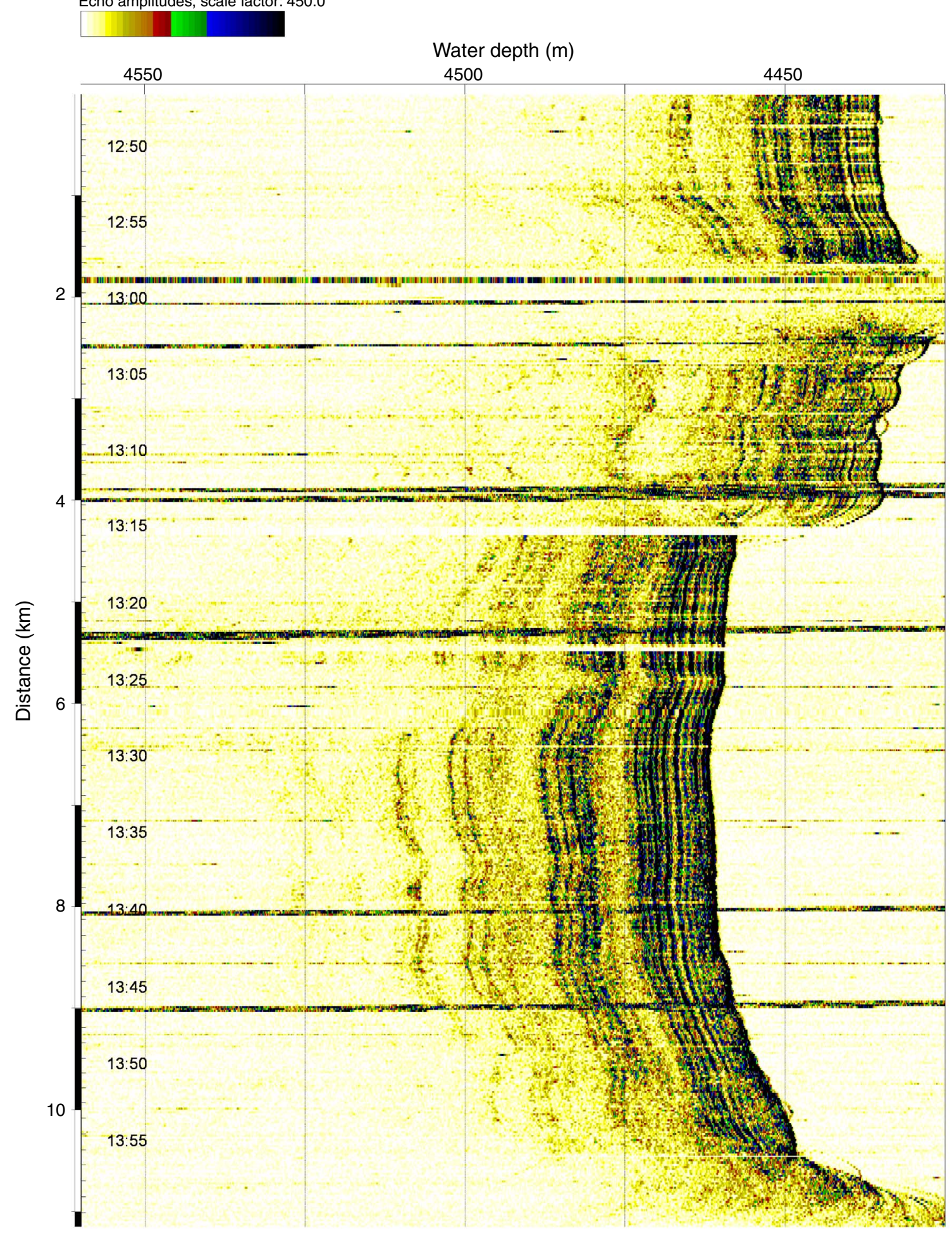


Figure AF24. Seismic record of Profile 8.

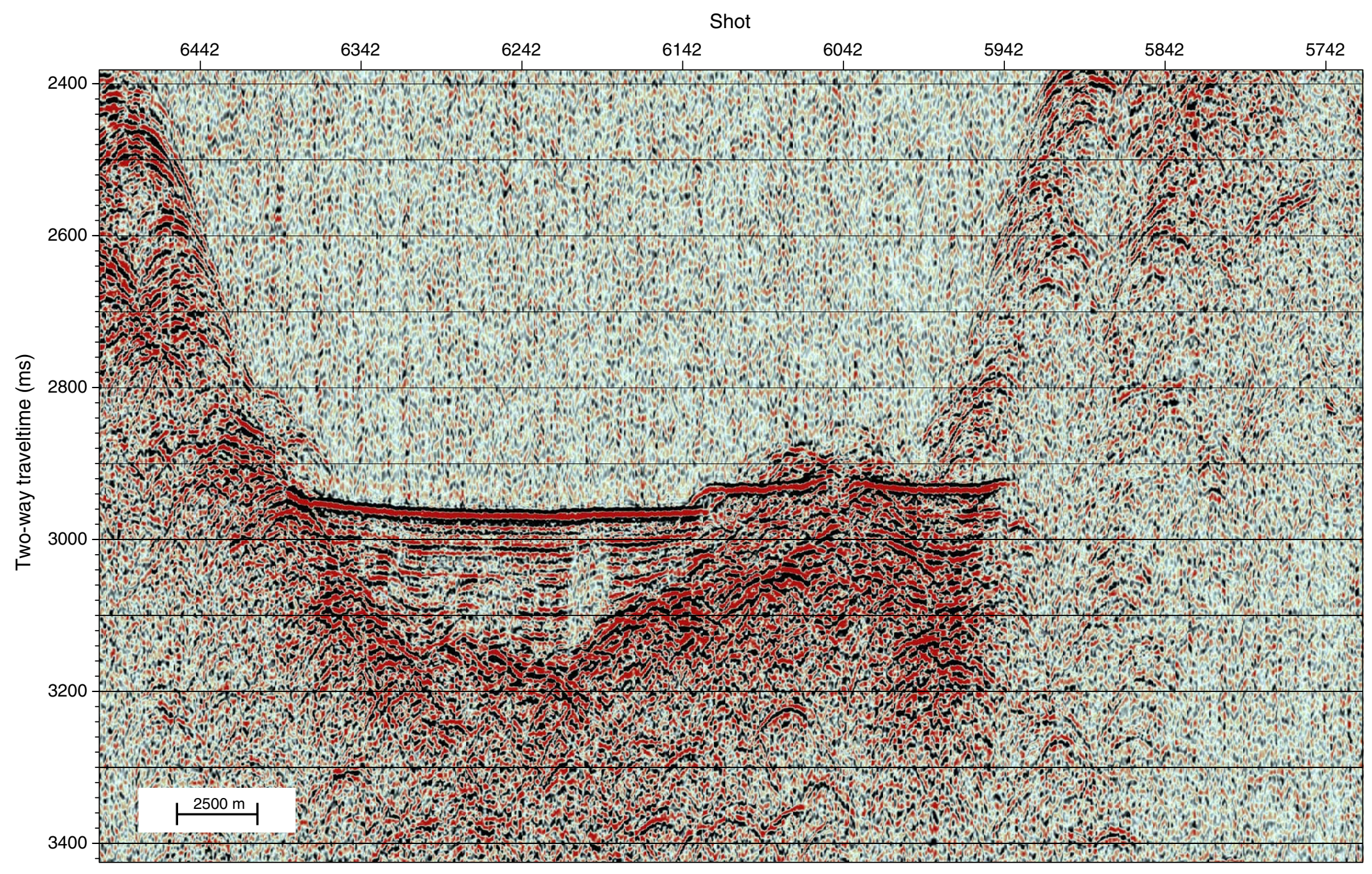


Figure AF25. Map showing shotpoint navigation for seismic and Parasound Profile 9. Stars = positions of DSDP, ODP, and IODP boreholes.

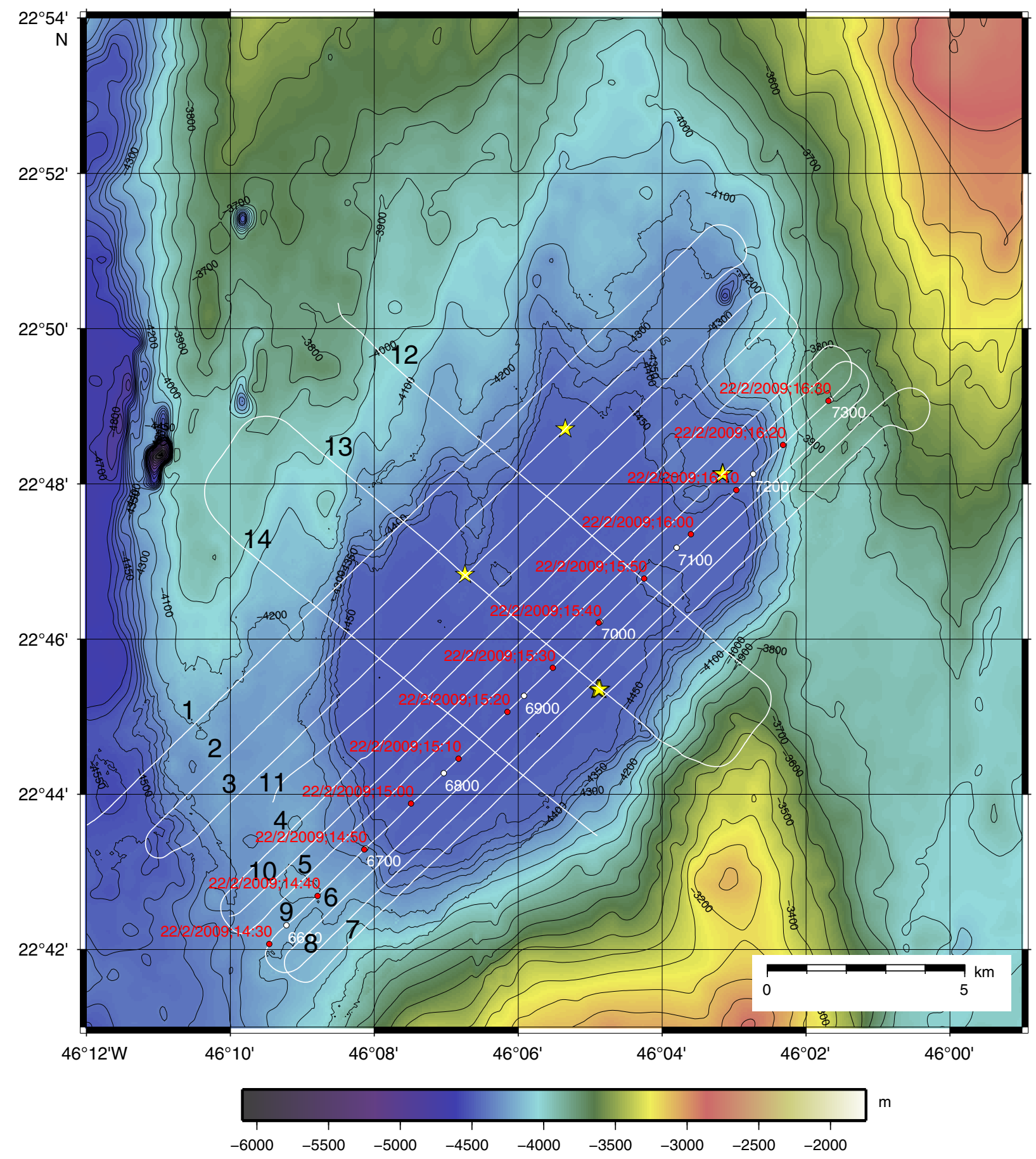


Figure AF26. Parasound record of Profile 9.

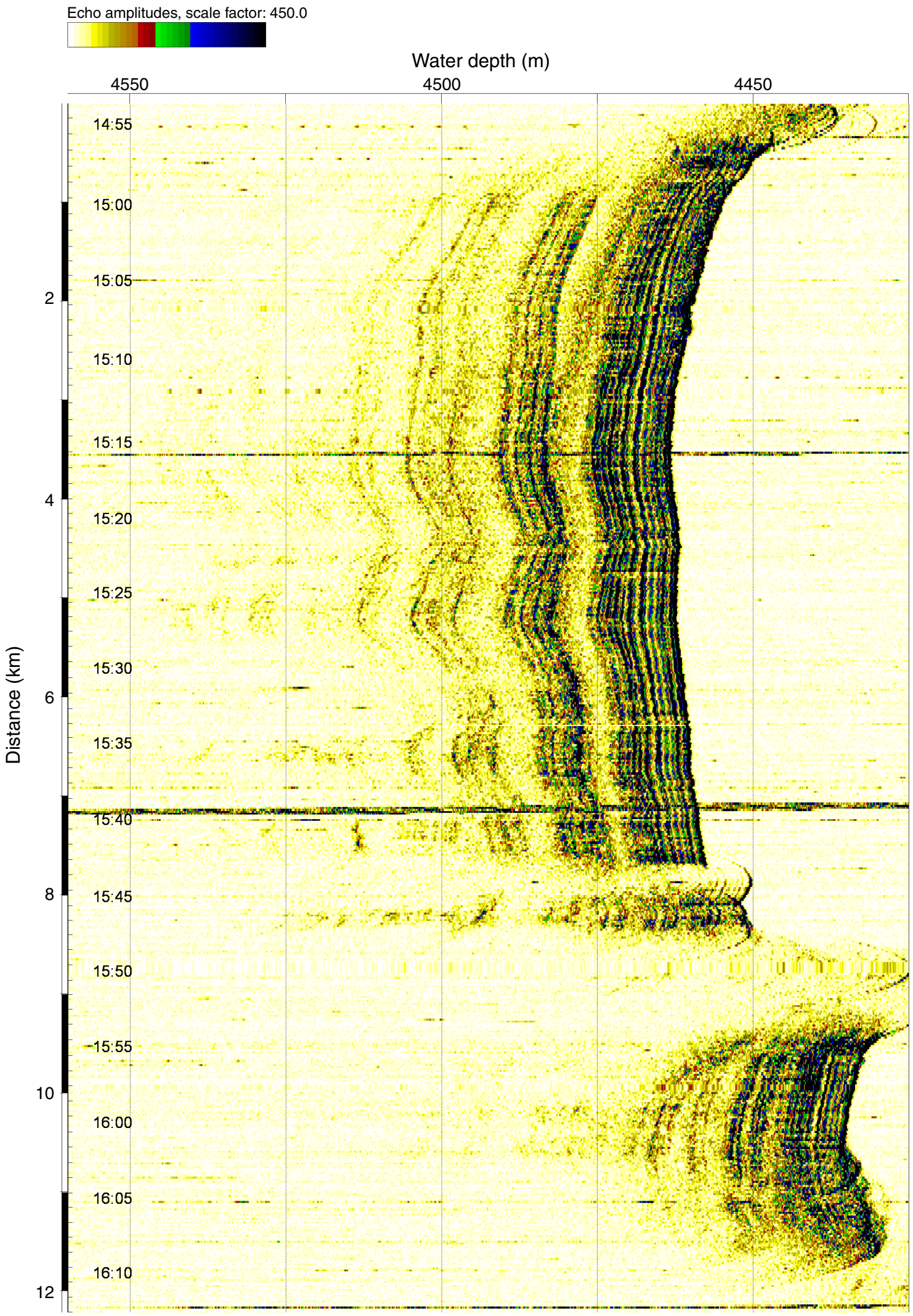


Figure AF27. Seismic record of Profile 9.

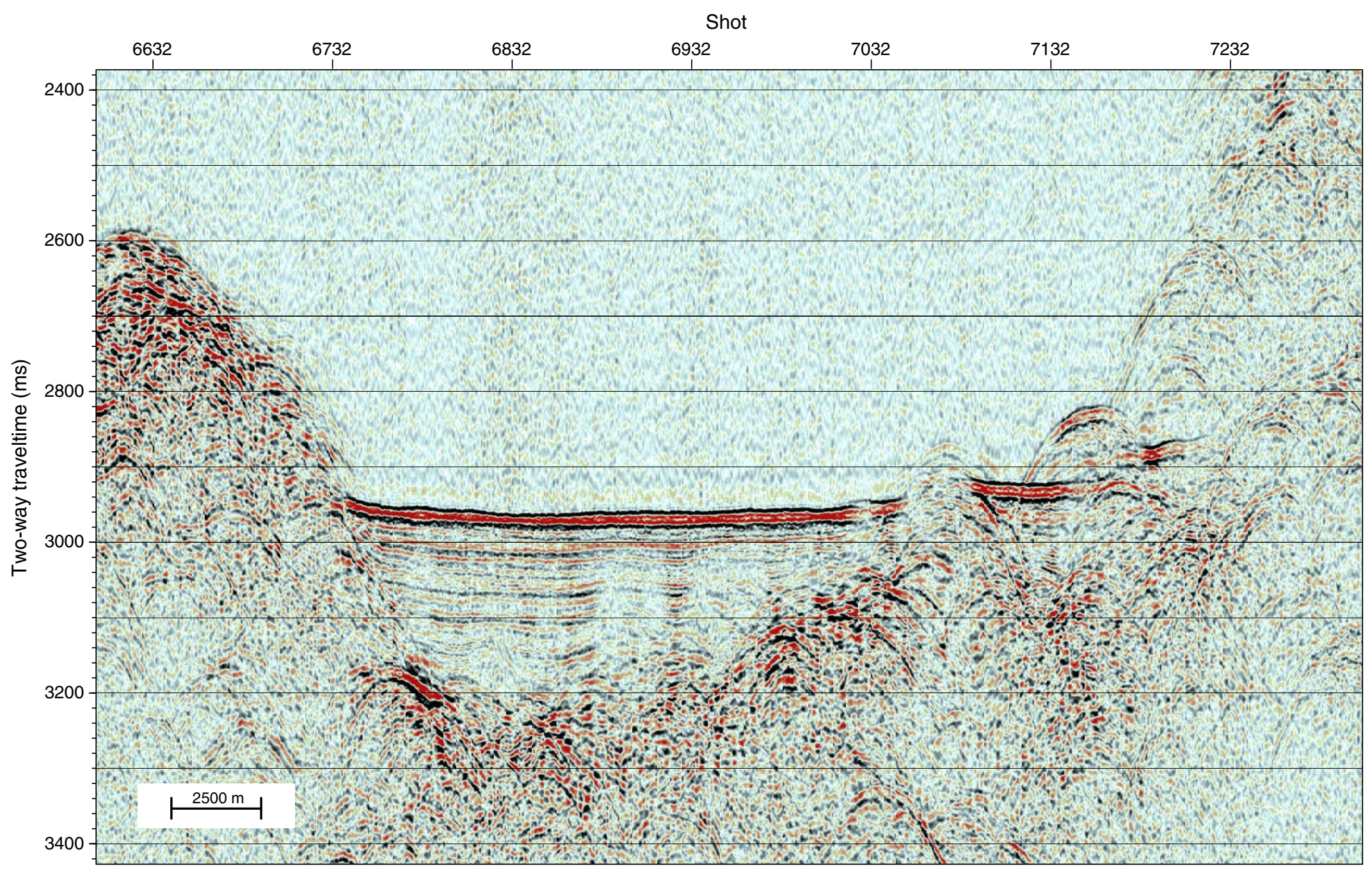


Figure AF28. Map showing shotpoint navigation for seismic and Parasound Profile 10. Stars = positions of DSDP, ODP, and IODP boreholes.

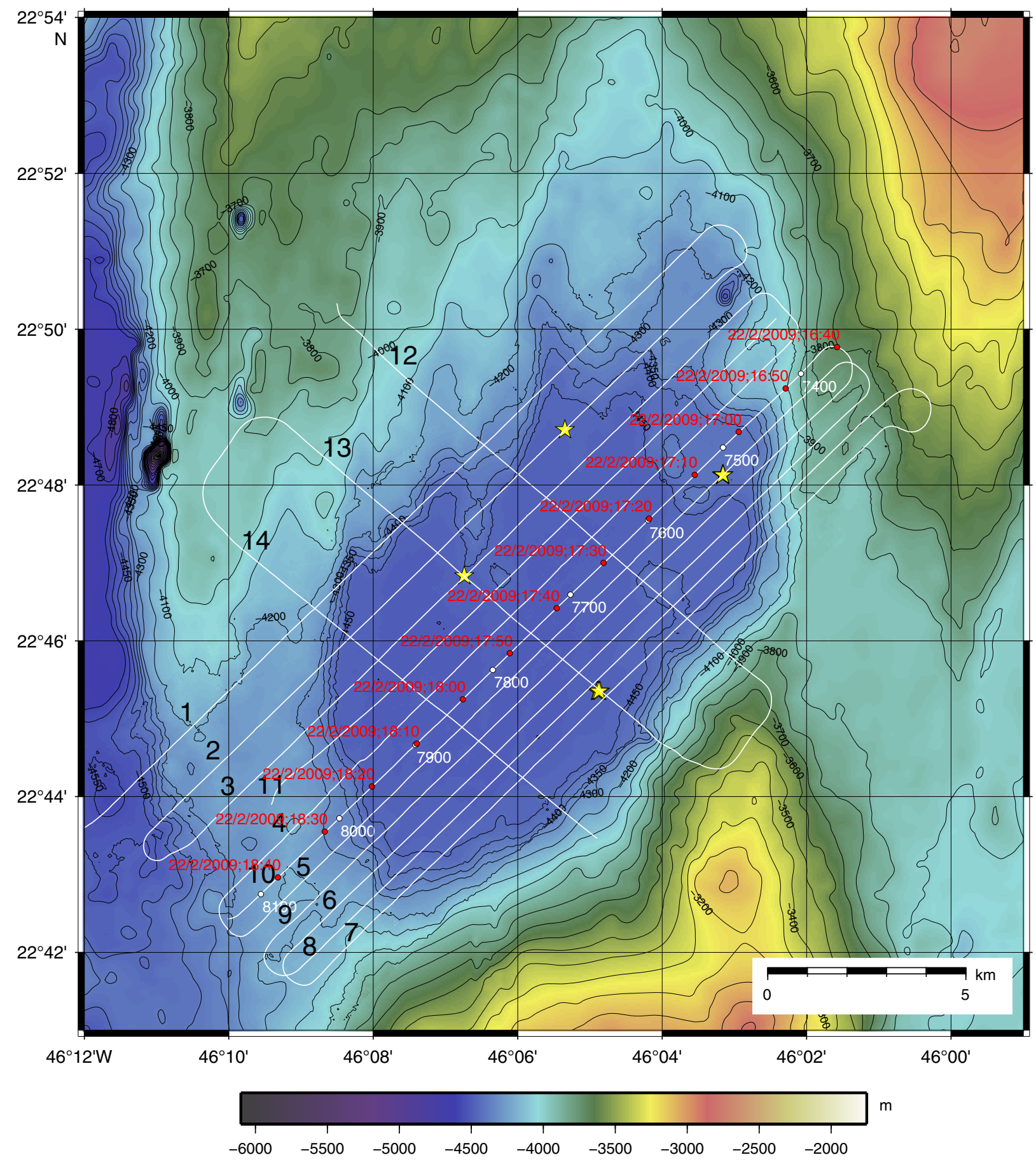


Figure AF29. Parasound record of Profile 10.

Echo amplitudes, scale factor: 450.0

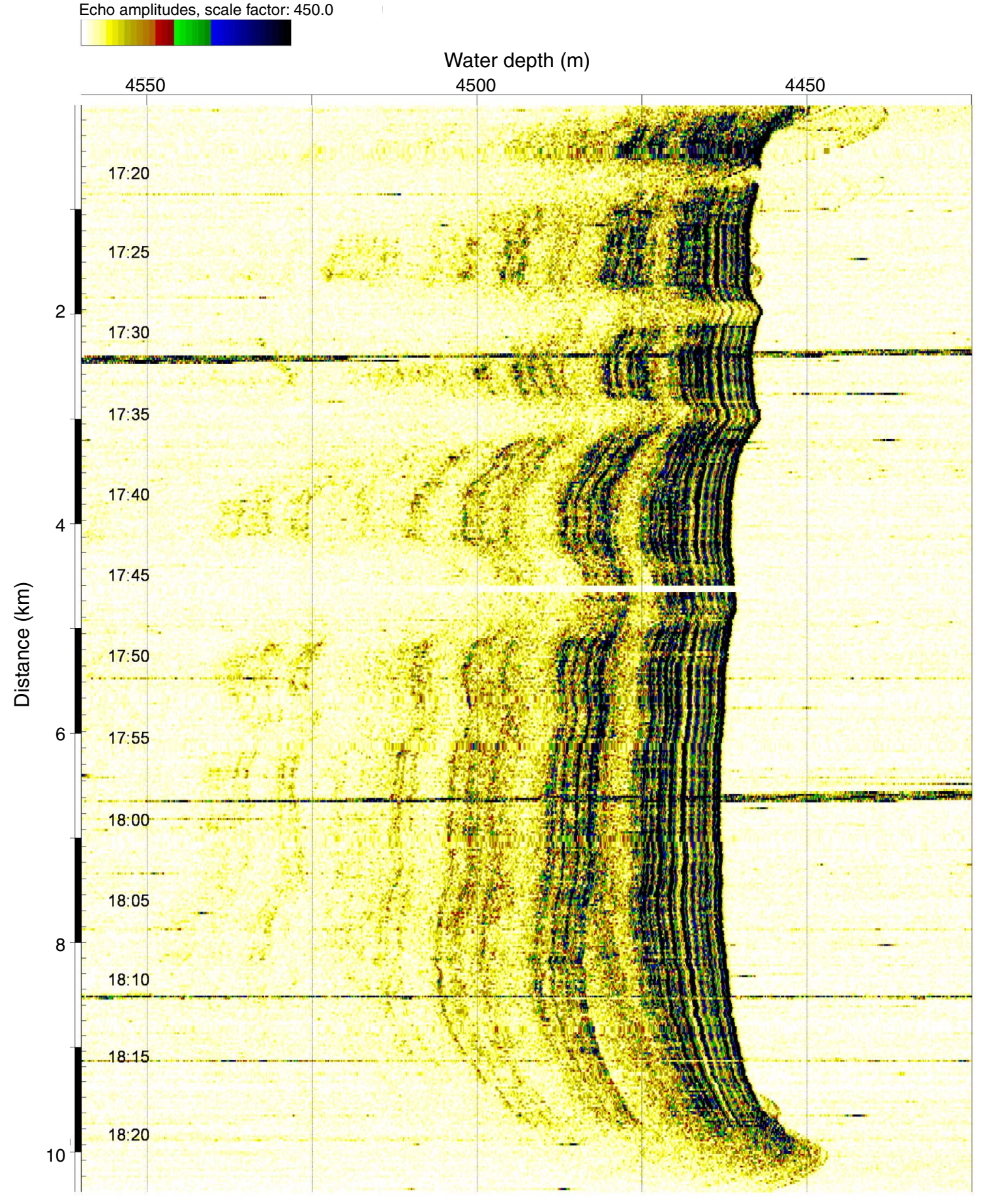


Figure AF30. Seismic record of Profile 10.

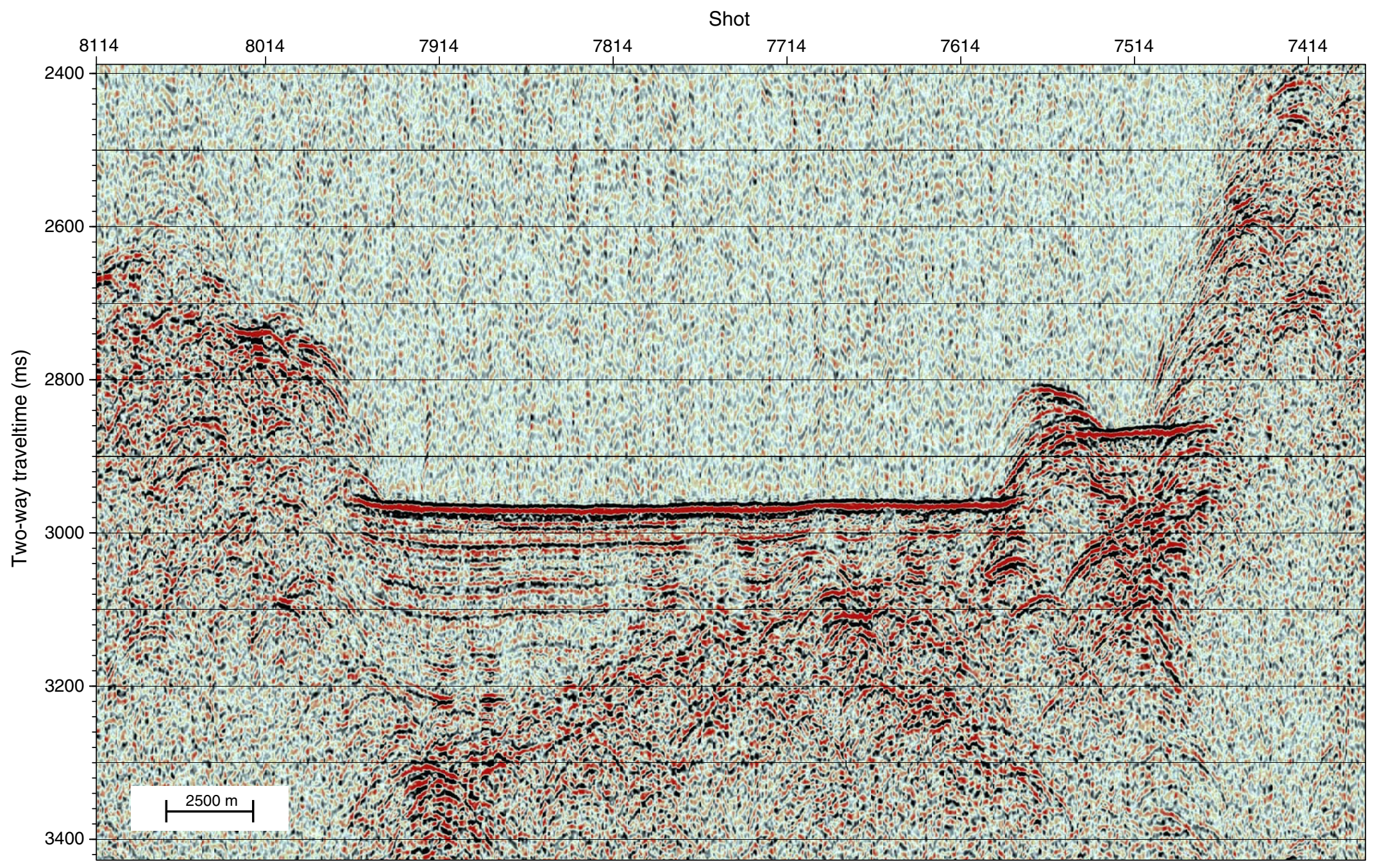


Figure AF31. Map showing shotpoint navigation for seismic and Parasound Profile 11. Stars = positions of DSDP, ODP, and IODP boreholes.

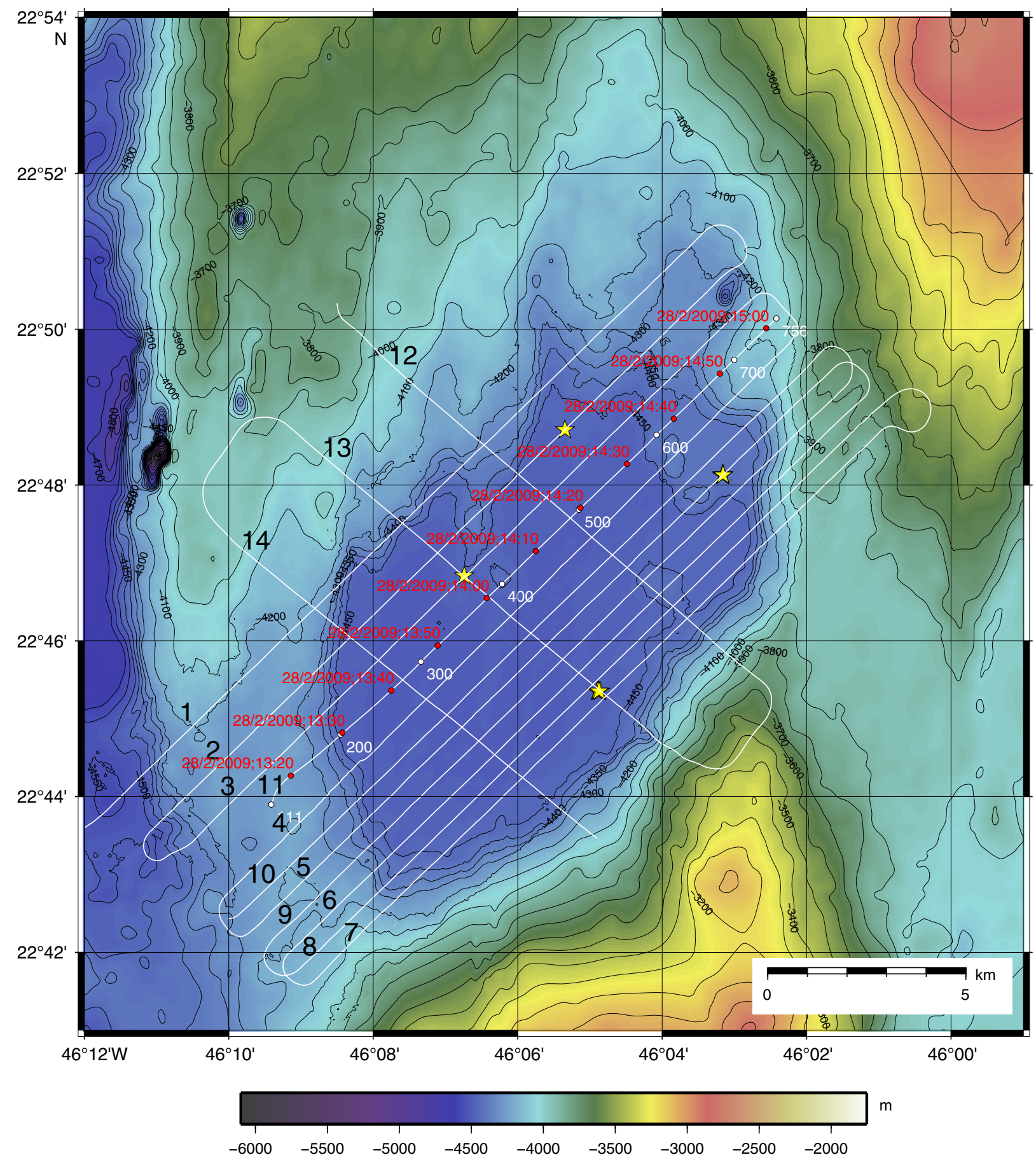


Figure AF32. Parasound record of Profile 11.

Echo amplitudes, scale factor: 450.0

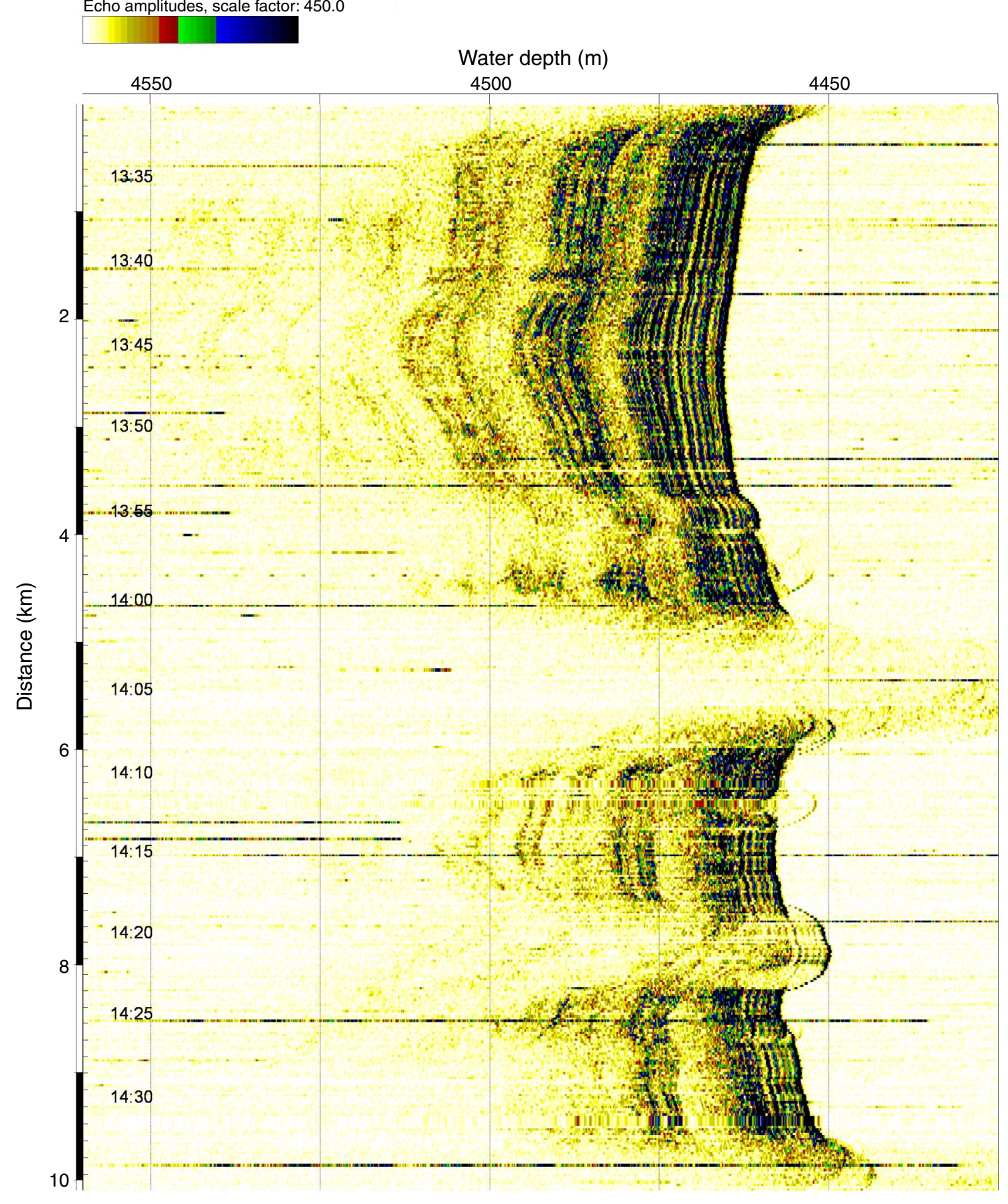


Figure AF33. Seismic record of Profile 11.

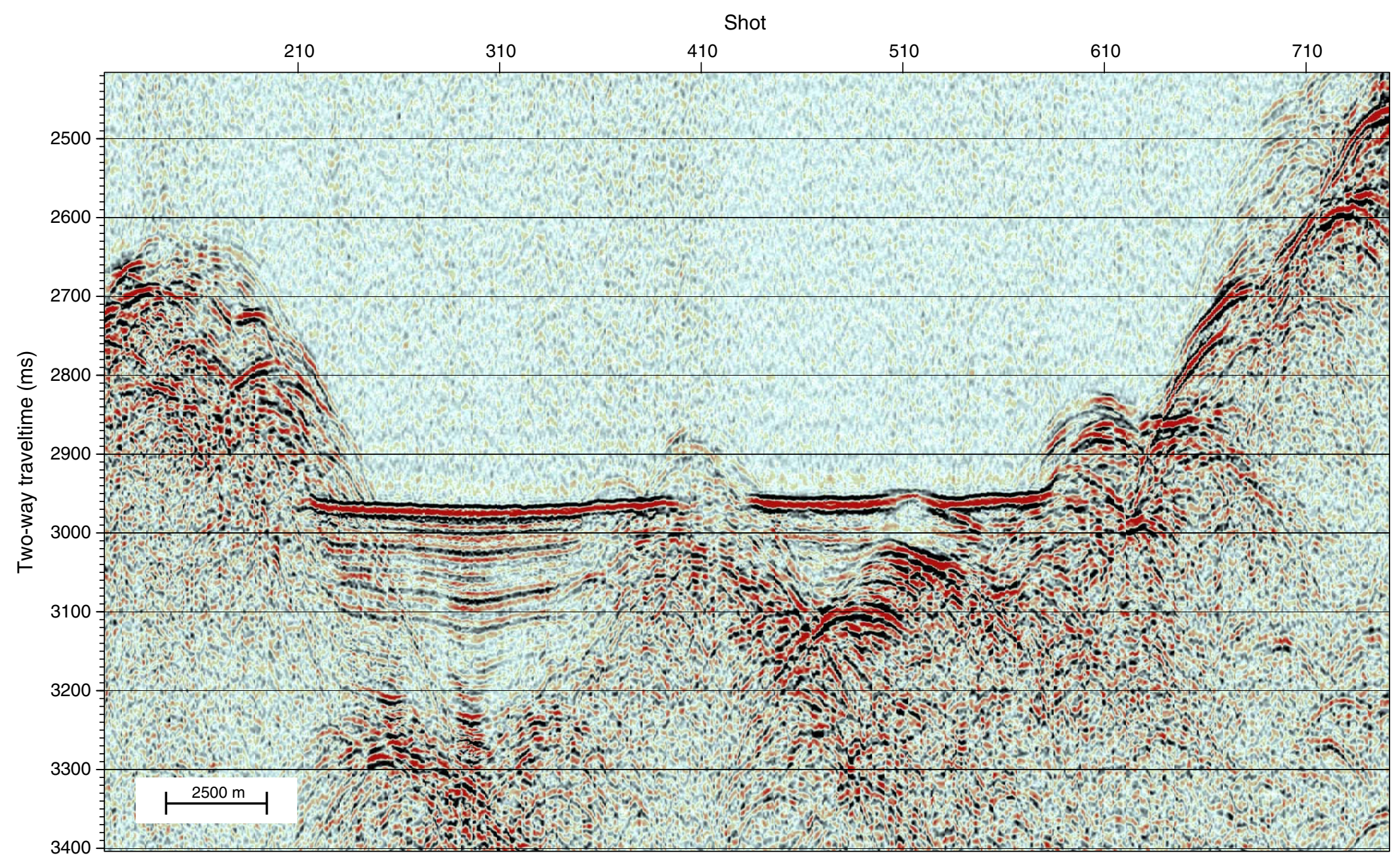


Figure AF34. Map showing shotpoint navigation for seismic and Parasound Profile 12. Stars = positions of DSDP, ODP, and IODP boreholes.

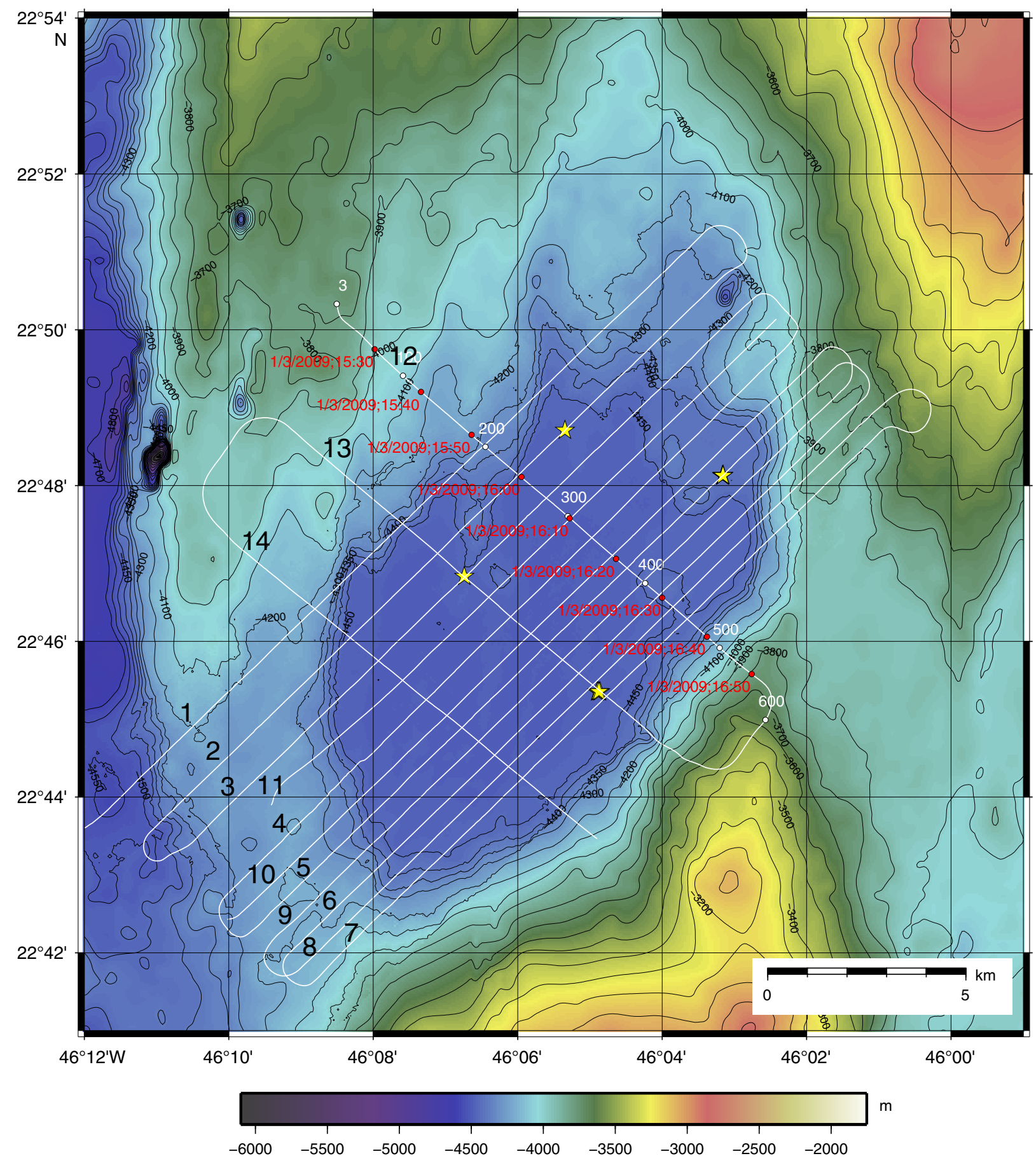


Figure AF35. Parasound record of Profile 12.

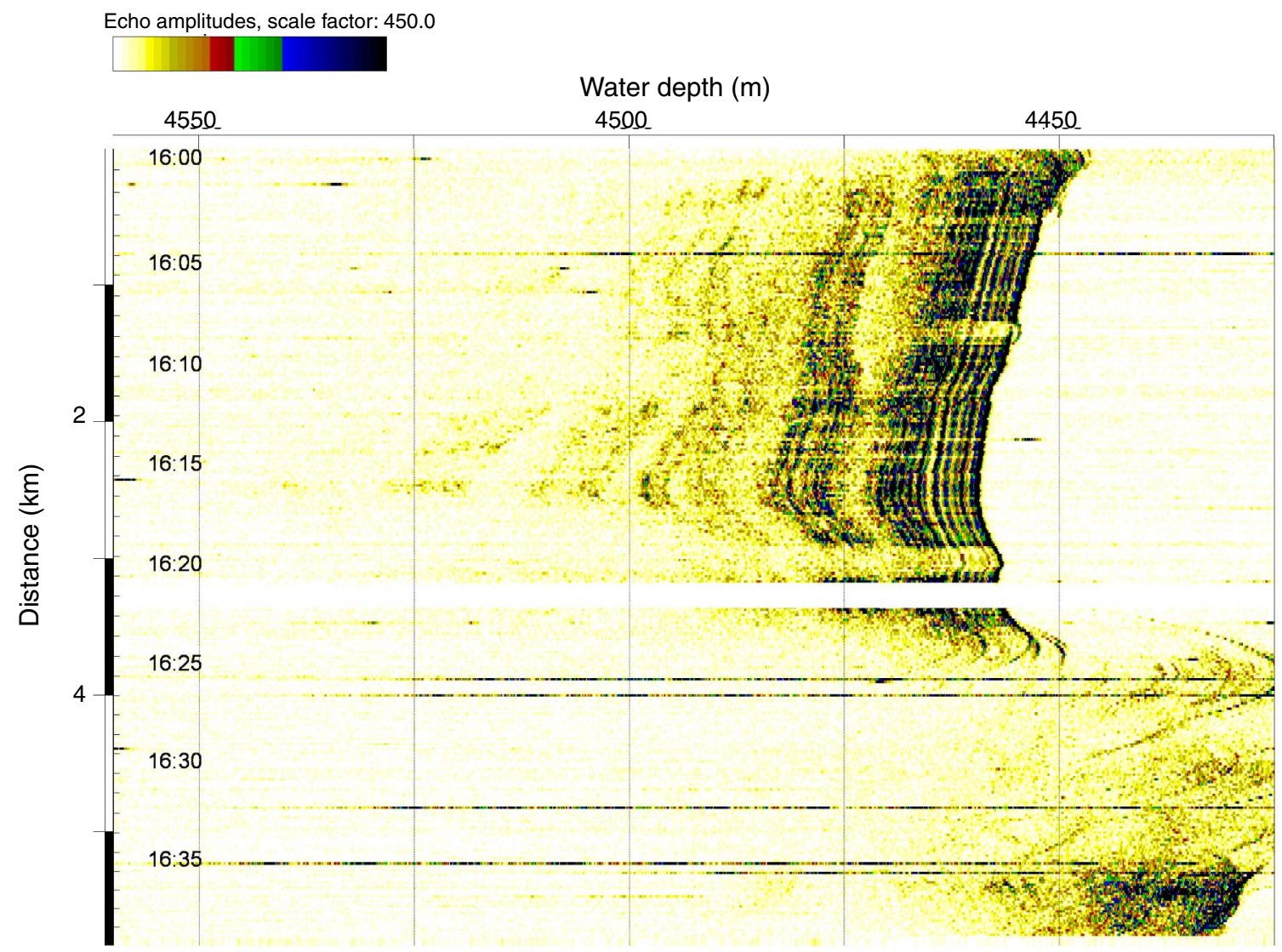


Figure AF36. Seismic record of Profile 12. 
Figure AF37. Map showing shotpoint navigation for seismic and Parasound Profile 13. Stars = positions of DSDP, ODP, and IODP boreholes.

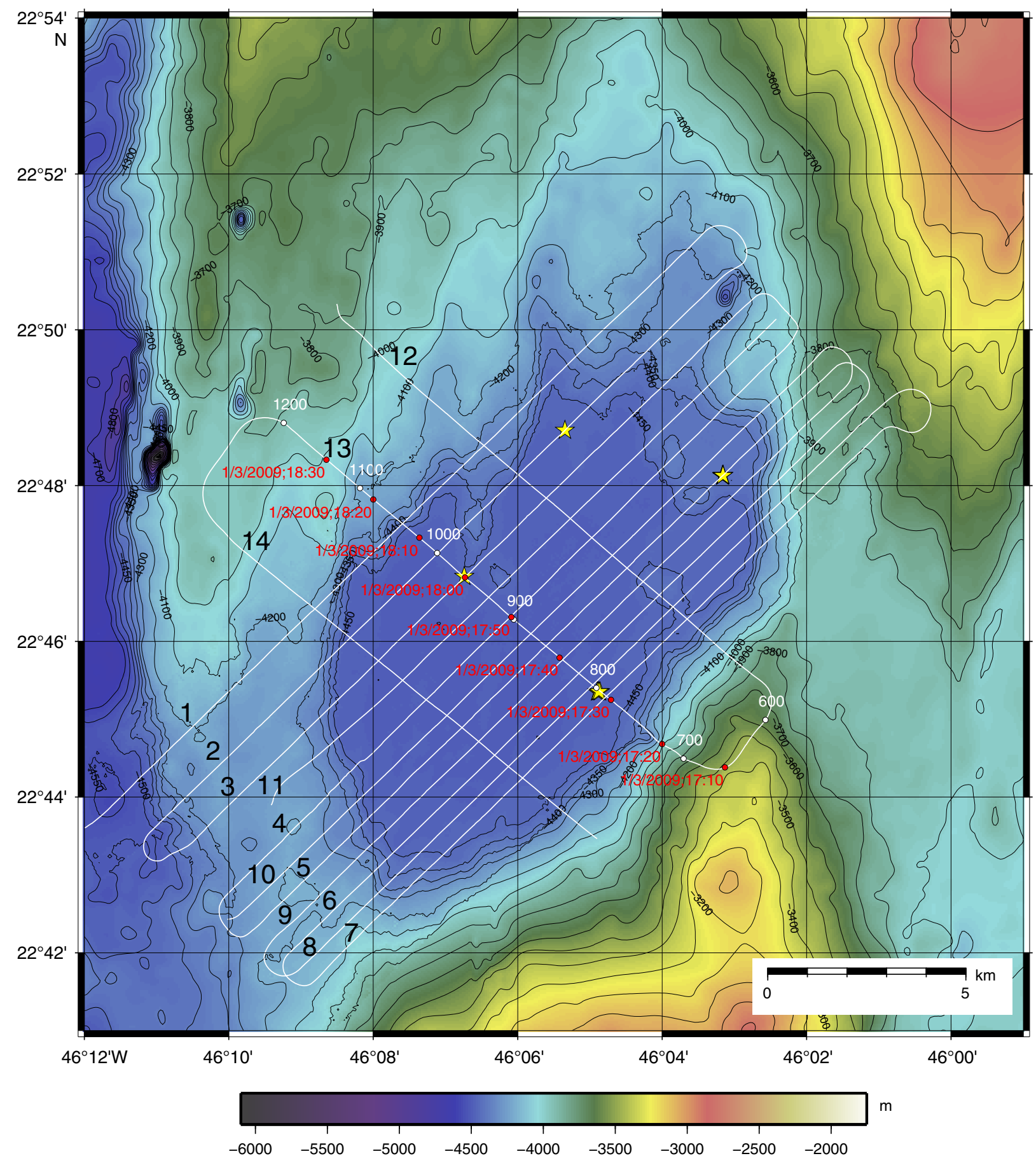


Figure AF38. Parasound record of Profile 13.

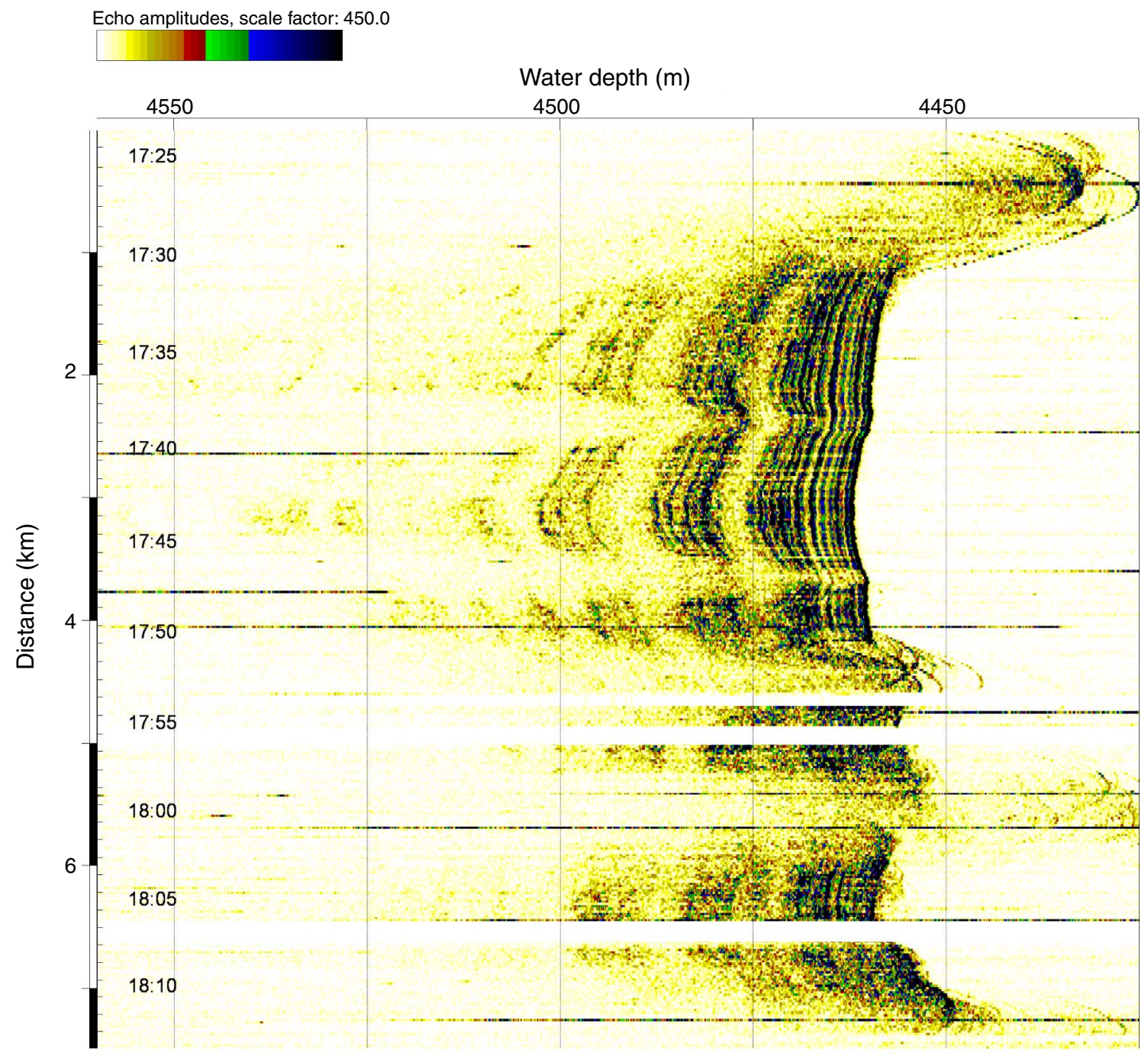


Figure AF39. Seismic record of Profile 13.

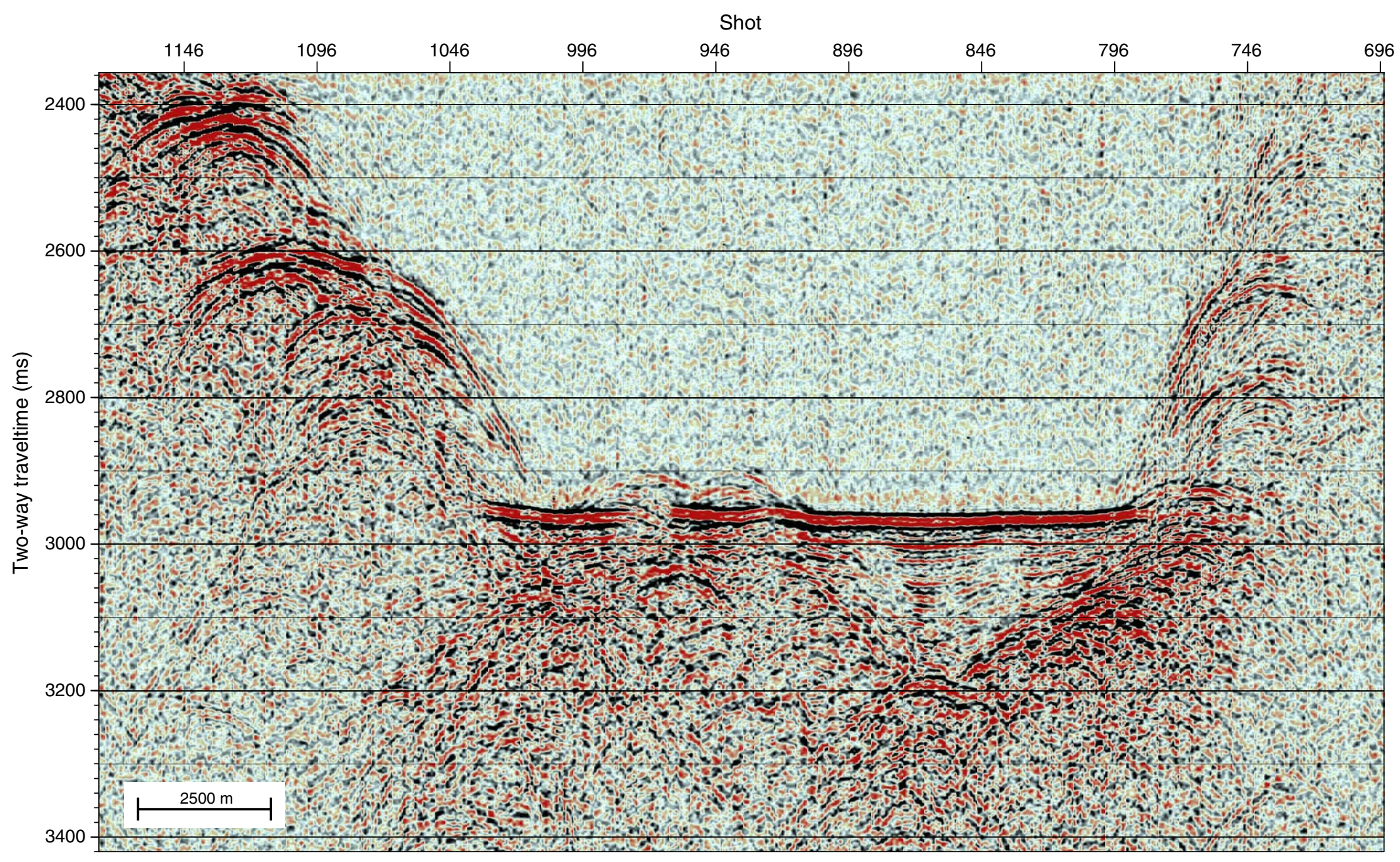


Figure AF40. Map showing shotpoint navigation for seismic and Parasound Profile 14. Stars = positions of DSDP, ODP, and IODP boreholes.

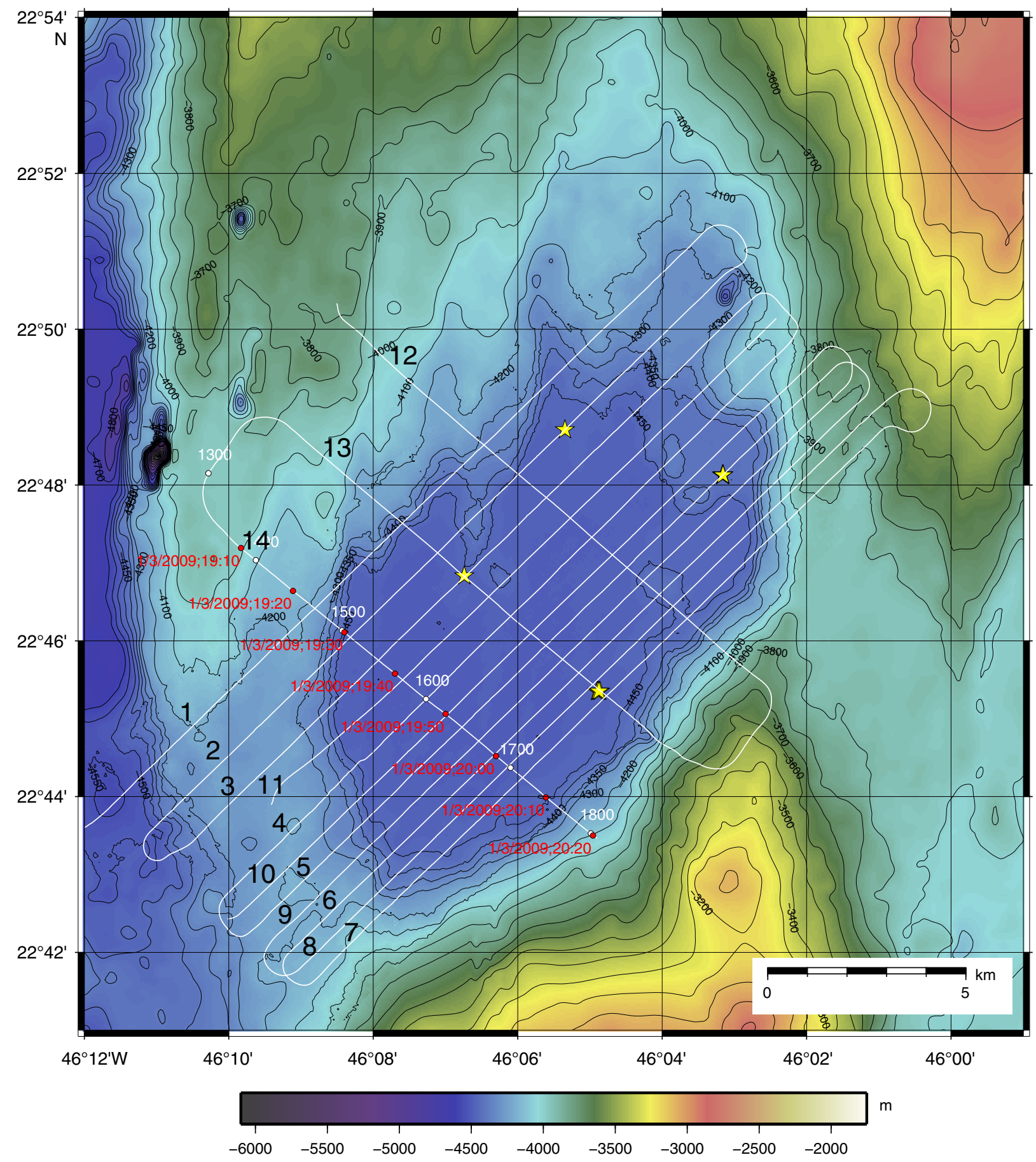


Figure AF41. Parasound record of Profile 14.

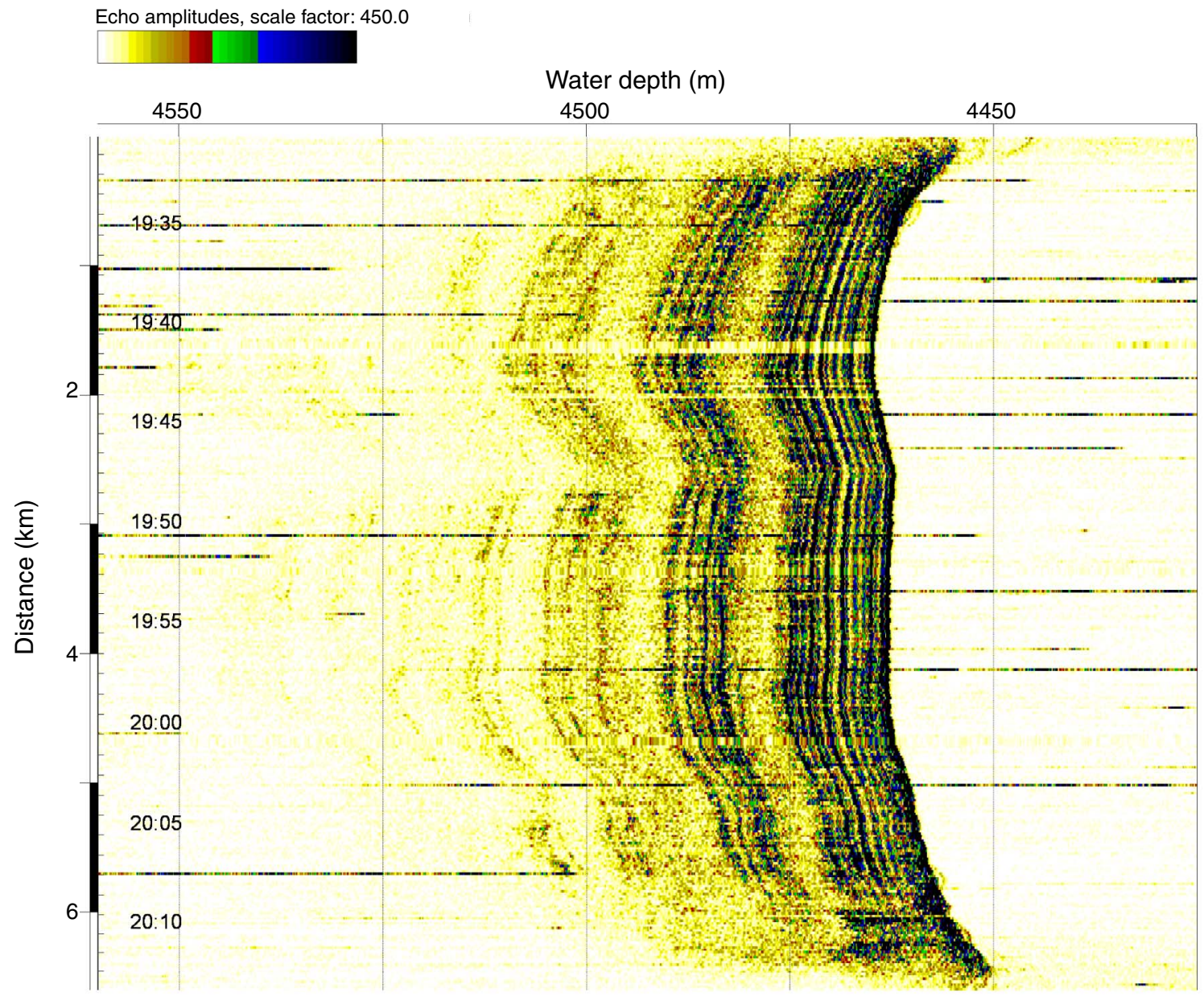


Figure AF42. Seismic record of Profile 14.

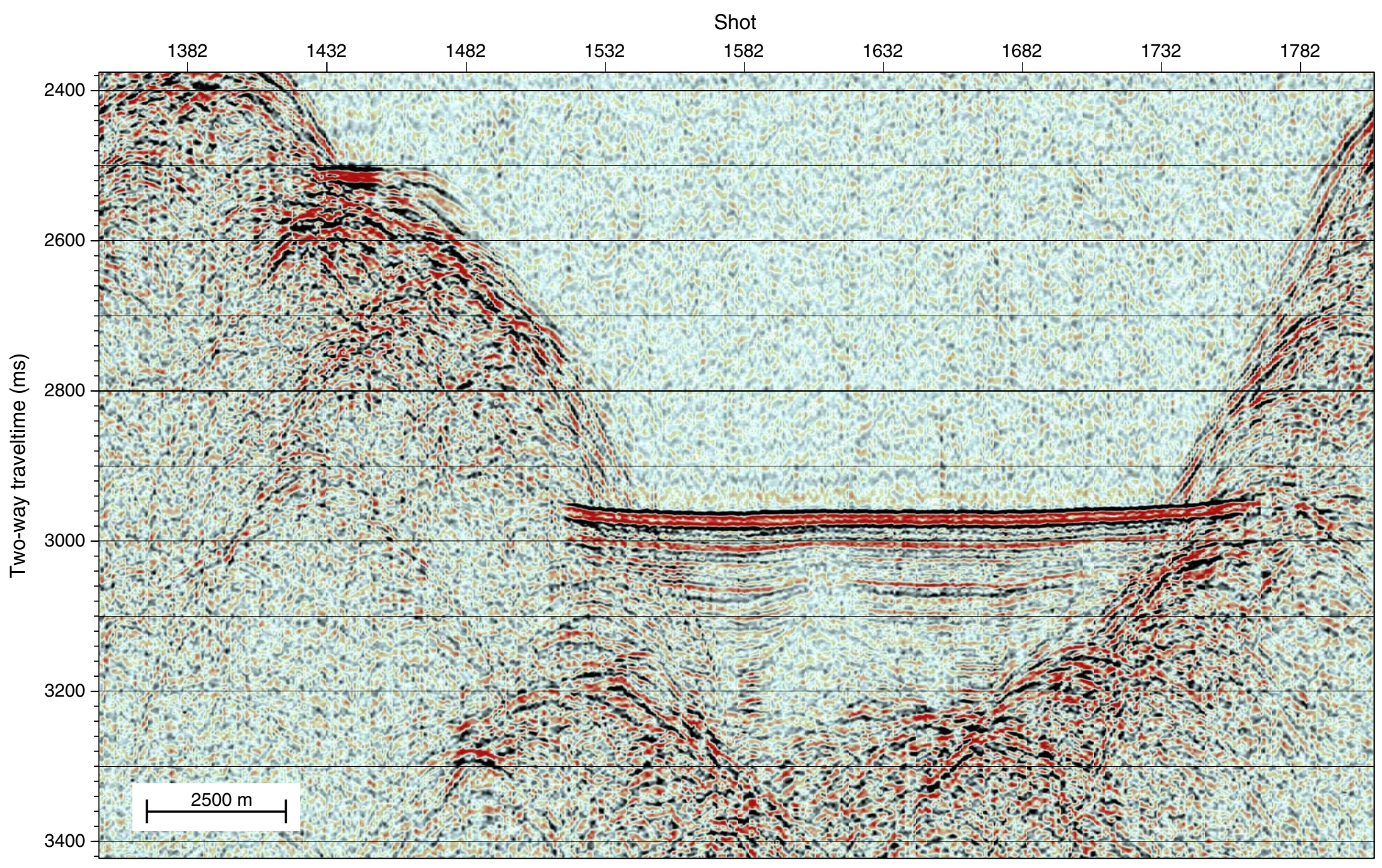

